\title{
The Ancestral Caddo Cemetery at the H. R. Taylor (41HS3) Site, Harrison County, Texas
}

Timothy K. Perttula

Follow this and additional works at: https://scholarworks.sfasu.edu/ita

Part of the American Material Culture Commons, Archaeological Anthropology Commons, Environmental Studies Commons, Other American Studies Commons, Other Arts and Humanities Commons, Other History of Art, Architecture, and Archaeology Commons, and the United States History Commons

Tell us how this article helped you.

This Article is brought to you for free and open access by the Center for Regional Heritage Research at SFA ScholarWorks. It has been accepted for inclusion in Index of Texas Archaeology: Open Access Gray Literature from the Lone Star State by an authorized editor of SFA ScholarWorks. For more information, please contact cdsscholarworks@sfasu.edu. 
The Ancestral Caddo Cemetery at the H. R. Taylor (41HS3) Site, Harrison County, Texas

\section{Creative Commons License}

\section{(c) (1) ()}

This work is licensed under a Creative Commons Attribution-NonCommercial 4.0 International License 


\section{The Ancestral Caddo Cemetery at the H. R. Taylor (41HS3) Site, Harrison County, Texas}

Timothy K. Perttula

\section{Introduction}

The H. R. Taylor site (41HS3) is an ancestral Caddo community cemetery in the lower reaches of the Big Cypress Creek basin in East Texas (Figure 1). The cemetery was used by Caddo peoples affiliated with the Late Caddo period Titus phase (ca. A.D. 1430-1680), probably between ca. A.D. 1600-1680, an archaeological construct. Its affiliation with a specific named Caddo group or tribe is not known, and by the early $18^{\text {th }}$ century much of the Big Cypress Creek basin was not inhabited by Caddo peoples, or peoples of any other American Indian group. The H. R. Taylor site is one of more than 146 Titus phase cemeteries, both family and community in organization and scope, identified from archaeological investigations over the last 100 years of the region's archaeological record and Titus phase mortuary practices (see Fields et al. 2014:405-433; Perttula 2012; Thurmond 1990).

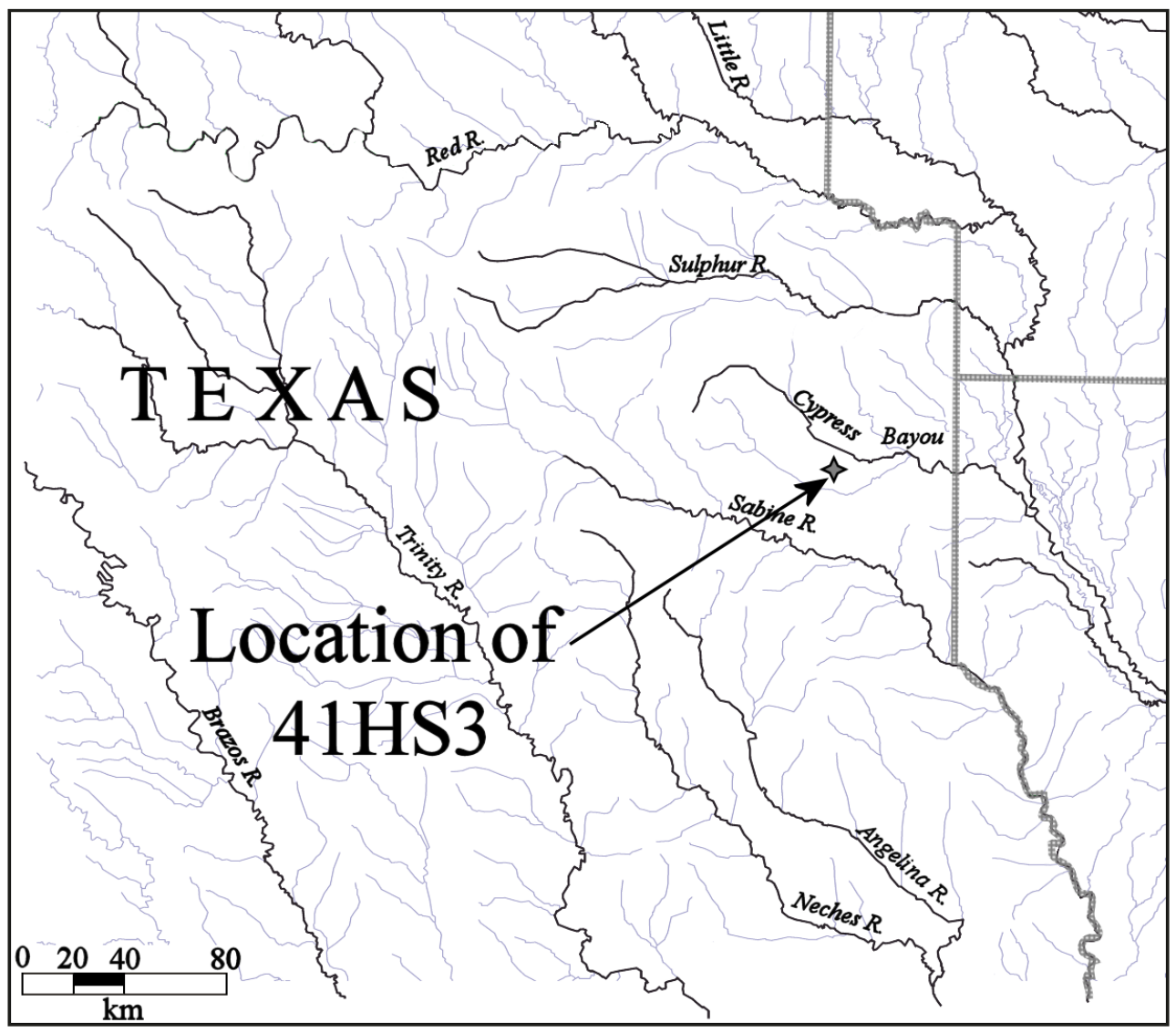

Figure 1. The location of the H. R. Taylor site (41HS3) in Harrison County in East Texas. 
The site and cemetery was found by a local landowner in 1929, and several burial features had been excavated by local collectors, but in the summer of 1931 University of Texas archaeologists began extensive excavations there (Pearce and Jackson 1931). Their excavations identified 64 ancestral Caddo burial features that contained a diverse set of funerary offerings to accompany the deceased to the Caddo's House of Death. The principal funerary offerings preserved in the burial features include ceramic vessels and arrow points, mainly of the distinctive Ripley Engraved, var. McKinney ceramic type and the Talco arrow point type. There were also ceramic pipes, ceramic ear spools and plugs, clay masses, celts, polished stones, red ochre chunks, and ground stone tools; undoubtedly there were organic remains (i.e., foods, baskets, mats, wood artifacts) placed in the burial features as well, but these have not preserved in the sandy burial feature fill.

Community cemeteries such as the H. R. Taylor site in Titus phase contexts tend to have more evidence of high-status elite burials than do family cemeteries. Nine percent (n-6) of the burials at the H. R. Taylor site have been identified by Fields et al. (2014:Table 7.14) as high status burials, compared to 18 percent at the generally contemporaneous Tuck Carpenter site (41CP5) community cemetery (Fields et al. 2014:Table 7-14). Higher proportions (22 percent), however, of elite high-status burials are present at the Pine Tree Mound site (41HS15) in the Sabine River basin (Fields and Gadus 2012), a number in large shaft tombs. The remainder of the burials at the sites would have been those of commoners, and they generally were not accompanied by high numbers or a diverse range of funerary offerings, and none of these burials would have been placed in shaft tombs.

This article begins with a consideration of the character of the ceramic vessel assemblage $(n=488)$ placed in the 64 burial features at the H. R. Taylor site. This includes a consideration of vessel form, temper use, vessel form by vessel ware, vessel size, distinctive attributes of the vessels, use of clay pigments, represented ceramic types, non-local vessels in the assemblage, and fine ware vessels with multiple motifs (i.e., on rim-body or upper-lower rim panels) (see also Perttula 2018). As mentioned above, other funerary offerings, including ceramic pipes $(n=5)$, ceramic ear spools $(n=2)$, ceramic ear plus $(n=2)$, arrow points $(n=213)$, ground stone celts $(n=9)$, other ground stone tools $(n=6)$, polished stones $(n=7)$, and one non-cortical piece of quartzite in one of the burial features are discussed in more detail in Perttula (2018:496-504). Next, I discuss the estimated age of the cemetery, which is challenging in the absence of radiocarbon dates from any of the burial features at the H. R. Taylor site, and conclude with an examination of the intra-cemetery spatial and temporal structure of the cemetery, its expansion in space and through time, and the intriguing distribution of funerary offerings in individual burial features across the cemetery.

\section{Ceramic Vessel Assemblage}

The most distinctive material culture item of the Caddo groups living in East Texas were the ceramics they made for cooking, storage, and serving needs, and also included as necessary funerary goods. The styles and forms of ceramics found on sites in the region, such as the H. R. Taylor site, hint at the variety, temporal span, and geographic extent of a number of ancestral Caddo groups spread across the landscape. The diversity in decoration and shape in Caddo ceramics is substantial, both in the utility ware jars and bowls, as well as in the fine ware bottles, carinated bowls, and compound vessels, and these characteristics are related to distinctive communities of identity and practice and the recognition of social networks and landscapes of practice from ceramic assemblages, where potters shared a group identity that can be reconstructed through the analysis of suites of technological and stylistic attributes (cf. Eckert et al. 2015:2; Worth 2017:137-139).

Caddo potters made ceramics in a wide variety of vessel shapes, employing distinctive technological traditions of temper choice, surface finishing techniques, and firing conditions, along with an abundance of well-crafted and executed body and rim designs and surface treatments. From the archaeological contexts in which Caddo ceramics have been found, as well as inferences about their manufacture and 
use, it is evident that ceramics were important to the Caddo in the cooking and serving of foods and beverages; in the storage of foodstuffs; as personal possessions; as works of art and craftsmanship (i.e., some vessels were clearly made to never be used in domestic contexts); and as social identifiers. Certain shared and distinctive stylistic motifs and decorative patterns marked closely related communities and constituent groups. Other motifs may have originally been more personal, perhaps deriving from body tattoo motifs.

The Caddo made both fine wares with engraved and slipped decorative elements, with burnished or polished surfaces, including bottles and many bowls of different forms, and utility wares with wet paste decorative elements (i.e., brushed, incised, punctated methods, etc.). These kinds of ceramics were designed to serve different purposes within Caddo communities and family groups - from that of a cooking pot to the mortuary function of a ceremonial beaker-and this is reflected in differences in paste, surface treatment, firing methods, decoration, and vessel form between the two wares. In general, vessels from the burial features at the H. R. Taylor site were fired in a reducing environment and cooled in the open air (or a high oxygen environment), with fire clouds on both interior and exterior vessel surfaces. Utility ware vessels were also typically smoothed on the interior surface, while fine ware bowls, carinated bowls, and compound bowls were smoothed or burnished on both vessel surfaces; bottles tended to be smoothed or burnished only on the exterior vessel surface.

Decorations and slips, both red (Hatinu) and black (hadikuh) were added before, as well as after, baking in an open fire, and commonly the vessels were then burnished and polished. Furthermore, red ochre and white (hakaayuh) kaolinite clay pigments were often added to the decorations on bottles and carinated bowls; green (hasahkuh) pigments have also been documented on some engraved vessels (see Fields and Gadus 2012:Table 6-3).

\section{Vessel Form}

The 488 ceramic vessels in UT excavated burial features at the H. R. Taylor site are from a variety of vessel forms (Table 1). Carinated bowls, jars, and bottles are the three most common vessel forms, and together these comprise 90.0 percent of all the vessels in the burial features, with carinated bowls alone representing 43.1 percent of the documented vessel assemblage. Bowls and compound bowls represent another 8.6 percent of the vessel assemblage, followed by the truly rare forms: ollas, deep bowls, and a conjoined carinated bowl-bowl; these latter three vessel forms account for only 1.4 percent of the vessel assemblage, and occur in only a few burial features.

Table 1. Ceramic vessel forms in burial features at the H. R. Taylor site.

\begin{tabular}{lll}
\hline Form & Number & Percentage \\
\hline Carinated bowl & 210 & 43.1 \\
Jar & 158 & 32.4 \\
Bottle & 71 & 14.6 \\
Bowl & 23 & 4.7 \\
Compound bowl & 19 & 3.9 \\
Olla & 5 & 1.0 \\
Deep Bowl & 1 & 0.2 \\
Conjoined vessel & 1 & 0.2 \\
\hline Totals & 488 & 100.0 \\
\hline
\end{tabular}




\section{Use of Temper}

A variety of temper inclusions were used for the manufacture of the ceramic vessels placed as offerings in the burial features at the H. R. Taylor site (Table 2). The principal temper is grog (i.e., crushed vessel sherds), which comprises 68.7 percent of all the vessels. The use of grog temper as the sole aplastic is best represented in the bowls (90.9 percent) and ollas ( 80.0 percent). Another 18.8 percent of the vessels have both grog and burned bone temper. The vessel forms with the highest proportions of grog-bone temper use are the compound bowls (31.6 percent) and bottles (19.7 percent). Approximately 90 percent of the vessels in the assemblage have grog temper, either as the sole temper or in association with bone and/or crushed pieces of hematite. The sole use of bone as a temper in vessel manufacture is represented in 8.0 percent of the vessels; these are best represented in the carinated bowls (10.5 percent), and the one conjoined vessel was made with bone temper. More than 27 percent of the H. R. Taylor vessels have bone temper, either as the sole temper or in association with grog and/or hematite.

Table 2. Tempers used in the manufacture of the ceramic vessels at the H. R. Taylor site.

\begin{tabular}{lllllllll}
\hline Vessel form & G & G-B & B & Sh & G-H & B-H & G-H-B & N \\
\hline Carinated bowl & 141 & 39 & 22 & 2 & 3 & 2 & 1 & 210 \\
Jar & 110 & 30 & 9 & 2 & 5 & 1 & 1 & 158 \\
Bottle & 50 & 14 & 5 & 1 & 1 & - & - & 71 \\
Bowl & 20 & 2 & 1 & - & 1 & - & - & 22 \\
Compound bowl & 10 & 6 & 1 & - & 2 & - & - & 19 \\
Olla & 4 & 1 & - & - & - & - & - & 5 \\
Deep bowl & - & - & - & 1 & - & - & - & 1 \\
Conjoined vessel & - & - & 1 & - & - & - & - & 1 \\
\hline Totals & 335 & 92 & 39 & 6 & 11 & 3 & 2 & 488 \\
\hline
\end{tabular}

G=grog; G-B=grog-bone; $\mathrm{B}=$ bone; $\mathrm{Sh}=$ shell; $\mathrm{G}-\mathrm{H}=$ grog-hematite; $\mathrm{B}-\mathrm{H}=$ =bone-hematite; $\mathrm{G}-\mathrm{H}-\mathrm{B}=$ grog-hematite-bone

About 3.3 percent of the vessels have crushed pieces of hematite in their paste, in addition to grog and/or bone temper (see Table 2). Most of these occur in the compound bowls (10.5 percent of these vessels), jars (4.4 percent), and bowls (4.5 percent).

There are only six shell-tempered vessels in the vessel assemblage from the burial features (see Table 3 ), accounting for 1.2 percent of the assemblage. These vessels were not locally manufactured, but had been obtained from Caddo potters of the Belcher and McCurtain phase communities that lived along the Red River in Northwestern Louisiana, southwestern Arkansas, and along the mid-Red River in East Texas and Southeast Oklahoma (see Perttula et al. 2012; Selden et al. 2014:Figure 4). Represented in the shell-tempered wares are a Hodges Engraved bottle, a Foster Trailed-Incised jar, a Glassell Engraved carinated bowl, a Simms Engraved carinated bowl, a Bowie Engraved deep bowl, and a Karnack Brushed-Incised, var. Karnack jar.

\section{Vessel Form by Vessel Ware}

In the assemblage as a whole, 67.1 percent of the vessels from burial features at the H. R. Taylor site are from fine wares that have engraved and/or red-slipped decorative elements. This includes all of the bottles, compound bowls, ollas, deep bowls, and the one conjoined carinated bowl-bowl, as well as 95.2 percent of the carinated bowls (Table 3) and 82.6 percent of the bowls. By contrast, utility wares (i.e., decorated with wet paste elements, including appliqued, brushed, incised, punctated, etc.) include 91.8 percent of the jars in the assemblage, and 13.0 percent of the bowls. Overall, 30.0 percent of the vessels 
left as funerary offerings are from utility wares. Plain wares are present only among the carinated bowls, jars, and bowls, but they represent only between 3.2-4.3 percent of the vessels with these forms. Less than 3 percent of the vessel assemblage from the H. R. Taylor site are plain wares (Table 3).

Table 3. Vessel form by vessel ware in the H. R. Taylor vessel assemblage.

\begin{tabular}{lllll}
\hline Vessel Form & Fine ware & Utility ware & Plain ware & $\mathrm{N}$ \\
\hline Carinated bowl & $95.2^{*}$ & - & 3.8 & 210 \\
Jar & 6.3 & 91.8 & 3.2 & 158 \\
Bottle & 100.0 & - & - & 71 \\
Bowl & 82.6 & 13.0 & 4.3 & 23 \\
Compound bowl & 100.0 & - & - & 19 \\
Olla & 100.0 & - & - & 5 \\
Deep bowl & 100.0 & - & - & 1 \\
Conjoined vessel & 100.0 & - & -14 & 488 \\
\hline Totals & 326 & 148 & 2.9 & \\
Percentage & 67.1 & 30.0 & & \\
\hline
\end{tabular}

*percentage

\section{Vessel Size}

The different vessel forms occur in a variety of sizes, undoubtedly because of different purposes the vessels had both in life and in death as accompaniments of the deceased Caddo on the six-day journey to the House of Death. Carinated bowls are individually sorted into five groups, from very small, small, medium, large, and very large in size (Figure 2); these latter vessels, although rare, would have held more than 4 liters of contents. The majority of the carinated bowls range from small to large in size.

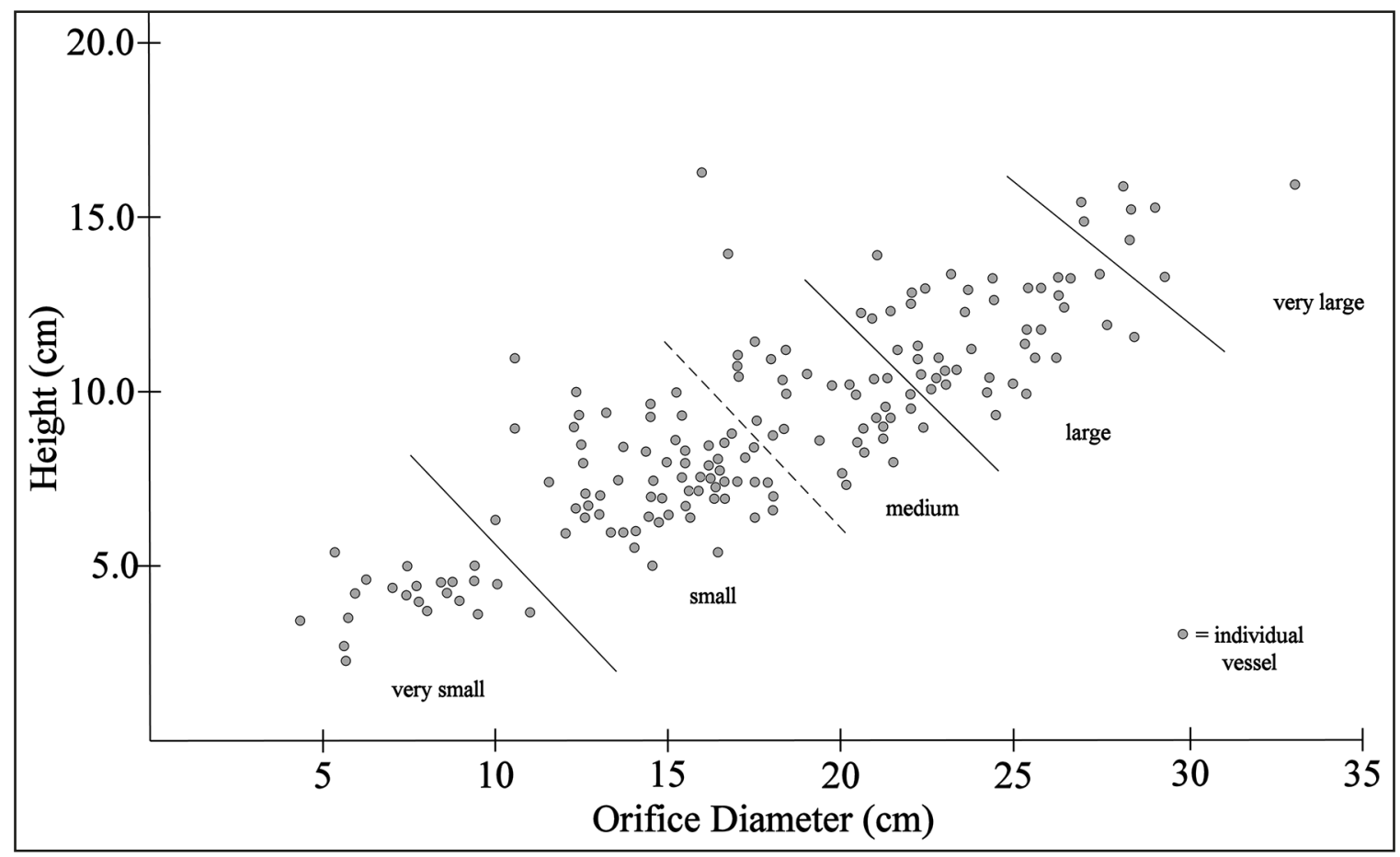

Figure 2. Height and orifice diameter measurements for carinated bowls in burial features at the H. R. Taylor site. 
There are five size groups of jars, with the Group II vessels (ranging from ca. 0.5 liters to ca. 2.2 liters in volume) most common (Figure 3). Large and very large jars are present, and these have volumes ranging from ca. 9 liters to as much as 24.5 liters.

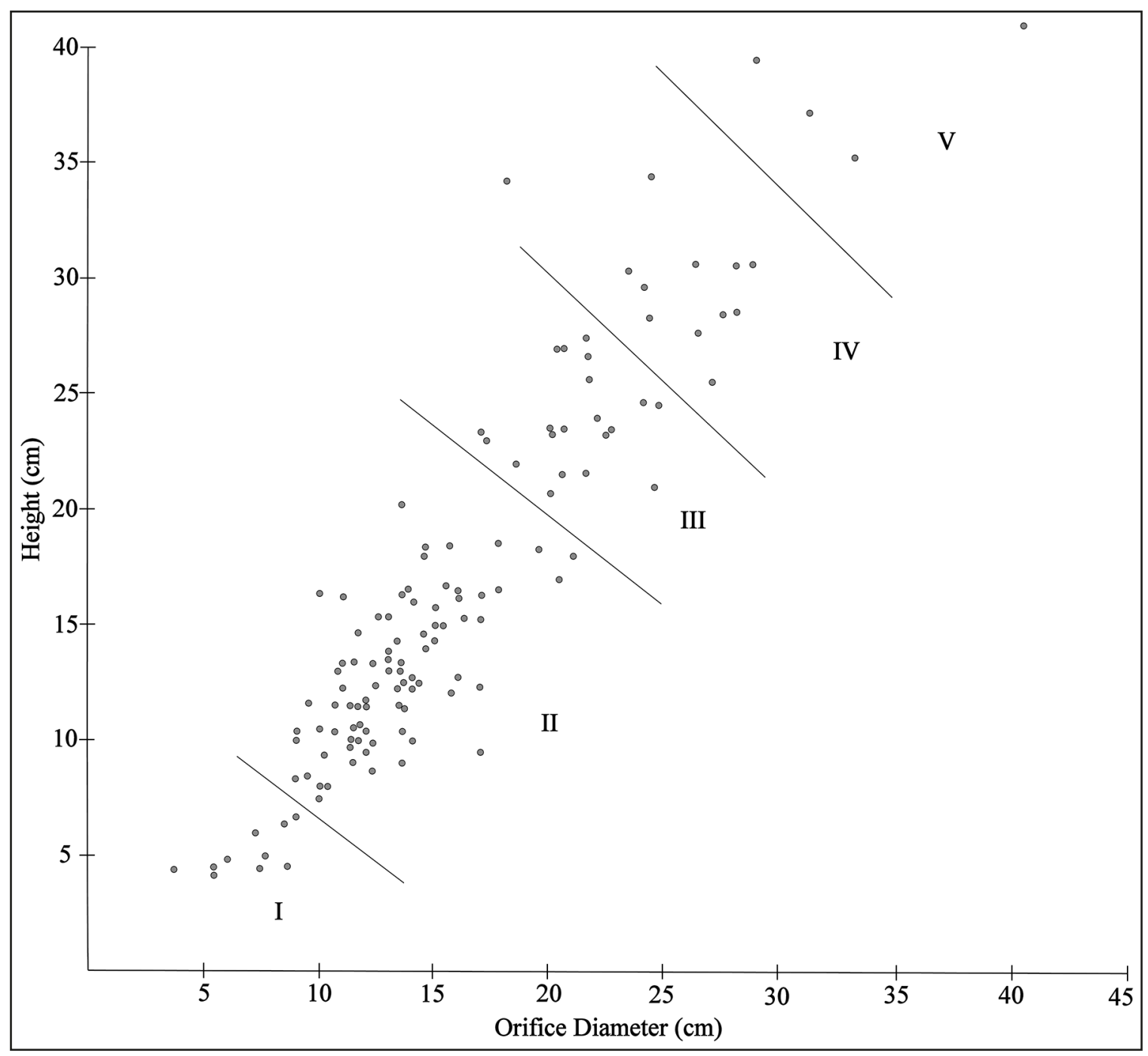

Figure 3. Height and orifice diameter measurements for jars in burial features at the H. R. Taylor site.

The bottles placed as funerary offerings can be divided into four size groups, from very small to very large (Figure 4). Most fall into size groups II and III, with volumes of ca. 0.3 to 0.9 liters, and having heights that range from $8.0-18.0 \mathrm{~cm}$ and maximum body diameters that range from $6-14 \mathrm{~cm}$.

Bowls can be placed into three groups, from very small to moderate in size (Figure 5); the one deep bowl is larger than all the other bowls. The bowls most commonly range from 3-7 $\mathrm{cm}$ in height and 6-14 $\mathrm{cm}$ in orifice diameter. Compound bowls fall into three size groupings, and almost all of them range from very small to moderate in size (Figure 6). One very large compound bowl, more than 7.5 liters in volume, is in the assemblage.

Finally, the ollas in the vessel assemblage from the H. R. Taylor site have two size groups, moderate to large in size (Figure 7). These vessels range from $15-33 \mathrm{~cm}$ in height and $9-11 \mathrm{~cm}$ in orifice diameter. 


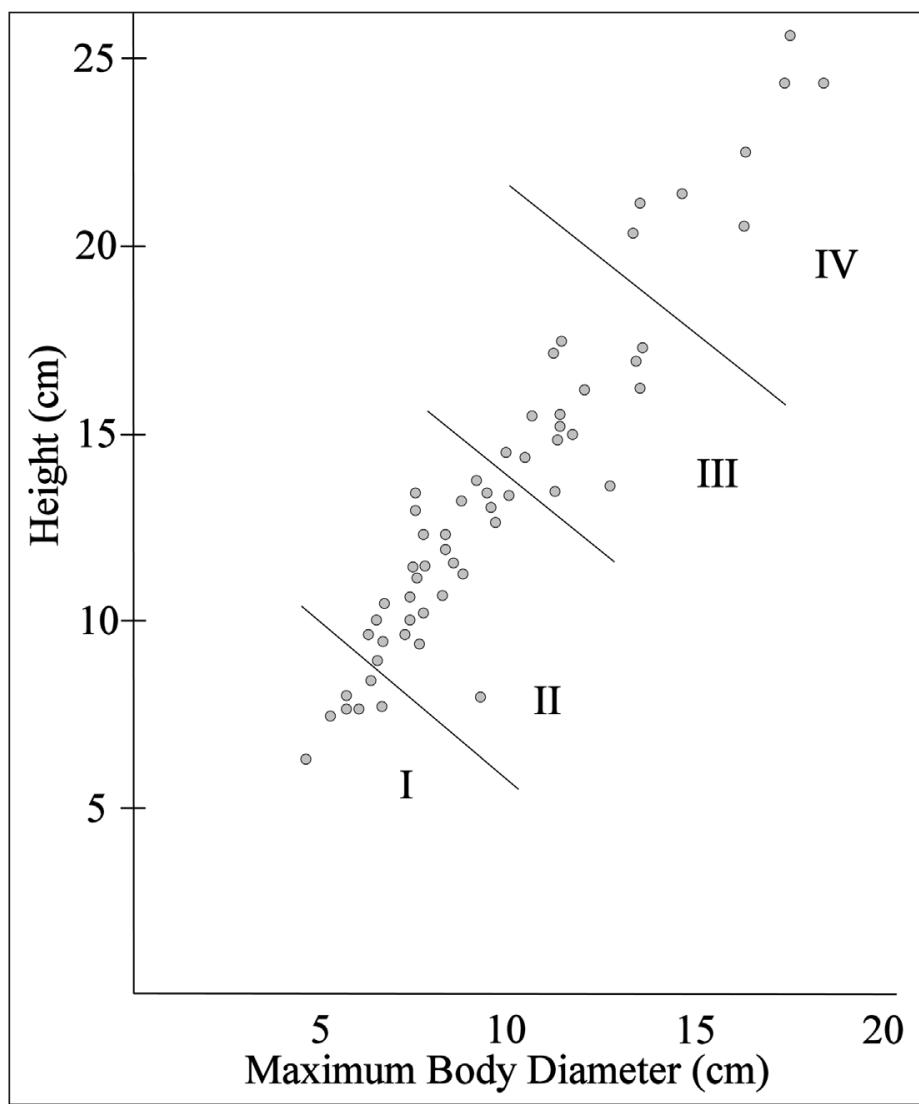

Figure 4. Height and maximum body diameter measurements for bottles in burial features at the H. R. Taylor site.

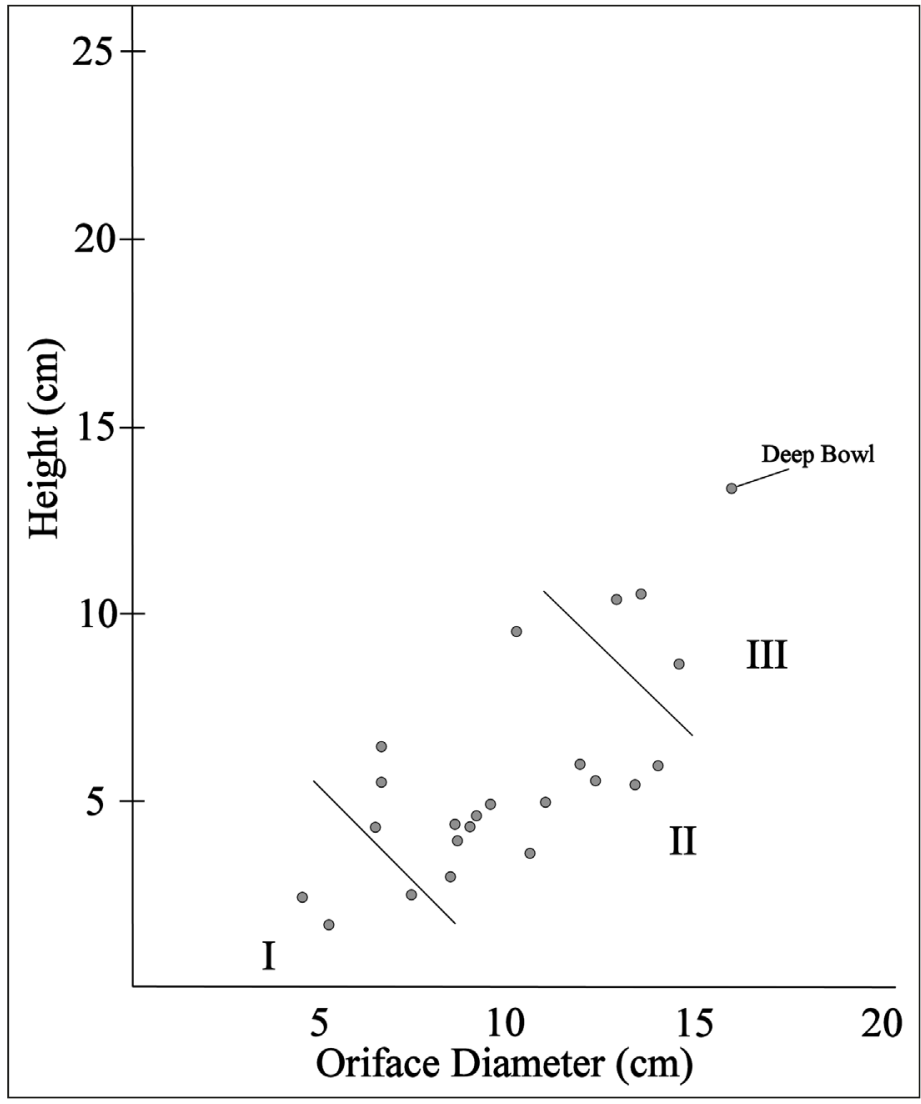

Figure 5. Height and orifice diameter measurements for bowls in burial features at the H. R. Taylor site. 


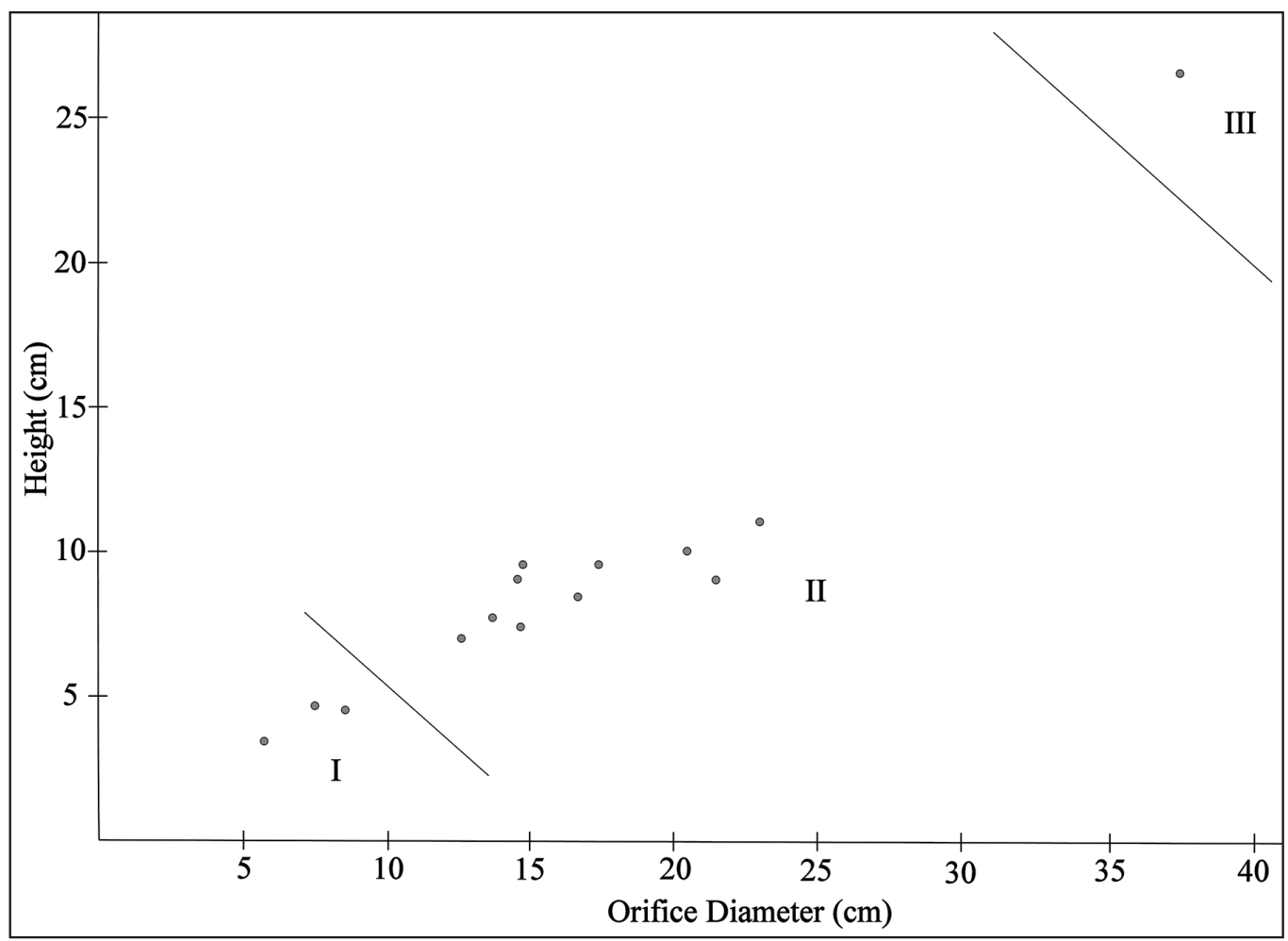

Figure 6. Height and orifice diameter measurements for compound bowls in burial features at the H. R. Taylor site.

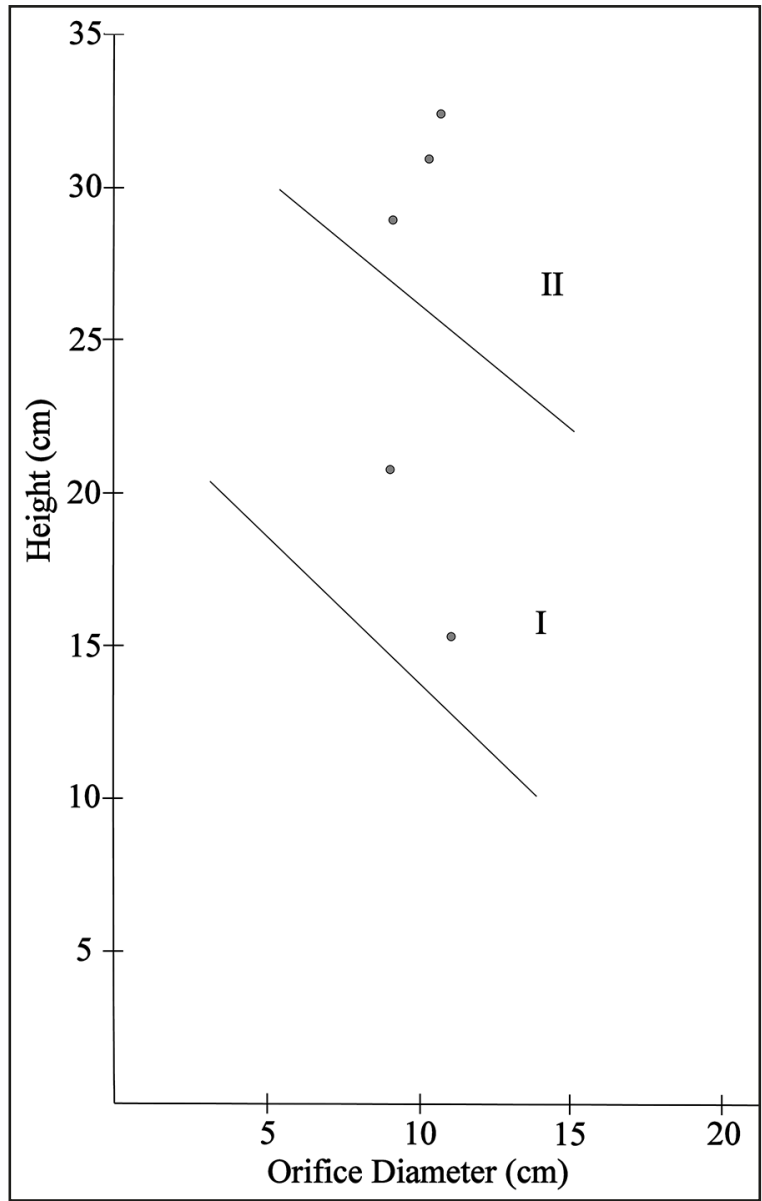

Figure 7. Height and orifice diameter measurements for ollas in burial features at the H. R. Taylor site. 
One of the more distinctive characteristics of the H. R. Taylor vessel assemblage is the number of very small to miniature vessels that occur in burial features. More than 37.0 percent of the burial features $(n=24)$ have miniature vessels as funerary offerings, ranging from one vessel per burial $(n=15)$, to two miniature vessels $(n=4)$, three miniature vessels $(n=1)$, and then four miniature vessels $(n=4)$. None of the burials at the site have only miniature vessels - as might be expected in a child's burial - and it is likely that these vessels were used to hold clay pigments, powders, and other special contents for use by certain numbers of the deceased, including those of high-status burials. Four of the high-status burials have miniature vessels, including Burial A-47 (Group 4), Burial A-54 (Group 4), Burial A-45 (Group 5), and Burial A-46 (Group 5).

Nine percent of the ceramic vessels in the assemblage are miniature vessels: 10.7 percent of the fine wares, 4.1 percent of the utility wares, and 21.4 percent of the plain wares (Table 4). In the fine wares, miniature vessels are proportionally most common among the fine ware bowls, compound bowls, and bottles, plain bowls, and utility ware jars.

Table 4. Miniature vessels by vessel forms and wares.

\begin{tabular}{lllll}
\hline Vessel form & Fine ware & Utility ware & Plain ware & $\mathrm{N}$ \\
\hline Carinated bowl & $16 / 7.6 \%$ & - & $1 / 0.5 \%$ & 210 \\
Jar & $2 / 1.3 \%$ & $6 / 3.8 \%$ & $1 / 0.6 \%$ & 158 \\
Bottle & $10 / 14.1 \%$ & - & - & 71 \\
Bowl & $4 / 17.4 \%$ & - & $1 / 4.3 \%$ & 23 \\
Compound bowl & $3 / 15.8 \%$ & - & - & 19 \\
\hline Totals & $35 / 10.7 \%$ & $6 / 4.1 \%$ & $3 / 21.4 \%$ & 488 \\
\hline
\end{tabular}

\section{Distinctive Vessel Attributes}

There are a number of other distinctive attributes of the different vessel forms among the ceramic funerary offerings (Table 5). Among the carinated bowls, the principal distinctive attribute is an inverted rim profile; most carinated bowls in the assemblage have a direct rim profile. Many of the vessels with an inverted rim profile are of the Taylor Engraved type $(n=17)$, as well as Ripley Engraved, Simms Engraved, Glassell Engraved, and several plain ware vessels; the one conjoined Ripley Engraved-Taylor Engraved vessel also has an inverted rim. The other carinated bowl attributes occur on Ripley Engraved vessels, while the globular carinated bowl form is represented by two vessels (a plain ware and a Poynor Engraved vessel) that probably originated among vessels made by Caddo groups in the upper Neches River basin.

Table 5. Distinctive vessel form attributes for H. R. Taylor vessels.

\begin{tabular}{lll}
\hline Vessel Form & Distinctive attribute & No./Percent \\
\hline Carinated bowl & inverted rim & $45 / 21.4 \%$ \\
& lip tabs & $1 / 0.5 \%$ \\
& rim peaks & $1 / 0.5 \%$ \\
& exterior thickened & $1 / 0.5 \%$ \\
& globular form & $2 / 1.0 \%$
\end{tabular}


Table 5. Distinctive vessel form attributes for H. R. Taylor vessels, cont.

\begin{tabular}{lll}
\hline Vessel Form & Distinctive attribute & No./Percent \\
\hline Jar & incised lip & $1 / 0.6 \%$ \\
& lug handles & $13 / 8.2 \%$ \\
& strap handles & $2 / 1.3 \%$ \\
& rim peaks & $20 / 12.7 \%$ \\
& suspension holes & $2 / 1.3 \%$ \\
& collared rim & $2 / 1.3 \%$ \\
& scalloped lip & $1 / 0.6 \%$ \\
& lip tabs & $1 / 0.6 \%$ \\
Bottle & cut-down vessel & $2 / 1.3 \%$ \\
& carinated body & $5 / 7.0 \%$ \\
& collar at base of neck & $2 / 2.8 \%$ \\
& covered orifice & $1 / 1.4 \%$ \\
& spool neck & $3 / 4.2 \%$ \\
Bowl & pedestalled base & $2 / 2.8 \%$ \\
& tab tails & $1 / 1.4 \%$ \\
& suspension hole & $1 / 4.3 \%$ \\
Conjoined Vessel & inverted rim & $1 / 4.3 \%$ \\
& 3-sided form & $1 / 4.3 \%$ \\
& rim peaks & $3 / 13.0 \%$ \\
& effigy bowl form & $2 / 8.7 \%$ \\
& rim peaks & $5 / 26.3 \%$ \\
& lip tabs & $1 / 5.3 \%$ \\
& inverted rim & $1 / 100 \%$ \\
\hline
\end{tabular}

The most distinctive attributes among the jars are rim peaks and lug handles, often together on the same vessel (see Table 5) of the Harleton Appliqued type. Lip tabs and strap handles are also present on Harleton Appliqued jars, and one Karnack Brushed-Incised vessel has an incised lip.

Bottles of several different types have a carinated body; the majority of the bottles at the H. R. Taylor site have globular bodies. Single Keno Trailed, Taylor Engraved, and Hodges Engraved bottles have spool necks, two Taylor Engraved bottles have pedestalled bases (see Suhm and Jelks 1962:Plate 76d-e, i), and one Hodges Engraved bottle has appliqued tab tails (see Table 5).

Among the bowls, the most distinctive attribute is rim peaks, mainly on Ripley Engraved vessels, and effigy bowls (see Table 5). At least one of the effigy bowls is an upper Neches River basin Hood Engraved, var. Hood vessel (Perttula 2011:Figure 6-67). Single Taylor Engraved, Simms-Taylor, and Ripley Engraved bowls have respectively suspension holes, an inverted rim, and a three-sided form.

\section{Use of Clay Pigments}

Red or white clay pigments were used by the Caddo potters in the H. R. Taylor community. Approximately 10 percent of the fine ware vessels in the assemblage have a clay pigment as a vessel embellishment, mostly a white pigment $(n=23,72$ percent); vessels with a red pigment comprise 28 percent of the fine wares with pigment. 
Fine ware carinated bowls and compound bowls have the highest proportion of vessels with pigment in the vessel assemblage: 11.4 percent among the carinated bowls and 10.5 percent of the compound bowls (Table 6). A white clay pigment was clearly preferred for these vessel forms. Seven percent of the fine ware bottles have a clay pigment rubbed in the engraved lines, and red was the preferred pigment color. Only 5.3 percent of the bowls in the assemblage have a clay pigment, and a white pigment was chosen.

Table 6. Pigments by fine vessel forms at the H. R. Taylor site.

\begin{tabular}{llll}
\hline Vessel form & white pigment & red pigment & N \\
\hline Carinated bowl & 19 & 5 & 24 \\
Compound bowl & 2 & - & 2 \\
Bottle & 1 & 4 & 5 \\
Bowl & 1 & - & 1 \\
\hline Totals & 23 & 9 & 32 \\
\hline
\end{tabular}

Among the fine wares, pigment use is quite common on Ripley Engraved vessels, particularly the use of white pigment on Ripley Engraved, var. McKinney carinated bowls (Table 7). Red pigment is well represented in Taylor Engraved carinated bowls and Wilder Engraved, var. unspecified bottles. Only vessels from three of the types and varieties had evidence of both white or red pigment use: Bailey Engraved, Ripley Engraved, var. Carpenter, and Taylor Engraved, var. Taylor.

Table 7. Pigment use among defined fine ware ceramic types at the H. R. Taylor site.

\begin{tabular}{|c|c|c|c|c|}
\hline Type & Vessel form & $\begin{array}{l}\text { White } \\
\text { pigment }\end{array}$ & $\begin{array}{l}\text { Red } \\
\text { pigment }\end{array}$ & $\mathrm{N}$ \\
\hline Bailey Engraved & $\mathrm{Bt}$ & 1 & $1^{*}$ & 2 \\
\hline Belcher Engraved & $\mathrm{CB}$ & 1 & - & 1 \\
\hline $\begin{array}{l}\text { Belcher Engraved-Ripley, } \\
\text { var. Pilgrims }\end{array}$ & $\mathrm{CPB}$ & 1 & - & 1 \\
\hline Hodges Engraved & $\mathrm{Bt}$ & - & 1 & 1 \\
\hline Ripley, var. Carpenter & $\mathrm{CB}$ & 2 & 1 & 3 \\
\hline Ripley, var. Cash & $\mathrm{CB}$ & 1 & - & 1 \\
\hline Ripley, var. McKinney & $\mathrm{CB}$ & $10^{*}$ & - & 10 \\
\hline $\begin{array}{l}\text { Ripley, var. McKinney- } \\
\text { Enis Smith }\end{array}$ & $\mathrm{CB}$ & - & 1 & 1 \\
\hline Ripley, var. Pilgrims & $\mathrm{CB}$ & 1 & - & 1 \\
\hline Ripley, var. Pilgrims & $\mathrm{CPB}$ & 1 & - & 1 \\
\hline Ripley, var. Williams & $\mathrm{CB}$ & 1 & - & 1 \\
\hline Ripley, var. unspecified & BW & 1 & - & 1 \\
\hline Ripley, var. unspecified & $\mathrm{CB}$ & 1 & - & 1 \\
\hline
\end{tabular}


Table 7. Pigment use among defined fine ware ceramic types at the H. R. Taylor site, cont.

\begin{tabular}{lllll}
\hline Type & Vessel form & $\begin{array}{l}\text { White } \\
\text { pigment }\end{array}$ & $\begin{array}{l}\text { Red } \\
\text { pigment }\end{array}$ & $\mathrm{N}$ \\
\hline Simms Engraved & $\mathrm{CB}$ & 1 & - & 1 \\
Taylor, var. Taylor & $\mathrm{CB}$ & 1 & 1 & 2 \\
Taylor, var. unspecified & $\mathrm{CB}$ & - & 2 & 2 \\
Wilder, unspecified & $\mathrm{Bt}$ & - & 2 & 2 \\
\hline
\end{tabular}

$\mathrm{Bt}=$ bottle; $\mathrm{CB}=$ carinated bowl $\mathrm{CPB}=$ compound bowl; $\mathrm{BW}=$ bowl

*including one miniature vessel

For comparative purposes, I compiled information on the use of clay pigments in several Early Caddo, Middle Caddo, Late Caddo, and Historic Caddo period ceramic vessel assemblages in East Texas. This includes the Middle Caddo period Washington Square Mound and Sanders sites (Perttula et al. 2010, 2016); the Pine Tree Mound and Mockingbird Late Caddo, Titus phase, sites (Fields and Gadus 2012; Perttula et al. 1998), Late Caddo vessel sherds from the Hatchel site (41BW3) (Perttula 2017), Late Caddo Frankston phase vessels from the upper Neches River basin (Perttula 2011), and Historic Caddo vessel assemblages at the Goode Hunt and Clements sites (Perttula 2015).

About 27 percent of the engraved vessels from Early Caddo period features at the George C. Davis site (41CE19) on the Neches River have clay pigments rubbed in engraved decorative elements. Of these vessels, 86 percent have a red clay pigment; the red pigment was clearly preferred by the Caddo potters at the George C. Davis site, particularly on Holly Fine Engraved vessels (Perttula 2016). The red clay pigment was added to one Hickory Engraved jar, two Holly Fine Engraved bottles, two Holly Fine Engraved bowls, and one Holly Fine Engraved carinated bowl. The one vessel with a white clay pigment in the assemblage is a Holly Fine Engraved bottle.

In the case of the Middle Caddo period vessel assemblages, about 21 percent of the engraved vessels at each site had a clay pigment rubbed in the engraved lines. Between 60-75 percent of these vessels have a red pigment (Table 8). At the Washington Square site, bottles and carinated bowls have red pigment, while the white pigment was applied to the engraved lines of two compound bowls (Perttula et al. 2010). Carinated bowls and bowls at the Sanders site have a red clay pigment, and one carinated bowl has a white clay pigment (Perttula et al. 2016).

Table 8. Clay pigment use in a sample of ancestral Caddo sites in East Texas, including the H. R. Taylor site.

Site Red pigment $\quad$ White pigment

Early Caddo period

George C. Davis (41CE19)

Middle Caddo period

Sanders (41LR2)

Washington Square (41NA49) 
Table 8. Clay pigment use in a sample of ancestral Caddo sites in East Texas, including the H. R. Taylor site, cont.

\begin{tabular}{lll}
\hline Site & Red pigment & White pigment \\
\hline Late Caddo period & & \\
Hatchel, ca. A.D. 1450/1500-1600 & 120 & 196 \\
Hatchel, ca. A.D. 1600-1691 & 9 & 4 \\
Pine Tree Mound (41HS15) & 21 & 24 \\
Mockingbird (41TT550) & 1 & 19 \\
H. R. Taylor (41HS3) & 9 & 23 \\
Upper Neches, A.D. 1400-1560 & 37 & 3 \\
Upper Neches, A.D. 1560-1680 & 4 & 7 \\
Historic Caddo period & & 3 \\
Goode Hunt/Clements (41CS23/ & 12 & \\
41CS25) & & \\
\hline
\end{tabular}

The use of clay pigments by zone and temporal periods at the Hatchel site was not consistent, but changed through time. Red pigments were most commonly used after ca. A.D. 1600, as 69 percent of the sherds with pigment had a red clay pigment (see Table 8). In the earliest platform zones, dated ca. A.D. 1450-1550, about 53 percent of the sherds with pigment in the assemblages had a red clay pigment. Conversely, between ca. A.D. 1550-1600, sherds with a red clay pigment comprise only 36 percent of the assemblages. The use of a white kaolin clay pigment peaked between ca. A.D. 1500-1600, as 64 percent of the sherd sample with pigment had the white pigment smeared in the engraved lines. The use of white clay pigment dropped to 31 percent after ca. A.D. 1600.

At the Pine Tree Mound site, pigment use in the engraved fine wares was quite common, as 56 percent of the engraved vessels had an applied pigment (Fields and Gadus 2012:Table 6-3). Although pigment use was rather equally spread between the red and white clay pigments in the vessel assemblage, unlike the other assemblages discussed in the text except for the ca. A.D. 1450-1500 deposits at the Hatchel platform mound, almost all the bottles (86 percent) had a red clay pigment, while 93 percent of the carinated bowls and 89 percent of the compound bowls had the white clay pigment, one of the highest proportion of white clay pigment use in these vessel forms in the East Texas ceramic assemblages under consideration herein. The only higher percentage of white clay pigment use is in the Mockingbird site vessel assemblage (see Table 8). There, 95 percent of the engraved vessels with pigments have a white clay pigment, including all of the carinated bowls $(n=12)$, compound bowls $(n=5)$, one bottle, and one bowl; another bowl had a red clay pigment (Perttula et al. 1998). Forty-three percent of the engraved vessels in the assemblage have a pigment applied to the decorative elements.

Other Late Caddo period Titus phase vessel assemblages in the Little and Big Cypress Creek basins in East Texas are dominated by vessels with white clay pigment, especially on carinated bowls and compound bowls as well as jars; bottles mainly have red clay pigments (Perttula et al. 2012a, 2012b, 2012c); this pigment use is quite comparable to the vessel assemblage at the H. R. Taylor site. Bowls in these assemblages, which rarely have pigments, have both red and white pigments; ollas tended not to have an applied pigment of either color (Perttula et al. 2012a:35). 
In the upper Neches River basin, by contrast, a temporal series of Late Caddo Frankston phase fine ware vessels are dominated by vessels with a red clay pigment, at least from ca. A.D. 1400-1560 (see Table 8). In those assemblages, 92.5 percent of the fine ware vessels with pigment have a red clay pigment, and this includes bottles, bowls, and effigy bowls. After ca. A.D. 1560, only 36 percent of the vessels with pigment have a red clay pigment, and instead use of a white clay pigment predominates; most of these vessels are carinated bowls (Perttula 2011:279-280).

In the Historic Caddo vessel assemblages from the nearby Goode Hunt and Clements site, both ca. A.D. 1680-1730 Nasoni Caddo cemeteries (Perttula 2015), pigment use on engraved fine ware vessels ranges from 25-29 percent of the sample of engraved vessels. Eighty percent of these vessels have a red clay pigment, and this includes bottles ( $n=4,100$ percent), bowls and compound bowls $(n=2,100$ percent), and carinated bowls $(n=9,67$ percent). Only a few carinated bowls in the vessel assemblages at both sites have a white clay pigment.

Ancestral Caddo potters in sites and communities in what is now East Texas used clay pigments, either red or white in color, to embellish fine ware engraved ceramic vessels. This was a practice that was established and used for at least nine centuries. The relatively common occurrence of pigments on fine ware vessels suggests that both red and white clay pigments were readily accessible to Caddo potters in communities across East Texas, and it is likely that there was an active trade/exchange of pigments across the region that were secured from sources of hematite and kaolin clay.

There were spatial and temporal differences in the frequency of use of clay pigments by Caddo potters as well as in the pigments of choice to use on different vessel forms. The assemblages examined to date indicate that there was not one shared pattern or tradition in pigment use within sites occupied at different times or within different localities, although the use of red clay pigment appears to have been more common between ca. A.D. 1000-1400. Rather there was a diversity in pigment selection and use that is probably related to the meaning(s) of the two colors in different Caddo communities, and what the meanings were in different times and places.

Lankford (1992) discussed the importance of the use of either red or white colors in social, political, and cosmological contexts in Southeastern North American societies, and such contexts likely also apply to ancestral Caddo groups that lived in East Texas. As Hart and Perttula (2010:208) note, colors likely "symbolize the cosmological underpinnings of worldviews."

According to Bobby Gonzalez (April 2008 personal communication) "the red pigment means life and is very sacred among the Caddo. The red pigment is now used on peyote staffs, and during ritual ceremonies and prayer meetings, the red pigment is painted on and in the ears as well as on the top of the head in the middle of a man's hair line, running from front to back; the women and men paint themselves in the morning when the sun comes up." Caddo peoples bathed the deceased in red clay (Gonzalez 2005:57), and in historic times red was used as a paint or pigments on material items in ceremonies (Hart and Perttula 2010:208). Therefore, vessels with a red pigment likely are from vessels that symbolize life and its sacredness to the Caddo. It is possible that the red pigment seen on vessels placed in Caddo burials may have been added to the vessels shortly before they were placed in graves with the deceased.

"The white clay is also very sacred to the Caddo and was used for altars during Caddo peyote meetings" (Bobby Gonzalez, 2008 personal communication), and for doctoring cuts, burns, and stomach problems. In historic times, Caddo men painted their faces red and white, and white feathers were a sign of peace (Hart and Perttula 2010:208).

The alternating preference for red or white clay pigments by Caddo potters in different communities at different times may relate to social, political, or religious dualisms in Caddo lifeways. Thus, Lankford's (1992:76-77) suggestion that the two colors denote the Lower world of change (red) and 
the Upper world of order (white) has considerable significance in the interpretation of pigment use on ceramic vessels by Caddo peoples. Before ca. A.D. 1400, between ca. A.D. 1400-1560 in the upper Neches, and between ca. A.D. 1680-1730 among the Nasoni Caddo, red clay pigments appear to have been preferred by Caddo potters to embellish the decorations on fine ware vessels. Cosmological and world views of the Caddo began to change in certain communities in East Texas after ca. A.D. 1400, such that new cosmological and world views came to dominate beliefs and mortuary ritual use; one marker of this is different trends in pigment use. Fine ware engraved vessels in a number of mortuary vessel assemblages dating after ca. A.D. 1450 usually then had white pigments rubbed in the design, including the assemblage from the H. R. Taylor site. Finally, George Sabo has noted that color use by Caddo peoples "suggest an association of red and white with an ongoing cycle of life in which birth and death are subsumed" (May 2009 personal communication).

\section{Defined Ceramic Types}

There are 26 defined ceramic types, and a number of varieties of those types, both fine wares and utility wares, in the H. R. Taylor site vessel assemblage, with clear differences in the vessel forms that characterize each of the types (Table 9). Among the ceramic types that are considered to have been locally manufactured, the most common types comprise the set of Ripley Engraved (all varieties, 39.7 percent, but especially var. McKinney), Taylor Engraved (all varieties, 13.3 percent), Karnack BrushedIncised (10.3 percent), Wilder Engraved (all varieties, 5.6 percent), and Harleton Appliqued (5.4 percent).

Table 9. Defined ceramic types and vessel forms in the utility ware and fine ware vessels at the $\mathbf{H}$. R. Taylor site.

\begin{tabular}{|c|c|c|c|c|c|c|c|c|}
\hline Type & $\mathrm{CB}$ & CPB & $\mathrm{Bt}$ & $\mathrm{Bw}$ & $\mathrm{J}$ & $\mathrm{Ol}$ & DB & $\mathrm{N}$ \\
\hline \multicolumn{9}{|l|}{ Fine ware } \\
\hline Bailey Engraved & - & - & 6 & - & 1 & 1 & - & 8 \\
\hline Belcher Engraved & 3 & 5 & 1 & 1 & - & - & - & 10 \\
\hline Bowie Engraved & - & - & - & - & - & - & 1 & 1 \\
\hline Glassell Engraved & 4 & - & - & - & - & - & - & 4 \\
\hline Hodges Engraved & - & - & 2 & - & - & - & - & 2 \\
\hline Hood Engraved & - & - & - & 1 & - & - & - & 1 \\
\hline Keno Trailed & - & - & 3 & - & 1 & - & - & 4 \\
\hline Patton Engraved & - & - & - & - & 1 & - & - & 1 \\
\hline Poynor Engraved & 2 & - & - & - & - & - & - & 2 \\
\hline $\begin{array}{l}\text { Ripley Engraved, var. } \\
\text { Caldwell }\end{array}$ & 3 & 1 & - & 1 & - & - & - & 5 \\
\hline $\begin{array}{l}\text { Ripley Engraved, var. } \\
\text { Carpenter }\end{array}$ & 10 & - & - & - & - & - & - & 10 \\
\hline $\begin{array}{l}\text { Ripley Engraved, var. } \\
\text { Cash }\end{array}$ & 6 & - & - & - & - & - & - & 6 \\
\hline $\begin{array}{l}\text { Ripley Engraved, var. } \\
\text { Galt }\end{array}$ & 14 & - & - & - & 1 & - & - & 15 \\
\hline $\begin{array}{l}\text { Ripley Engraved, var. } \\
\text { Gandy }\end{array}$ & 6 & - & - & - & - & - & - & 6 \\
\hline $\begin{array}{l}\text { Ripley Engraved, var. } \\
\text { McKinney }\end{array}$ & 71 & 1 & - & 1 & - & - & - & 73 \\
\hline $\begin{array}{l}\text { Ripley Engraved, var. } \\
\text { McKinney-Enis Smith }\end{array}$ & 6 & - & - & - & - & - & - & 6 \\
\hline $\begin{array}{l}\text { Ripley Engraved, var. } \\
\text { Pilgrims }\end{array}$ & 11 & 1 & - & - & - & - & - & 12 \\
\hline $\begin{array}{l}\text { Ripley Engraved, var. } \\
\text { Ripley }\end{array}$ & - & - & 5 & - & 1 & - & - & 6 \\
\hline
\end{tabular}


Table 9. Defined ceramic types and vessel forms in the utility ware and fine ware vessels at the $H$. R. Taylor site, cont.

\begin{tabular}{|c|c|c|c|c|c|c|c|c|}
\hline Type & $\mathrm{CB}$ & $\mathrm{CPB}$ & $\mathrm{Bt}$ & $\mathrm{Bw}$ & $\mathrm{J}$ & $\mathrm{Ol}$ & DB & $\mathrm{N}$ \\
\hline $\begin{array}{l}\text { Ripley Engraved, var. } \\
\text { Williams }\end{array}$ & 11 & 1 & - & 1 & - & - & - & 13 \\
\hline $\begin{array}{l}\text { Ripley Engraved, var. } \\
\text { unspecified }\end{array}$ & 11 & - & 4 & 2 & 1 & - & - & 18 \\
\hline Simms Engraved & 5 & - & - & - & 1 & - & - & 6 \\
\hline $\begin{array}{l}\text { Taylor Engraved, } \\
\text { var. Taylor }\end{array}$ & 22 & - & - & 4 & - & - & - & 26 \\
\hline $\begin{array}{l}\text { Taylor Engraved, var. } \\
\text { Copeland }\end{array}$ & - & - & 22 & - & - & - & - & 22 \\
\hline $\begin{array}{l}\text { Taylor Engraved, var. } \\
\text { unspecified }\end{array}$ & 5 & - & 2 & - & 1 & 1 & - & 9 \\
\hline Turner Engraved & - & 4 & - & - & - & - & - & 4 \\
\hline $\begin{array}{l}\text { Wilder Engraved, var. } \\
\text { Wilder }\end{array}$ & - & - & 8 & - & - & 2 & - & 10 \\
\hline $\begin{array}{l}\text { Wilder Engraved, var. } \\
\text { unspecified }\end{array}$ & 1 & - & 10 & 2 & - & 1 & - & 14 \\
\hline \multicolumn{9}{|l|}{ Utility ware } \\
\hline Belcher Ridged & - & - & - & - & 1 & - & - & 1 \\
\hline Bullard Brushed & - & - & - & - & 15 & - & - & 15 \\
\hline Cass Appliqued & - & - & - & - & 9 & - & - & 9 \\
\hline Foster Trailed-Incised & - & - & - & - & 2 & - & - & 2 \\
\hline Harleton Appliqued & - & - & - & - & 23 & - & - & 23 \\
\hline Karnack Brushed-Incised & - & - & - & - & 44 & - & - & 44 \\
\hline Killough Pinched & - & - & - & - & 1 & - & - & 1 \\
\hline La Rue Neck Banded & - & - & - & - & 14 & - & - & 14 \\
\hline Maydelle Incised & - & - & - & - & 11 & - & - & 11 \\
\hline cf. Mockingbird Punctated & - & - & - & - & 4 & - & - & 4 \\
\hline Moore Noded & - & - & - & 3 & - & - & - & 3 \\
\hline Pease Brushed-Incised & - & - & - & - & 7 & - & - & 7 \\
\hline Totals & 191 & 13 & 63 & 16 & 139 & 5 & 1 & $428^{*}$ \\
\hline
\end{tabular}

$\mathrm{CB}=$ carinated bowl; $\mathrm{CPB}=$ compound bowl; $\mathrm{Bt}=$ bottle; $\mathrm{Bw}=$ bowl; $\mathrm{J}=\mathrm{jar} ; \mathrm{Ol}=\mathrm{olla} ; \mathrm{DB}=\mathrm{deep}$ bowl

*does not include the 16 fine ware vessels that have multiple and distinctive motifs from different defined types (see below)

The most common types identified in the carinated bowls are Ripley Engraved, var. McKinney (37.2 percent), Taylor Engraved, var. Taylor (with hooked arm scrolls, 11.5 percent), and Ripley Engraved, var. Galt (7.3 percent) (see Table 9). In the bottles, the best represented types include Taylor Engraved, var. Copeland (with concentric engraved spirals and hooked arm elements, 34.9 percent), and Wilder Engraved (both varieties, 28.6 percent). Compound bowls are dominated by Belcher Engraved (38.5 percent) and Turner Engraved (all varieties, 30.8 percent) vessels. Among the fine wares, Taylor Engraved, var. Taylor bowls comprise 25 percent of the identified sample, while Moore Noded bowls represent 18.8 percent of the bowl assemblage. Ollas are primarily Wilder Engraved vessels, and the one deep bowl is of the Bowie Engraved type, probably a traded/exchanged vessel from McCurtain phase Caddo peoples (see Suhm and Jelks 1962:17). 
With the exception of the three Moore Noded bowls in the ceramic vessel assemblage, the remainder of the utility ware vessels from burial features at the H. R. Taylor site are jars (see Table 9). The most common utility ware jars are Karnack Brushed-Incised (31.7 percent of all the jars), Harleton Appliqued (16.6 percent), and La Rue Neck Banded (10.1 percent).

\section{Non-Local Vessels in the Assemblage}

About 9.1 percent of the vessels in the H. R. Taylor assemblage appear to have been made outside the Big Cypress Creek basin among other Caddo groups (Table 10) living either in the upper Neches River basin or among Kadohadacho groups from the mid-Red River in East Texas/Southeast Oklahoma downstream to Northwest Louisiana (Figure 8); the former are McCurtain phase people, and the latter are Belcher and Chakanina phase Caddo peoples (Figure 9). More than 82 percent of these vessels likely were manufactured among the Belcher and Chakanina phase Caddo peoples, based on ceramic decorative styles and the use of shell temper, compared to only 12.8 percent of the vessels originating in the upper Neches River basin among Frankston and Allen phase Caddo peoples, and 5.1 percent from McCurtain phase Caddos probably living in the Mound Prairie area of Red River County along the Red River in East Texas.

Table 10. Ceramic vessels identified as non-local ceramic types at the $H$. $R$. Taylor cemetery.

\begin{tabular}{|c|c|c|c|}
\hline \multirow[t]{2}{*}{ Type } & \multirow[b]{2}{*}{ mid-Red River } & \multicolumn{2}{|l|}{ Non-Local } \\
\hline & & $\begin{array}{l}\text { Kadohadacho- } \\
\text { Red River }\end{array}$ & $\begin{array}{l}\text { upper Neches } \\
\text { River basin }\end{array}$ \\
\hline Belcher Engraved & - & 10 & - \\
\hline Belcher Ridged & - & 1 & - \\
\hline Bowie Engraved & 1 & - & - \\
\hline $\begin{array}{l}\text { Foster Trailed- } \\
\text { Incised }\end{array}$ & - & 2 & - \\
\hline Glassell Engraved & - & 4 & - \\
\hline Hodges Engraved & - & 2 & - \\
\hline Hood Engraved & - & - & 1 \\
\hline $\begin{array}{l}\text { Karnack Brushed- } \\
\text { Incised }\end{array}$ & - & 1 & - \\
\hline Killough Pinched & - & - & 1 \\
\hline Keno Trailed & - & 4 & - \\
\hline Moore Noded & - & 3 & - \\
\hline Patton Engraved & - & - & 1 \\
\hline Poynor Engraved & - & - & 2 \\
\hline Simms Engraved & 1 & 5 & - \\
\hline Totals & 2 & 32 & 5 \\
\hline
\end{tabular}




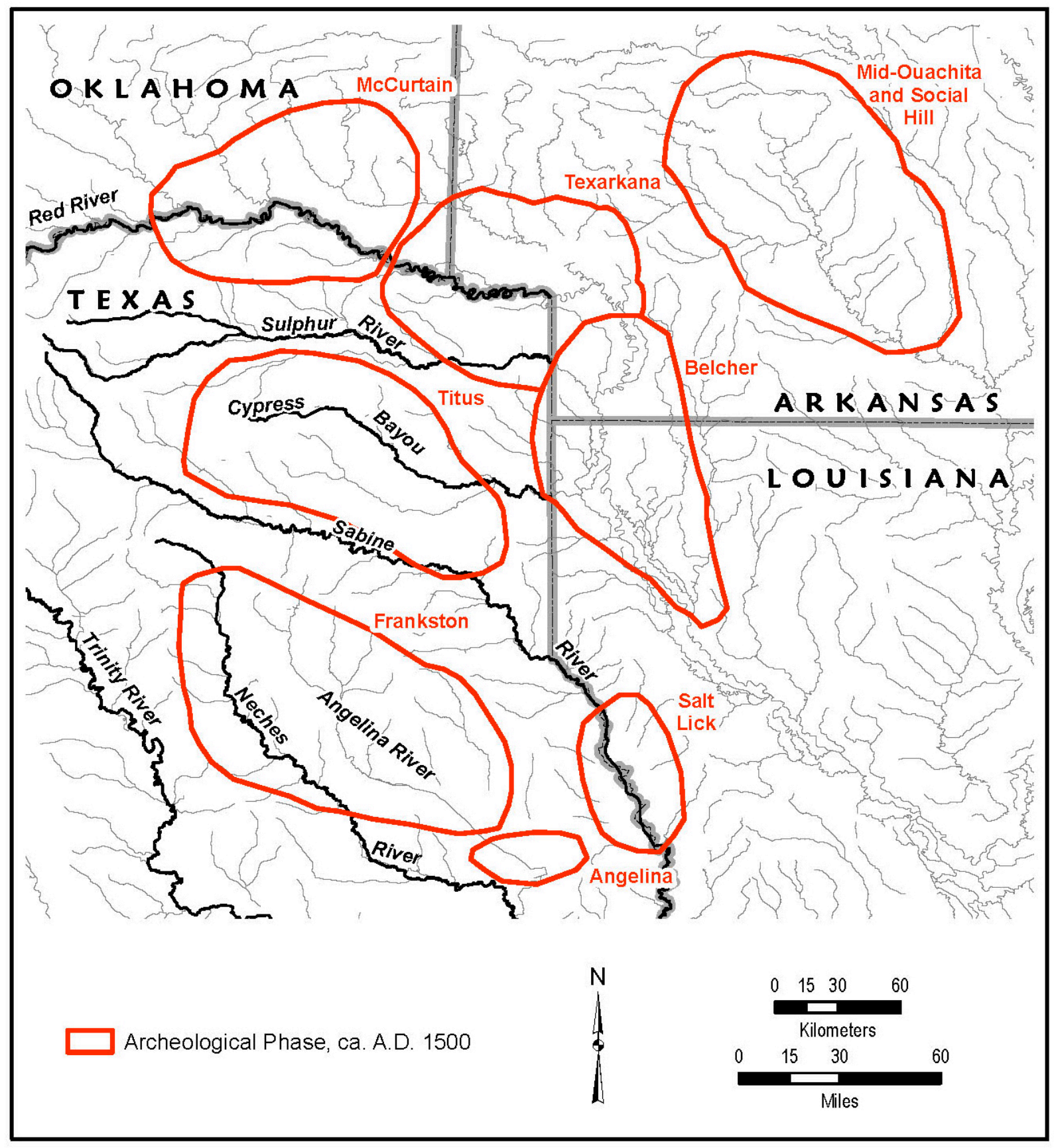

Figure 8. Distribution of defined phases in the southern Caddo area at ca. A.D. 1500. Figure prepared by Sandra Hannum. 


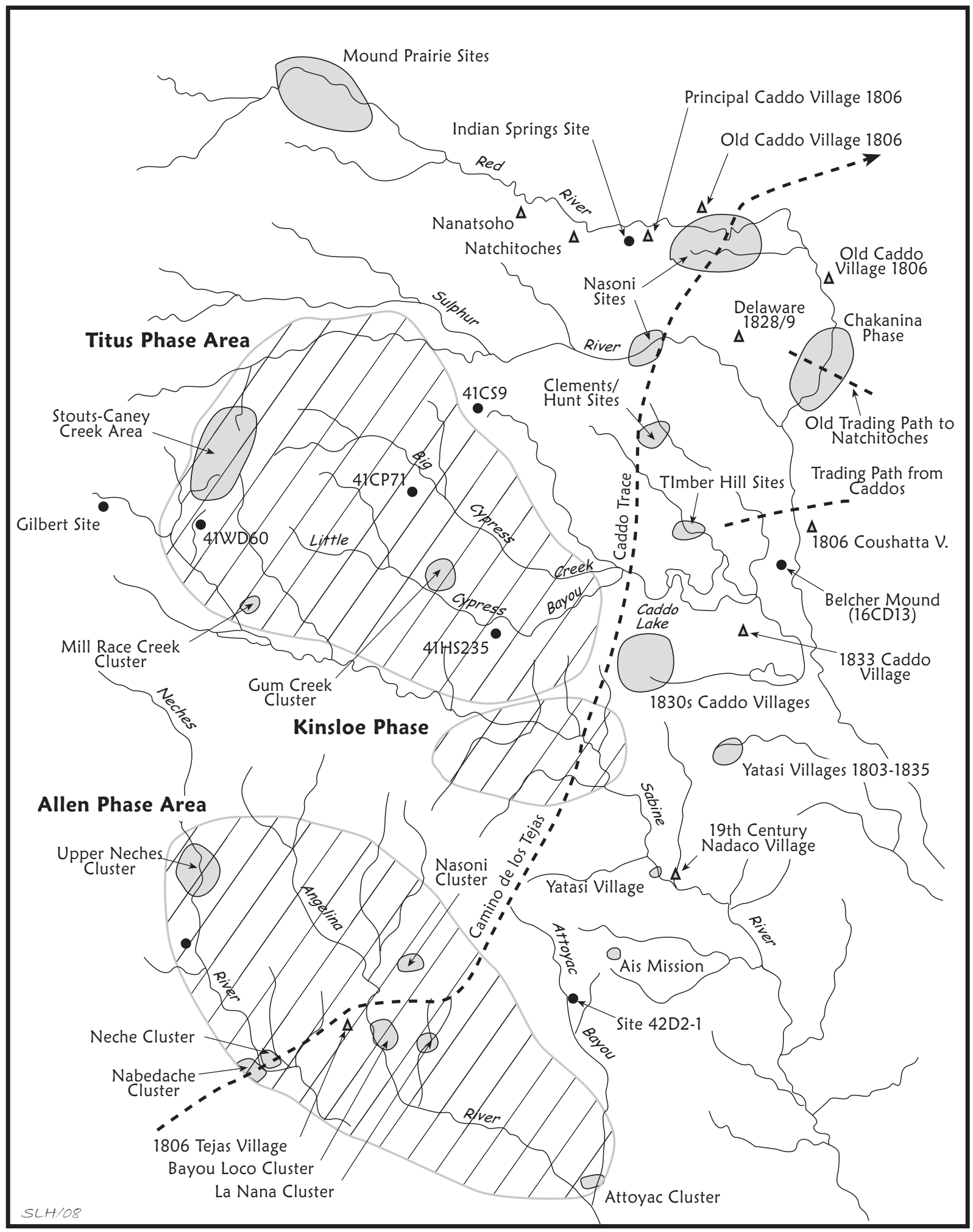

Figure 9. Historic Caddo sites and phases, and locations of recorded Caddo villages in East Texas and adjoining parts of Southwest Arkansas and Northwest Louisiana. 


\section{Vessels with Multiple Motifs}

There are 16 vessels in the assemblage that have two different motifs on them-either on the upper panel vs. the lower panel or on the rim vs. body-where the motifs are characteristic or two different defined ceramic types or different varieties of the same type (Table 11). The most common combinations are Simms Engraved-Taylor Engraved bowls and carinated bowls (25 percent of these vessels), with a Simms Engraved motif on the vessel rim and a Taylor Engraved motif on the vessel body, followed by Belcher Engraved-Ripley Engraved compound bowls ( $n=3$ ), and Ripley Engraved-Belcher Engraved bowls and compound bowls. In only one case is there a vessel (a carinated bowl) that has motifs from two different varieties of the same defined ceramic type: Ripley Engraved, var. Caldwell (on the rim) and var. Gandy on the vessel body.

Table 11. Vessels with two different motifs in the H. R. Taylor site vessel assemblage.

\begin{tabular}{|c|c|}
\hline Motifs/Types & Vessel Form \\
\hline Bailey Engraved (body)-Hodges Engraved (body) & Bottle \\
\hline $\begin{array}{l}\text { Belcher Engraved (upper panel)-Ripley Engraved } \\
\text { (lower panel) }\end{array}$ & Compound bowl \\
\hline $\begin{array}{l}\text { Belcher Engraved (upper panel)-Ripley Engraved, var. } \\
\text { McKinney (lower panel) }\end{array}$ & Compound bowl \\
\hline $\begin{array}{l}\text { Belcher Engraved (upper panel)-Ripley Engraved, var. } \\
\text { Pilgrims (lower panel) }\end{array}$ & Compound bowl \\
\hline Belcher Engraved (rim)-Wilder Engraved (body) & Jar \\
\hline Ripley Engraved (rim)-Belcher Engraved (body) & Bowl \\
\hline $\begin{array}{l}\text { Ripley Engraved, var. Gandy (upper panel)-Belcher } \\
\text { Engraved (lower panel) }\end{array}$ & Compound bowl \\
\hline Ripley Engraved (rim)-Hodges Engraved (body) & Carinated bowl \\
\hline Ripley Engraved (rim)-Taylor Engraved (body) & Carinated bowl \\
\hline $\begin{array}{l}\text { Ripley Engraved, var. Caldwell (rim)-Ripley Engraved, } \\
\text { var. Gandy (body) }\end{array}$ & Carinated bowl \\
\hline Simms Engraved (rim)-Taylor Engraved (body) & Bowl $(n=2)$ \\
\hline Simms Engraved (rim)-Taylor Engraved (body) & Carinated bowl $(\mathrm{n}=2)$ \\
\hline Simms Engraved (rim)-Wilder Engraved (body) & Carinated bowl \\
\hline Turner Engraved (upper panel)-Wilder Engraved & Compound bowl \\
\hline
\end{tabular}

Since the vessels have stylistic motifs from distinctly different ceramic types that are thought to have been made in several different locales in the Caddo area-i.e., Belcher Engraved, Hodges Engraved, and Taylor Engraved in the Belcher phase; Ripley Engraved, Taylor Engraved, Turner Engraved, and Wilder Engraved in the Titus phase; and Simms Engraved in the McCurtain phase-the place of manufacture and decoration of these vessels is open to question. Which Caddo potters from which communities or phases decorated these vessels? Regardless, these distinctive vessels with shared motifs are evidence of the existence of close social networks and the transmission of stylistic attributes between different Caddo communities in East Texas and along the Red River after ca. A.D. 1600. 


\section{Estimated Age of the Cemetery}

There are no radiocarbon dates, unfortunately, from any of the burial features at the H. R. Taylor site; preserved organic remains on a number of the vessels would be suitable for radiocarbon dating if funds could be found to process such radiocarbon samples. Determining the estimated age of the cemetery and its burial features at the H. R. Taylor site relies instead on: (1) the stylistic character of the decorated vessels that had been placed in the burials as well as the distinctive form of some of the vessels, such as the spool neck attribute on certain bottles, and (2) the stylistic character of the arrow points placed in the burials.

One way to likely establish the temporal age of the cemeteries is through the consideration of the seriation of Ripley Engraved rim motifs, as discussed in Perttula (1992:243-249). This frequency seriation was developed through a co-association of arrow point caches of different types (Perdiz, Bassett, Maud, and Talco) with distinctive Ripley Engraved rim motifs at a number of cemeteries (see Thurmond 1990; Turner 1978), namely the continuous scroll (var. Carpenter), the scroll (var. Gandy), scroll and circle (var. Galt), and the pendant triangle (var. McKinney). Presuming that the Perdiz arrow point was the earliest type used by Titus phase peoples, followed by the Bassett, Maud, and Talco points in later burials, the seriation suggests that the earliest style of Ripley Engraved was the var. Carpenter motif, then next came var. Gandy vessels, followed by var. Galt, and then by var. McKinney vessels (Table 12, see also Perttula 1992:Table A-2).

Table 12. Temporal seriation of fine ware types (Ripley Engraved and Womack Engraved) and Ripley Engraved varieties and suggested temporal subdivisions of the Titus phase.

\begin{tabular}{|c|c|c|c|c|c|c|c|}
\hline $\begin{array}{l}\text { Divisions in Titus } \\
\text { phase }\end{array}$ & $\begin{array}{l}\text { Motifs/ } \\
\text { Type }\end{array}$ & $\begin{array}{l}\text { Simms } \\
\text { Eng. }\end{array}$ & $\begin{array}{l}\text { Taylor } \\
\text { Eng. }\end{array}$ & $\begin{array}{l}\text { var. } \\
\text { Caldwell }\end{array}$ & $\begin{array}{l}\text { var. } \\
\text { Williams }\end{array}$ & $\begin{array}{l}\text { var. } \\
\text { Cash }\end{array}$ & $\begin{array}{l}\text { Turner } \\
\text { Eng. }\end{array}$ \\
\hline $\begin{array}{l}\text { Early Titus phase } \\
\text { (ca. A.D. 1430-1550) }\end{array}$ & $\begin{array}{l}\text { var. Carpenter } \\
\text { var. Gandy }\end{array}$ & & $\mathrm{x}$ & & & $\mathrm{x}$ & \\
\hline $\begin{array}{l}\text { Late Titus phase } \\
\text { (ca. A.D. 1550-1680) }\end{array}$ & $\begin{array}{l}\text { cf. var. Gandy } \\
\text { var. Galt } \\
\text { var. McKinney }\end{array}$ & $\mathrm{x}$ & $x$ & $\mathrm{x}$ & $\begin{array}{l}x \\
x\end{array}$ & & $\mathrm{x}$ \\
\hline post-A.D. 1680 & $\begin{array}{l}\text { Womack } \\
\text { Engraved }\end{array}$ & $\mathrm{x}$ & & & & & \\
\hline
\end{tabular}

$\mathrm{x}=$ present

It is suspected that inverted rim carinated bowls are a post-A.D. 1600 ceramic innovation among Titus phase potters and other Caddo groups, becoming relatively frequent in a number of late $17^{\text {th }}$ century Caddo sites in the Sabine, Sulphur, and Big Cypress drainage basins, and such vessels were made into the midlate $18^{\text {th }}$ century as well (Perttula 2007:141-142). Thus, the latest cemetery use may be burials at the H. R. Taylor site that include Ripley Engraved, var. McKinney, as well as inverted rim vessels, as such vessels may well have been made by Titus phase Caddo peoples shortly before and after ca. A.D. 1680.

The analysis of the age of burial features at the Tuck Carpenter site (41CP5), particularly the coassociation of arrow points and defined varieties of Ripley Engraved in burial features, suggests that Ripley Engraved, var. McKinney and Talco arrow points occur in burial features that date after ca. A.D. 1600. They also have Ripley Plain carinated bowls and La Rue Neck Banded and Mockingbird Punctated jars; 66.7 percent of the Ripley Engraved vessels associated with Talco arrow points are Ripley 
Engraved, var. McKinney (see Perttula et al. 2017:Table 9). Also present exclusively in this group of burials are Simms Engraved and Turner Engraved, var. Turner vessels, including the stemmed vessel or chalice in Burial 33 (see Turner 1978:Figure 34c). Wilder Engraved, var. Wilder bottles are also relatively common in the burial features with Talco arrow points (see Perttula et al. 2017:Tables 8 and 9). Thus, the burial features with Talco arrow points at Tuck Carpenter, and also at H. R. Taylor, likely date after ca. A.D. 1600, and may date as late as ca. A.D. 1680.

In general, the H. R. Taylor cemetery appears to have been used primarily after ca. A.D. 1600, and for a maximum of two or three generations, until approximately A.D. 1680 or shortly thereafter - which is supported by the Talco arrow points in numerous burials - and the burials across the cemetery have relatively high proportions of var. McKinney vessels. The occurrence of several Keno Trailed vessels (jars and bottles) and one Patton Engraved vessel are the best evidence for the last use of the H. R. Taylor cemetery having taken place shortly after ca. A.D. 1680. The absence of European trade goods in any of the burials indicate the cemetery was abandoned before ca. A.D. 1720.

\section{Spatial Structure of the Cemetery and Distribution of Funerary Offerings across the Cemetery}

The character of the treatment and position of burial features, and the kinds of funerary offerings placed with the deceased in burial features at the H. R. Taylor site (see Perttula 2018:Figures 9-18), have been employed to define a cemetery core with 39 individual burial features, and five outer sections to the north, northeast, south, southwest, and west/ northwest of the core (Figure 10); there are 25 individual burials in these outer sections. These outer sections, with six, four, four, four, and seven burial features, respectively, may represent the later spatial and temporal extension of the placement of burial features outside of the cemetery core, based on the relative frequency of certain specific ceramic types and varieties as well as Talco arrow points.

As will be discussed in more detail, the spatial diversity in the kinds of distinctive burial treatments and in the placement of funerary offerings is considerable among the ancestral Caddo burial features in the core and outer sections of the cemetery. Attributes of the funerary offerings and mortuary practices that are shared between all sections of the cemetery include only:

- burials with more than nine vessels;

- extra-large utility ware jars;

- vessels with a rounded base;

- vessels (carinated bowls) with an inverted rim;

- Ripley Engraved carinated bowls;

- Ripley Engraved, var. Galt vessels;

- Ripley Engraved, var. McKinney vessels;

- Ripley Engraved, var. Pilgrims vessels;

- Taylor Engraved, var. Taylor carinated bowls;

- Taylor Engraved, var. Copeland bottles;

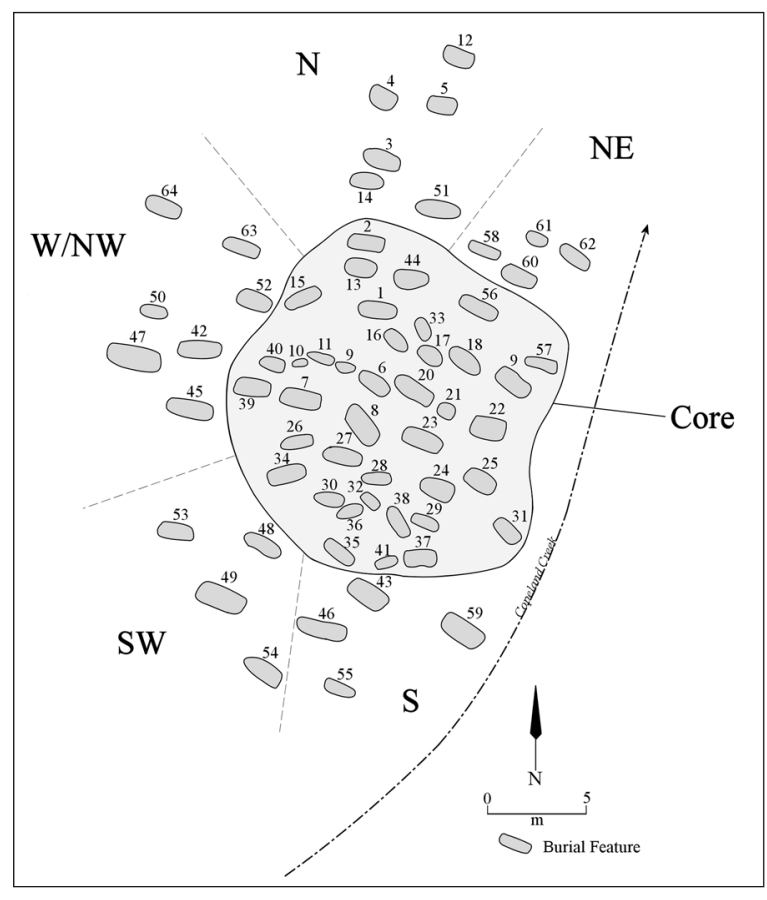

Figure 10. Burial features in the core of the cemetery at the H. R. Taylor site, as well as burial features to the north, northeast, south, southwest, and west/northwest outer sections. 
- Wilder Engraved bottles;

- the use of a white clay pigment on engraved vessels;

- and Talco arrow points.

Ripley Engraved, var. McKinney vessels and Talco arrow points are the most common funerary offerings shared between the burials in the different cemetery sections.

Table 13 summarizes the relative proportions of different burial treatment attributes and funerary offerings in the core area as well as the outer sections of the cemetery. The attributes and funerary offerings are arranged by their predominance in the different cemetery areas.

Table 13. Predominance of different burial treatment attributes and funerary offerings by cemetery core area and outer sections.

\begin{tabular}{|c|c|c|c|c|c|c|c|}
\hline $\begin{array}{l}\text { Attribute/ } \\
\text { offering }\end{array}$ & Core & $\mathrm{N}$ & $\mathrm{NE}$ & $\mathrm{S}$ & SW & W/NW & $\begin{array}{l}\text { All } \\
\text { areas }\end{array}$ \\
\hline Conjoined vessel & + & & & & & & \\
\hline Moore Noded & + & & & & & & \\
\hline $\begin{array}{l}\text { Ripley Engraved, var. } \\
\text { Cash }\end{array}$ & + & & & & & & \\
\hline Glassell Engraved & + & & & & & & \\
\hline Foster Trailed-Incised & + & & & & & & \\
\hline Maud points & + & + & & & & & \\
\hline $\begin{array}{l}\text { Ripley Engraved, var. } \\
\text { Pilgrims }\end{array}$ & + & & + & + & + & & + \\
\hline Wilder Engraved & + & & + & + & + & & + \\
\hline Bassett points & + & & & + & & & \\
\hline Elite burials & + & & & + & + & + & \\
\hline $\begin{array}{l}\text { Highest density of } \\
\text { offerings }\end{array}$ & + & & & + & + & + & \\
\hline Cass Appliqued & + & & & & + & & \\
\hline Ripley Engraved Bottle & + & & & & + & & \\
\hline $\begin{array}{l}\text { Points by right side } \\
\text { of body }\end{array}$ & + & & & & + & + & \\
\hline Plain ware & + & & & & & + & \\
\hline Bullard Brushed & + & & & & & + & \\
\hline White sand in feature & & + & & & & & \\
\hline Pease Brushed-Incised & & + & + & & & & \\
\hline Turner Engraved & & + & & & & + & \\
\hline Taylor Engraved Bottle & & + & & & & + & + \\
\hline $\begin{array}{l}\text { Ripley Engraved, var. } \\
\text { Gandy }\end{array}$ & & & + & & & & \\
\hline $\begin{array}{l}\text { Ripley Engraved, var. } \\
\text { McKinney-Enis Smith }\end{array}$ & & & + & & & & \\
\hline $\begin{array}{l}\text { Ripley Engraved, var. } \\
\text { Williams }\end{array}$ & & & + & & & & \\
\hline Shell-tempered vessels & & & + & & & & \\
\hline Bowie Engraved & & & + & & & & \\
\hline
\end{tabular}


Table 13. Predominance of different burial treatment attributes and funerary offerings by cemetery core area and outer sections, cont.

\begin{tabular}{|c|c|c|c|c|c|c|c|}
\hline $\begin{array}{l}\text { Attribute/ } \\
\text { offering }\end{array}$ & Core & $\mathrm{N}$ & $\mathrm{NE}$ & S & SW & W/NW & $\begin{array}{l}\text { All } \\
\text { areas }\end{array}$ \\
\hline red pigment & & & + & & & & \\
\hline Engraved/Trailed Jar & & & + & & & & \\
\hline $\begin{array}{l}\text { Points by left side } \\
\text { of body }\end{array}$ & & & + & & & & \\
\hline Ripley Engraved CB & & & + & + & + & + & + \\
\hline Paint stones & & & + & & + & & \\
\hline Clay masses & & & $+*$ & & + & & \\
\hline Bailey Engraved & & & + & & & + & \\
\hline$>10$ arrow points & & & & + & & & \\
\hline Karnack Brushed-Incised & & & & + & & & \\
\hline Maydelle Incised & & & & + & & & \\
\hline Points by mid-body & & & & + & & & \\
\hline $\begin{array}{l}\text { Ripley Engraved, var. } \\
\text { Carpenter }\end{array}$ & & & & + & + & + & \\
\hline white pigment & & & & + & + & + & + \\
\hline Keno Trailed & & & & + & & + & \\
\hline$>9$ vessels & & & & + & & + & + \\
\hline Taylor Engraved CB & & & & + & & & + \\
\hline Talco points & & & & + & & & + \\
\hline Celts & & & & & + & & \\
\hline Galt biface & & & & & + & & \\
\hline Ceramic Ear Spools & & & & & + & & \\
\hline Belcher Engraved & & & & & + & & \\
\hline $\begin{array}{l}\text { Extra-large compound } \\
\text { bowls }\end{array}$ & & & & & + & & \\
\hline $\begin{array}{l}\text { Ripley Engraved, var. } \\
\text { Caldwell }\end{array}$ & & & & & + & & \\
\hline Taylor Engraved Bw & & & & & + & & \\
\hline Hodges Engraved & & & & & + & + & \\
\hline $\begin{array}{l}\text { Vessels with rounded } \\
\text { base }\end{array}$ & & & & & + & & + \\
\hline Evidence of fire & & & & & & + & \\
\hline Quartz crystal & & & & & & + & \\
\hline Ceramic Pipes & & & & & & + & \\
\hline $\begin{array}{l}\text { Extra-large carinated } \\
\text { bowls }\end{array}$ & & & & & & + & \\
\hline Ollas & & & & & & + & \\
\hline Effigy bowls & & & & & & + & \\
\hline Miniature vessels & & & & & & + & \\
\hline Bone-tempered vessels & & & & & & + & \\
\hline Belcher Ridged & & & & & & + & \\
\hline
\end{tabular}


Table 13. Predominance of different burial treatment attributes and funerary offerings by cemetery core area and outer sections, cont.

\begin{tabular}{|c|c|c|c|c|c|c|c|}
\hline $\begin{array}{l}\text { Attribute/ } \\
\text { offering }\end{array}$ & Core & $\mathrm{N}$ & $\mathrm{NE}$ & $\mathrm{S}$ & SW & W/NW & $\begin{array}{l}\text { All } \\
\text { areas }\end{array}$ \\
\hline Harleton Appliqued & & & & & & + & \\
\hline La Rue Neck Banded & & & & & & + & \\
\hline UID Utility Ware & & & & & & + & \\
\hline $\begin{array}{l}\text { Ripley Engraved, var. } \\
\text { unspecified }\end{array}$ & & & & & & + & \\
\hline Simms Engraved & & & & & & + & \\
\hline Patton Engraved & & & & & & + & \\
\hline Taylor Engraved Olla & & & & & & + & \\
\hline Taylor Engraved Jar & & & & & & + & \\
\hline Red-Slipped Vessel & & & & & & + & \\
\hline $\begin{array}{l}\text { Vessels with multiple } \\
\text { engraved motifs }\end{array}$ & & & & & & + & \\
\hline UID Fine ware & & & & & & + & \\
\hline Inverted rim vessels & & & & & & + & + \\
\hline Extra-large jars & & & & & & + & + \\
\hline $\begin{array}{l}\text { Ripley Engraved, var. } \\
\text { Galt }\end{array}$ & & & & & & + & + \\
\hline $\begin{array}{l}\text { Ripley Engraved, var. } \\
\text { McKinney }\end{array}$ & & & & & & + & + \\
\hline
\end{tabular}

Certainly the most distinctive of the burial features at the H. R. Taylor site in terms of funerary offerings is Burial A-45, in the northern core of the cemetery. Placed in the burial at the time of interment were 26 ceramic vessels, three ceramic pipes (representing 75 percent of the pipes placed in all the known burials in the cemetery), 23 Talco arrow points, two celts (22 percent of the celts placed in burials in the cemetery), nine paint stones (47 percent of the paint stones placed in burials in the cemetery), five polished pebbles (45 percent of the polished pebbles placed in burials in the cemetery), three small sandstone slab fragments or whetstones (100 percent of the whetstones placed in burials in the cemetery) (see Pearce and Jackson 1931:155), as well as one quartzite flake tool, two manos, and one hammerstone. Thurmond (1990:167) suggested - in the absence of preserved human remains - that Burial A-45 is that of two individuals buried together, primarily because of the large size of the burial pit $(236 \times 104 \mathrm{~cm})$, the diversity of funerary offerings, and comparisons to two known double burials at the Tuck Carpenter site (41CP5) cemetery (Turner 1978:32-35 and Figure 8).

Originally I had concurred with the identification of Burial A-45 at the H. R. Taylor site as being that of a double burial (Perttula 1992:Figure 19), with extended supine burials of probable male and female adults (Perttula 2012:Table 13-5). However, upon further review of the findings presented in Pearce and Jackson (1931:100-106), I am now inclined to interpret Burial A-45 as that of one individual-an adult male - with a high density of funerary offerings (Figure 11a) placed around the head, at the feet, and on both left and right sides of the body. Other elite burials occur in the core area of the cemetery, as well as the south, southwest, and west/northwest areas (Figure 11b), suggesting that elite members of the ancestral Caddo society that buried their dead at the H. R. Taylor site, continued to live in the community throughout the entirety of its cemetery use. 


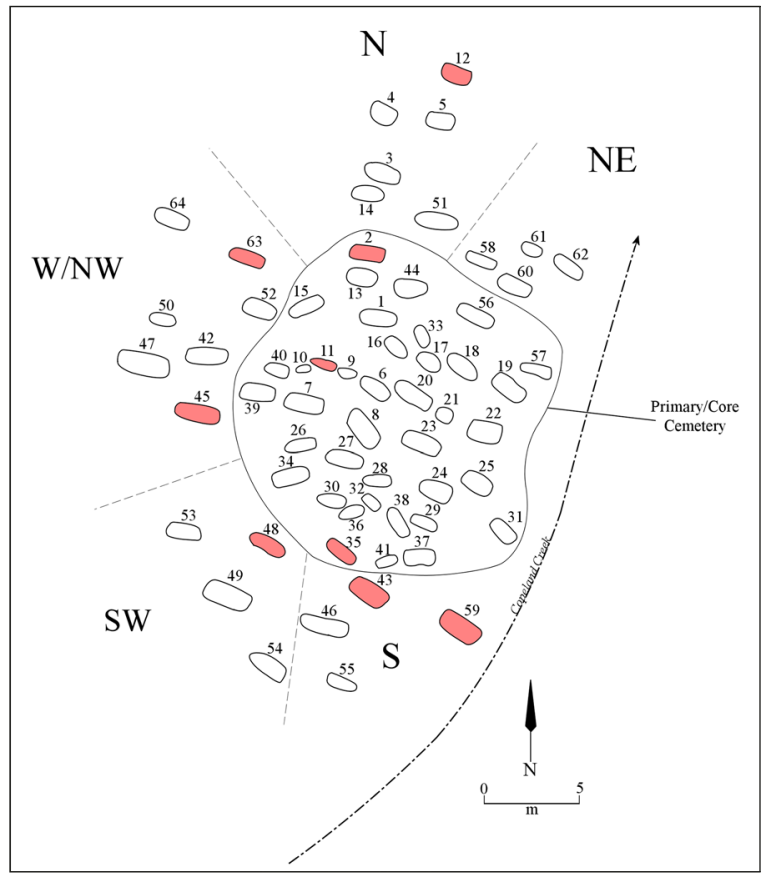

Figure 11a. Burials with the highest number of funerary offerings at the H. R. Taylor cemetery.

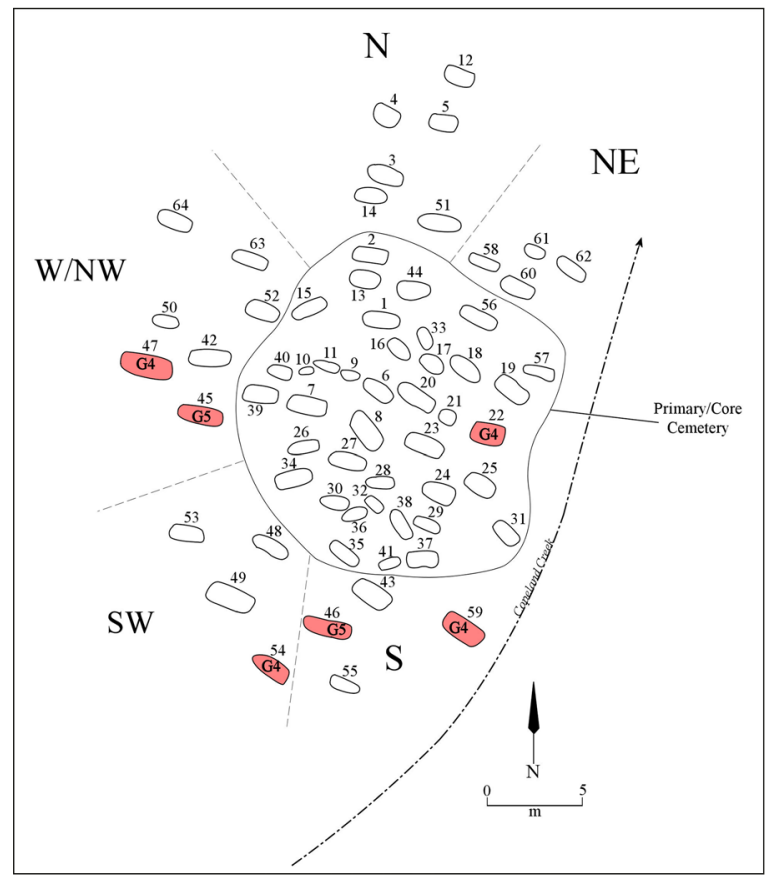

Figure 11b. Possible elite burials (Groups 4 and 5 in Fields et al. [2014) at the H. R. Taylor cemetery.

Fields et al. (2014:425 and Table 7.13) interpret Burial A-45 to be that of a very high-status burial feature within the local community and within the Titus phase, because of its grave size, number of ceramic vessels, variety of funerary offerings, some of which are of exotic origin. This burial is one of six high status burial features in the cemetery (see Figure 11b), their being placed in the core area, as well as the south, southwest, and west/northwest sections. Burial features with the highest densities of artifacts - although not all high-status burials are present in four of the outer sections of the cemetery, with the highest proportions in the south section (see Figure 11a).

Although a wide range of funerary offerings and burial treatments are present in the core of the cemetery, the funerary offerings that are predominant in the core area of the cemetery include conjoined vessels (i.e., vessels comprised of two different vessel forms welded together during the vessel manufacture process) (Figure 12), Moore Noded bowls (Figure 13), Ripley Engraved, var. Cash vessels (Figure 14), Glassell Engraved vessels (Figure 15), and a Foster Trailed-Incised vessel (Figure 16).

Maud arrow points are predominant in burials in the core area as well as the northern outer section (Figure 17), while Bassett arrow points were funerary offerings in the core and southern sections of the cemetery. Ripley Engraved, var. Pilgrims

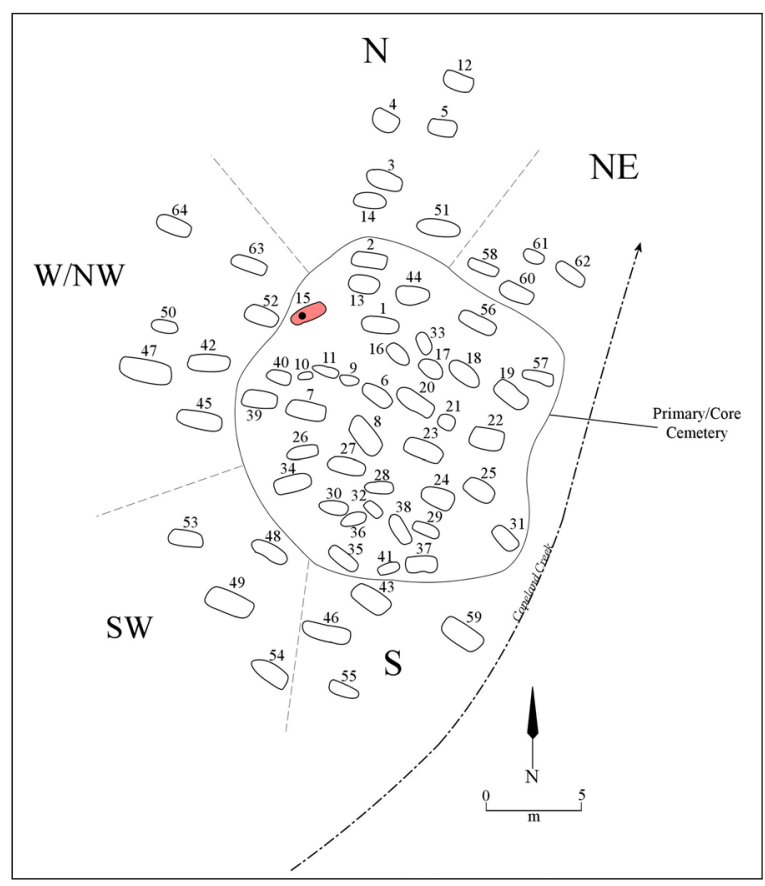

Figure 12. Burials with conjoined vessels at the $\mathrm{H}$. R. Taylor cemetery. 


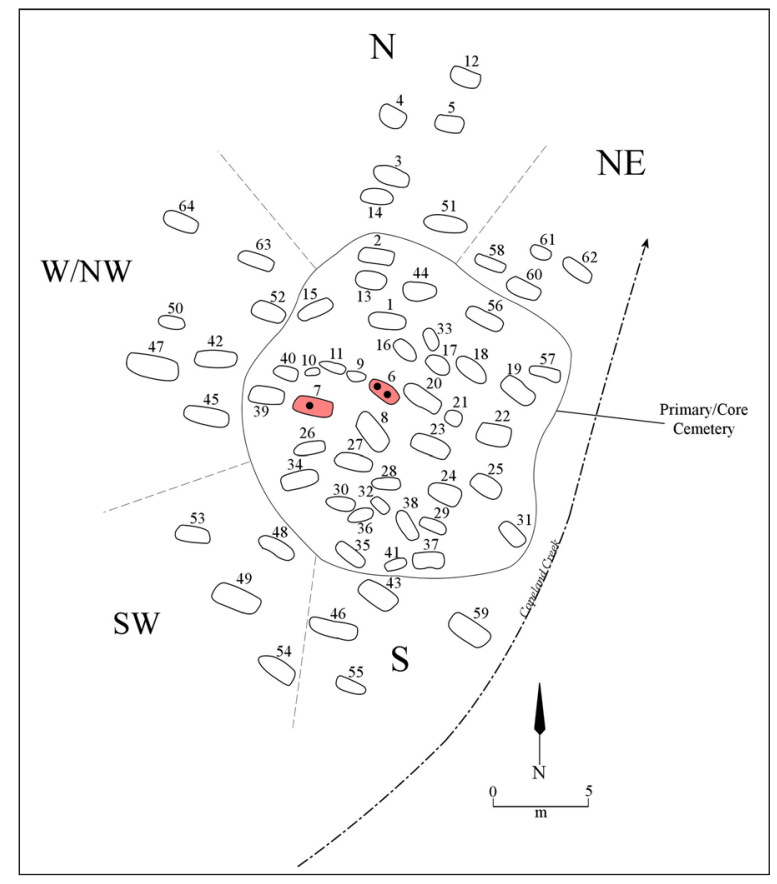

Figure 13. Burials with Moore Noded bowls at the H. R. Taylor cemetery.

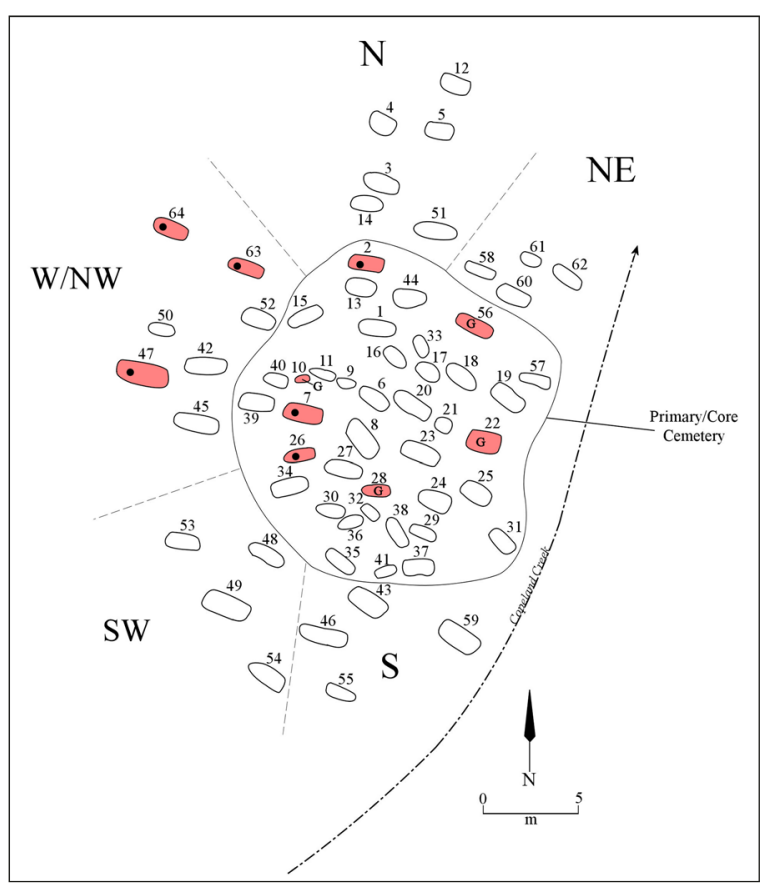

Figure 15. Burials with Glassell Engraved and Simms Engraved vessels at the H. R. Taylor site.

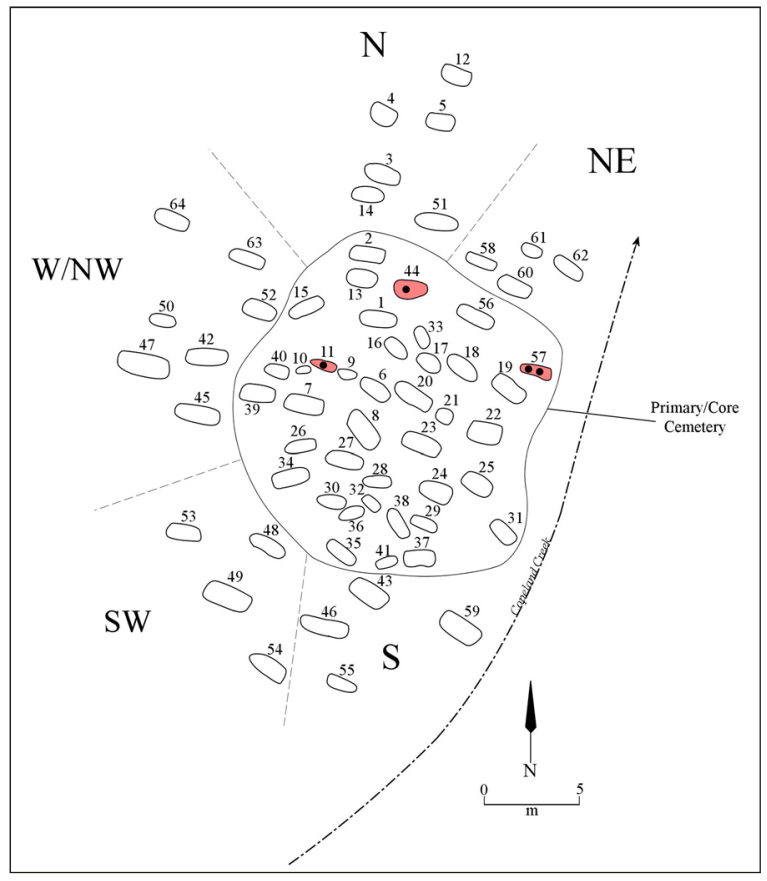

Figure 14. Burials with Ripley Engraved, var. Cash vessels at the H. R. Taylor cemetery.

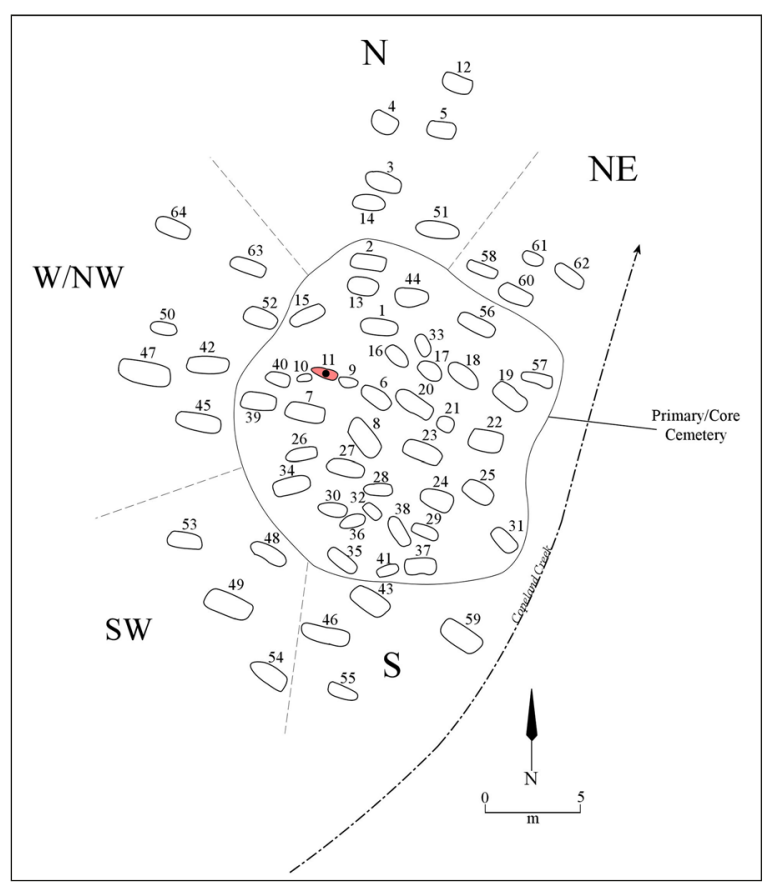

Figure 16. Burial with a Foster Trailed-Incised vessel at the H. R. Taylor site. 
and Wilder Engraved vessels are funerary offerings in burials in all parts of the cemetery, but they are predominant in burials in the northeast, south, and southwest sections (Figures 18 and 19). Burials with the highest density of funerary offerings are predominant in the core, south, southwest, and west/ northwest sections (see Figure 11a).

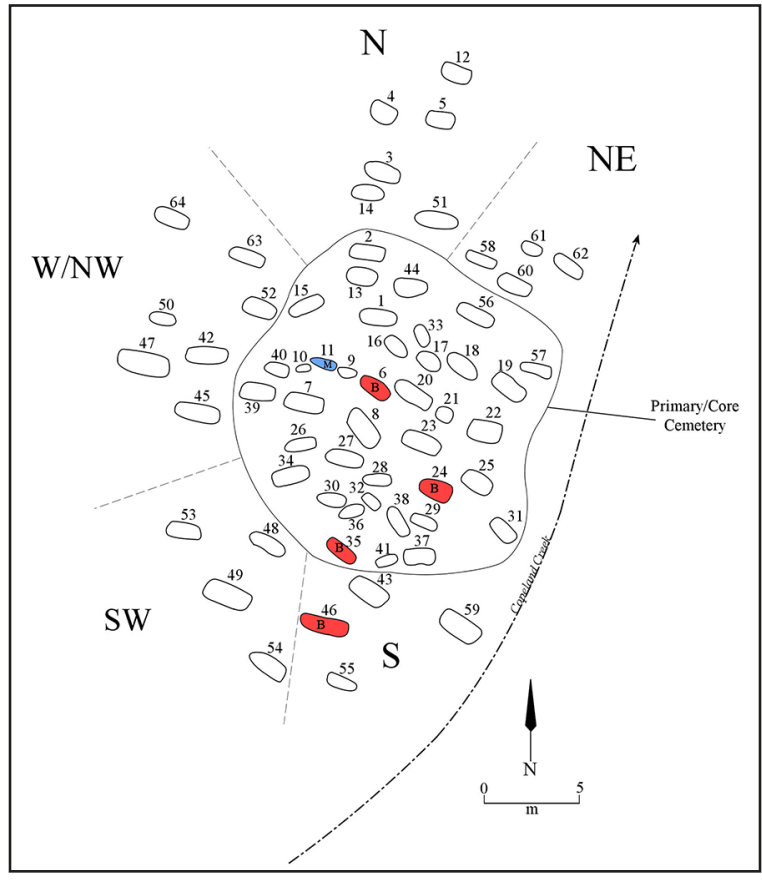

Figure 17. Burials with Maud or Bassett arrow points at the H. R. Taylor site.

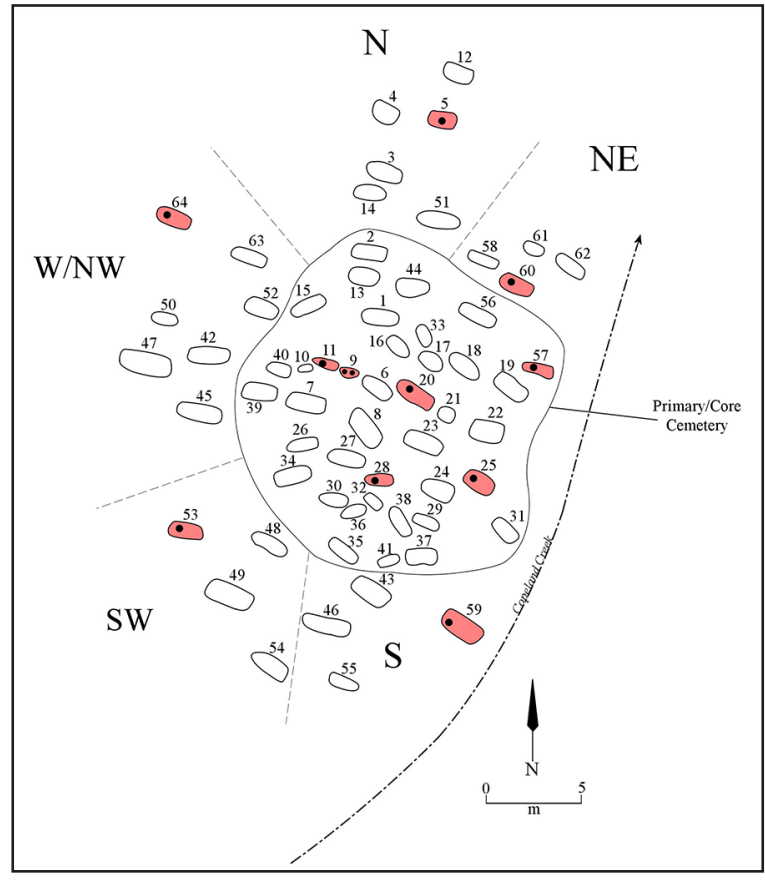

Figure 18. Burials with Ripley Engraved, var. Pilgrims vessels at the H R. Taylor site.

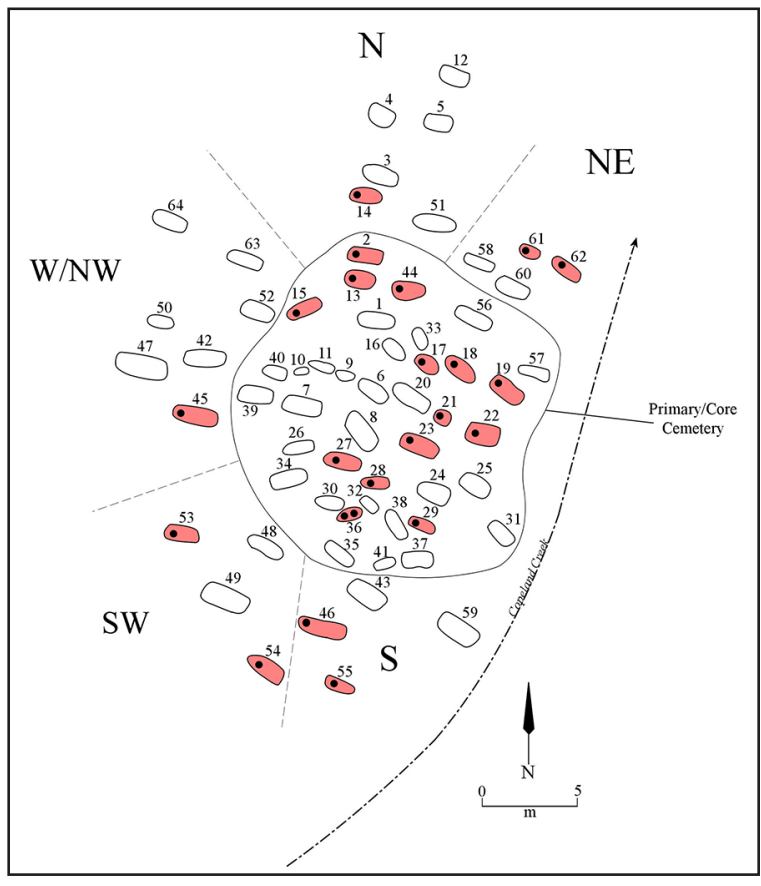

Figure 19. Burials with Wilder Engraved vessels at the H. R. Taylor site. 
Cass Appliqued and Ripley Engraved bottles are proportionally more common in the core and southwestern sections of the H. R. Taylor cemetery (Figures 20 and 21), while plain ware vessels and Bullard Brushed jars are predominant in the core area as well as the west/northwest section (Figures 22 and 23). Arrow points placed on the right side of the body are most common in burials in the core, southwest, and west/northwest sections (Figure 24). Burials with arrow points placed along the left side of the body are more common in the northeast section, and burials with arrow points placed mid-body are more common in the southern section of the cemetery.

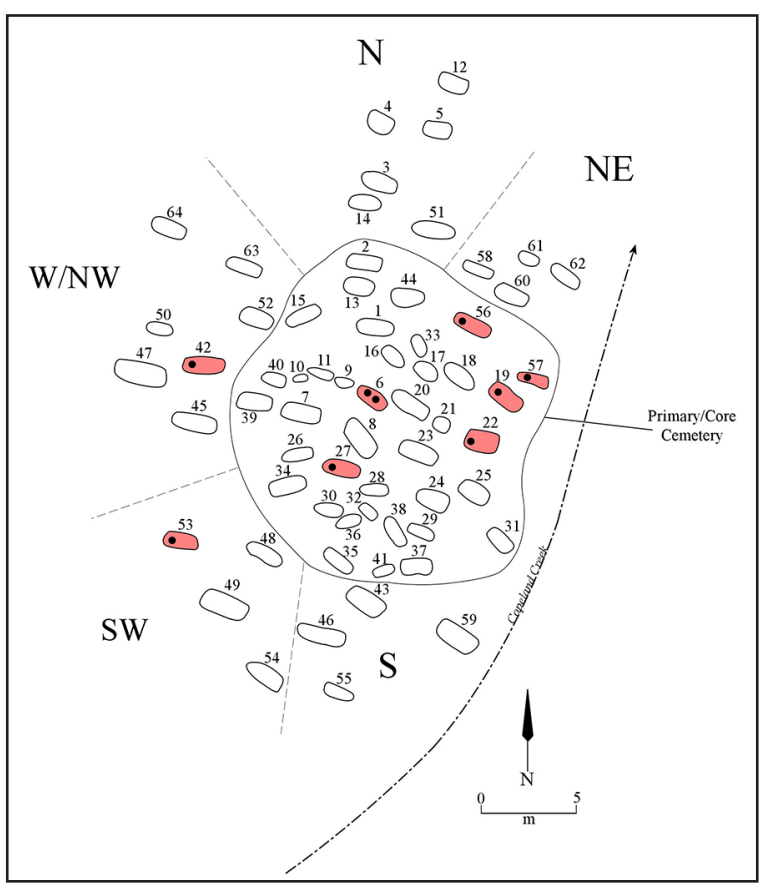

Figure 20. Burials with Cass Appliqued vessels at the H. R. Taylor site.

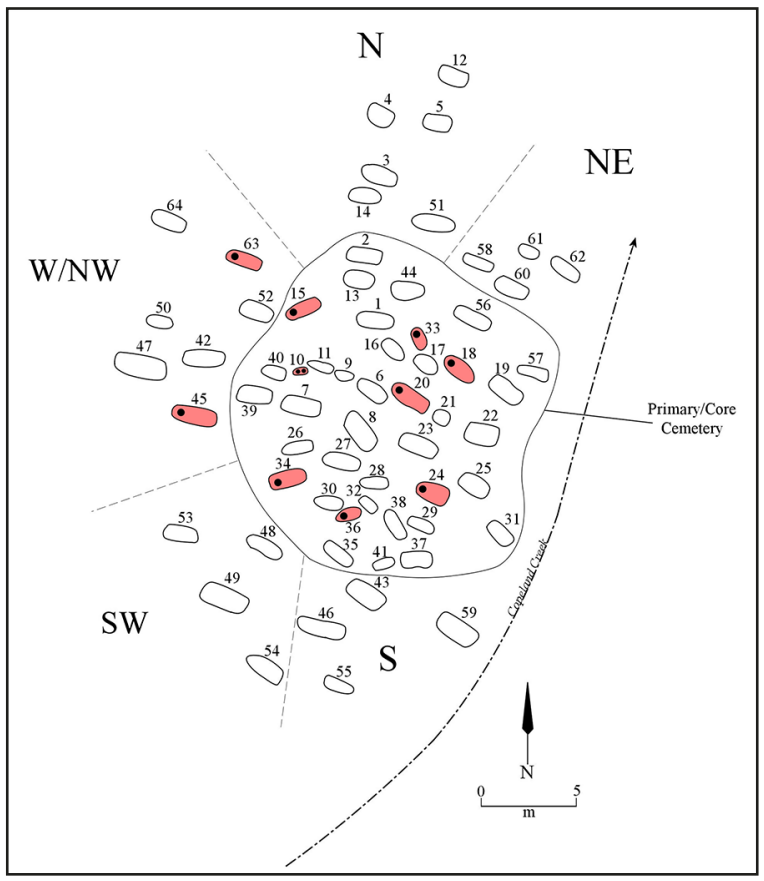

Figure 22. Burials with plain ware vessels at the $\mathrm{H}$. R. Taylor site.

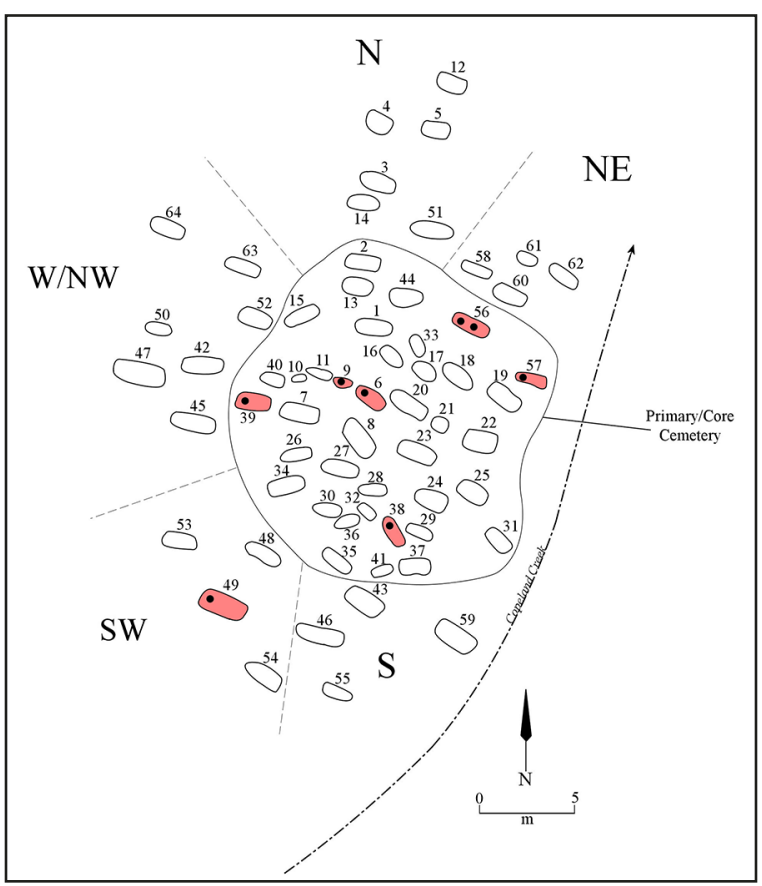

Figure 21. Burials with Ripley Engraved bottles at the H. R. Taylor site.

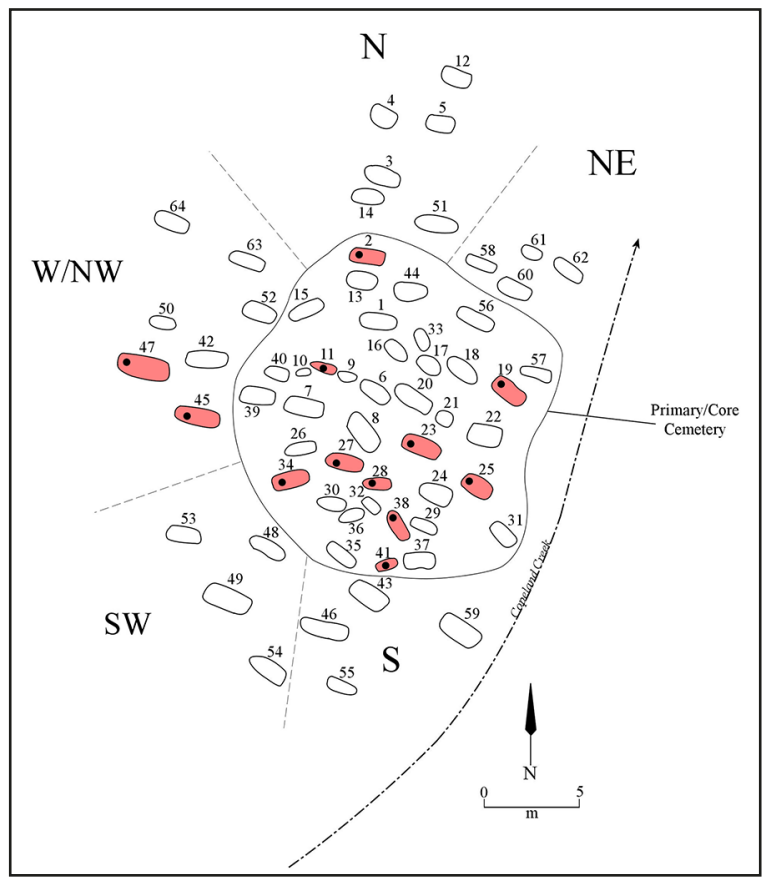

Figure 23. Burials with Bullard Brushed jars at the H. R. Taylor site. 


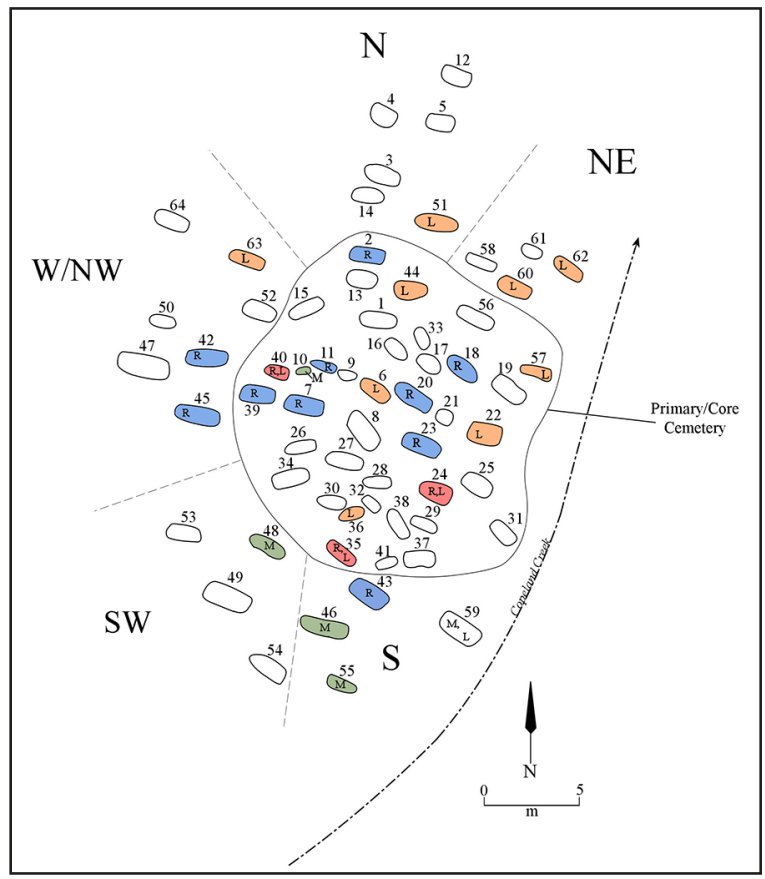

Figure 24. Placement of arrow points in burial features at the H. R. Taylor site.

Certainly, one of the most distinctive attributes of the burials in the northern section of the cemetery is the placement of white sand on the floor of certain features (see Perttula 2018:Figure 10). In terms of funerary offerings, Pease Brushed-Incised, Turner Engraved, and Taylor Engraved bottles are common in the northern section, as well as in the northeast (Figure 25), and west/northwest sections (Figures 26 and 27). Taylor Engraved bottles were funerary offerings in all parts of the cemetery. Taylor Engraved

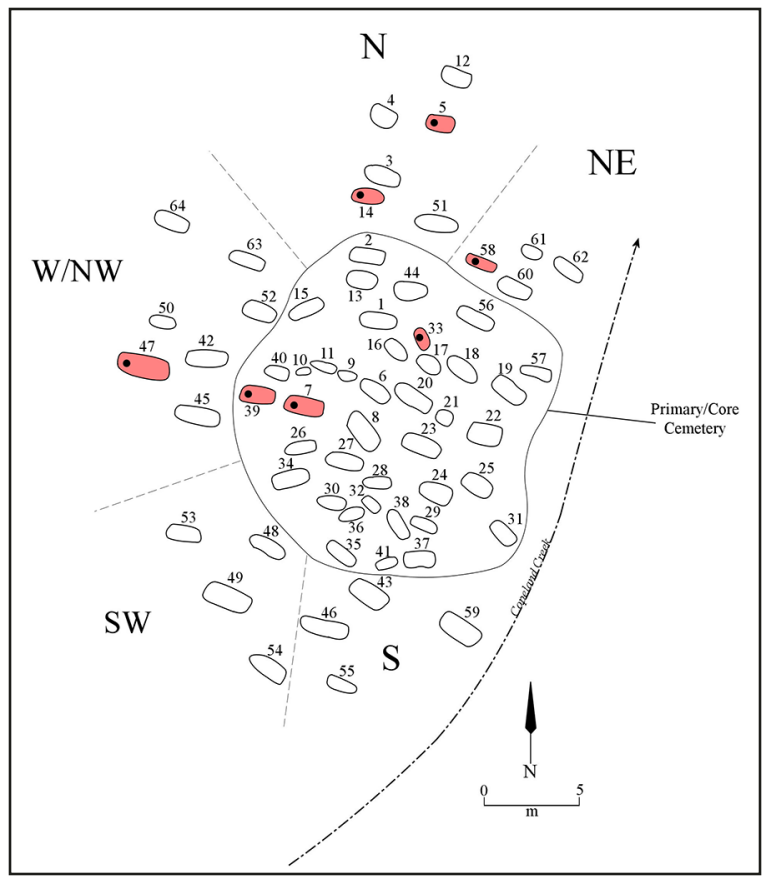

Figure 25. Burials with Pease Brushed-Incised vessels at the H. R. Taylor site.

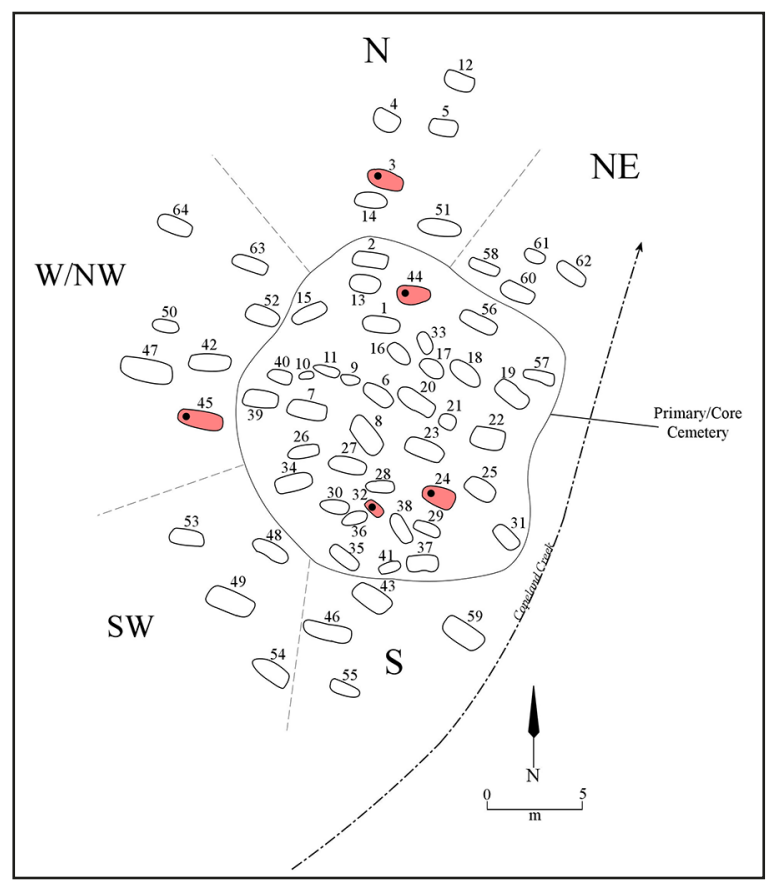

Figure 26. Burials with Turner Engraved vessels at the H. R. Taylor site. 


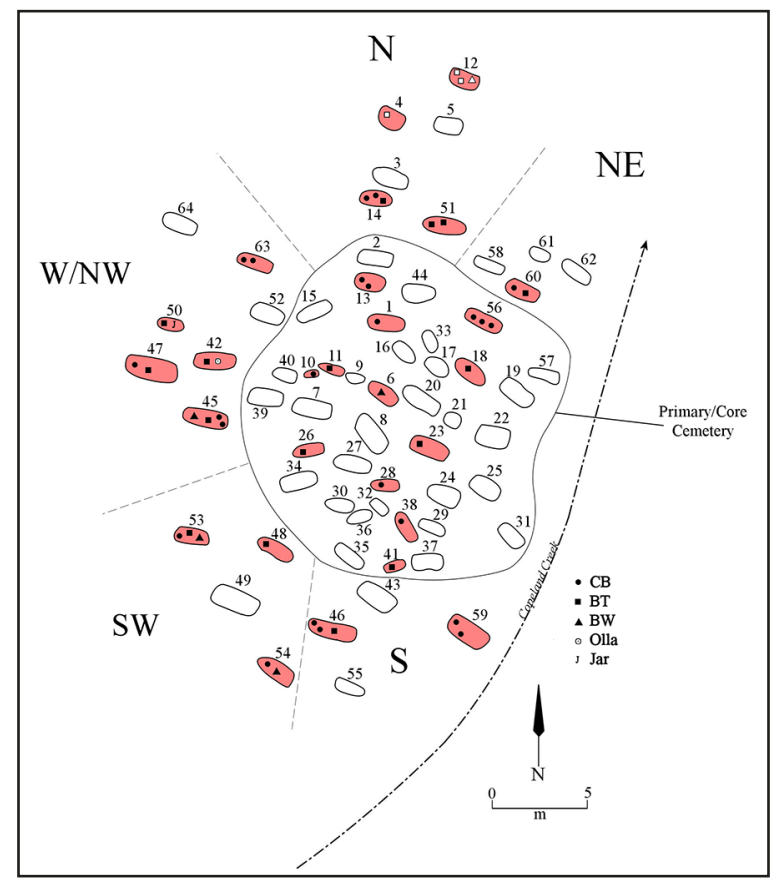

Figure 27. Burials with Taylor Engraved carinated bowls, bottles, bowls, ollas, and jars at the H. R. Taylor site.

carinated bowls are also funerary offerings in all parts of the cemetery, although placed most commonly in burials in the southern area. Bowls are most commonly placed in burials in the southwest section, and ollas and jars are more common funerary offerings in the west/northwest sections.

In the northeast section of the cemetery at the H. R. Taylor site, predominant funerary offerings include Ripley Engraved, var. Gandy vessels (Figure 28), Ripley Engraved, var. McKinney-Enis Smith (Figure 29), and Ripley Engraved, var. Williams vessels (Figure 30). Other important funerary offerings most common in this section of the cemetery are shell-tempered vessels (Figure 31), Bowie Engraved vessels (Figure 32), and engraved/trailed jars (Figure 33).

Red clay pigments rubbed into engraved designs on vessels are proportionally most common in the northeast section of the cemetery (Figure 34). A white clay pigment was used on vessels in all parts of the cemetery, but are particularly common in the south, southwest, and west/northwest areas; these areas are thought to be amongst the youngest in the H. R. Taylor cemetery.

Ripley Engraved carinated bowls are common funerary offerings in burials throughout the H. R. Taylor site cemetery (Figure 35). They are proportionally most common, however, in the northeast, south, southwest, and west/northwest sections.

Both paint stones (i.e., red ochre) and clay masses placed in burials as funerary offerings are proportionally most common in both the northeast and southwest sections of the cemetery (see Perttula 2018:Figures 9 and 14). Bailey Engraved bottle are most common in the northeast and west/northwest sections (Figure 36). 


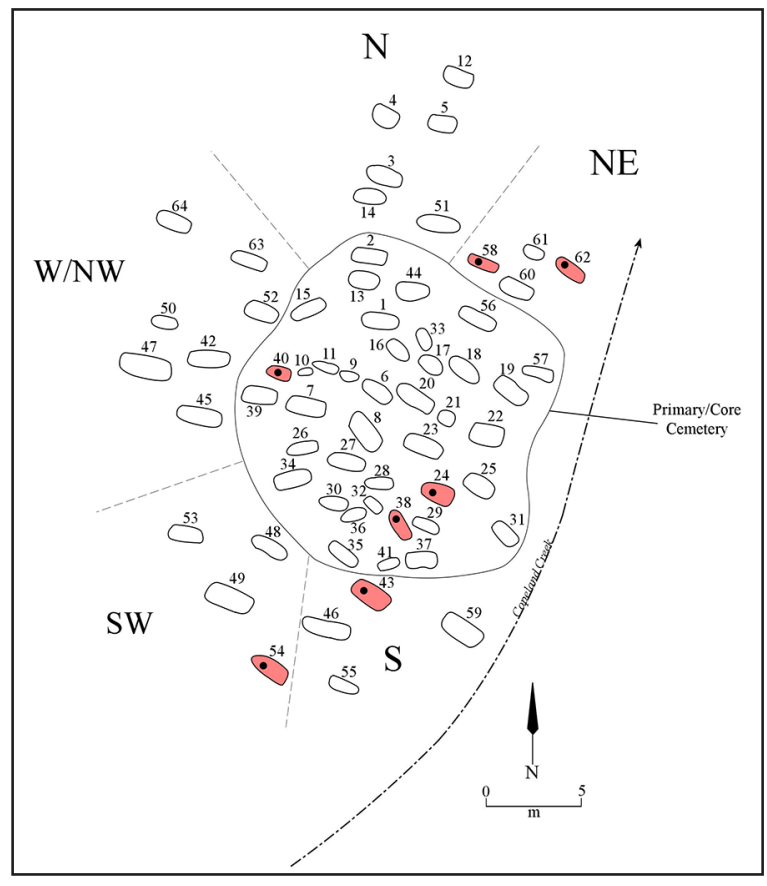

Figure 28. Burials with Ripley Engraved, var. Gandy vessels at the H. R. Taylor site.

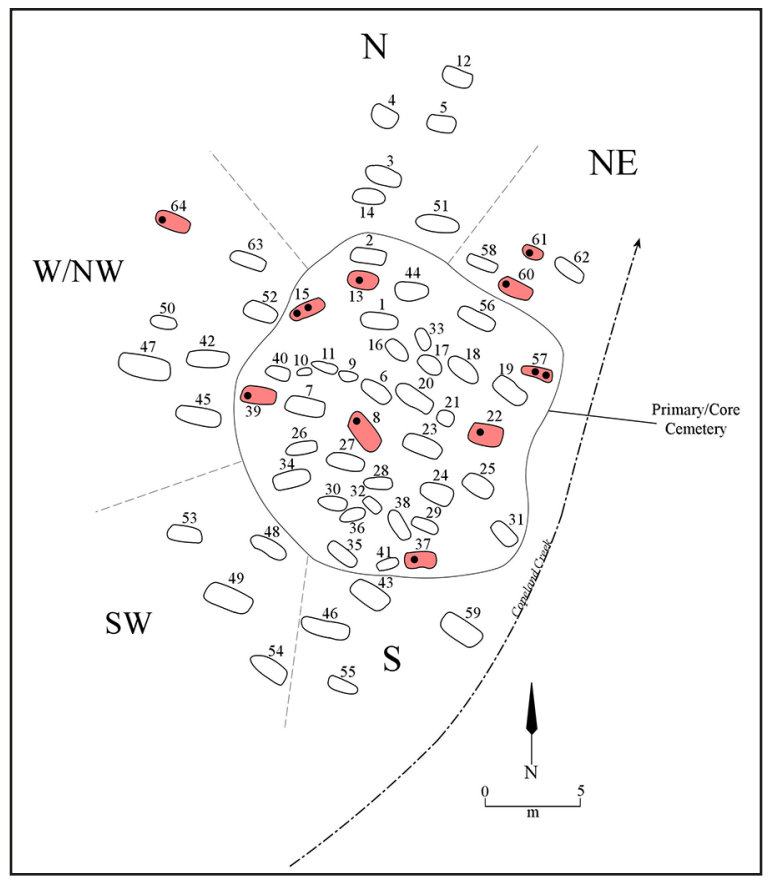

Figure 30. Burials with Ripley Engraved, var. Williams vessels at the H. R. Taylor site.

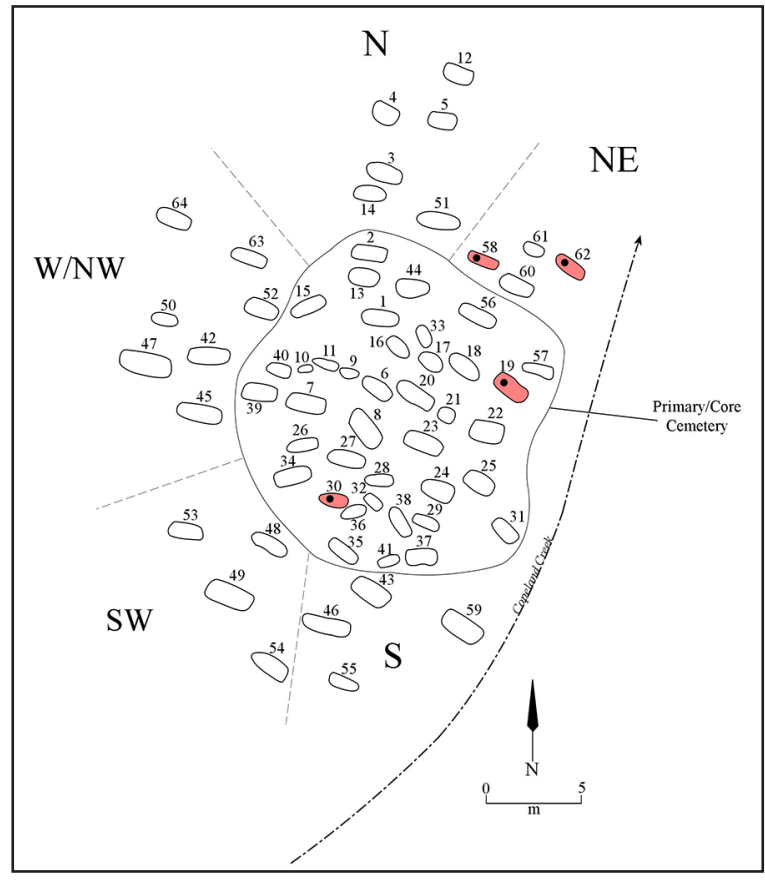

Figure 29. Burials with Ripley Engraved, var. McKinney-Enis Smith vessels at the H. R. Taylor site.

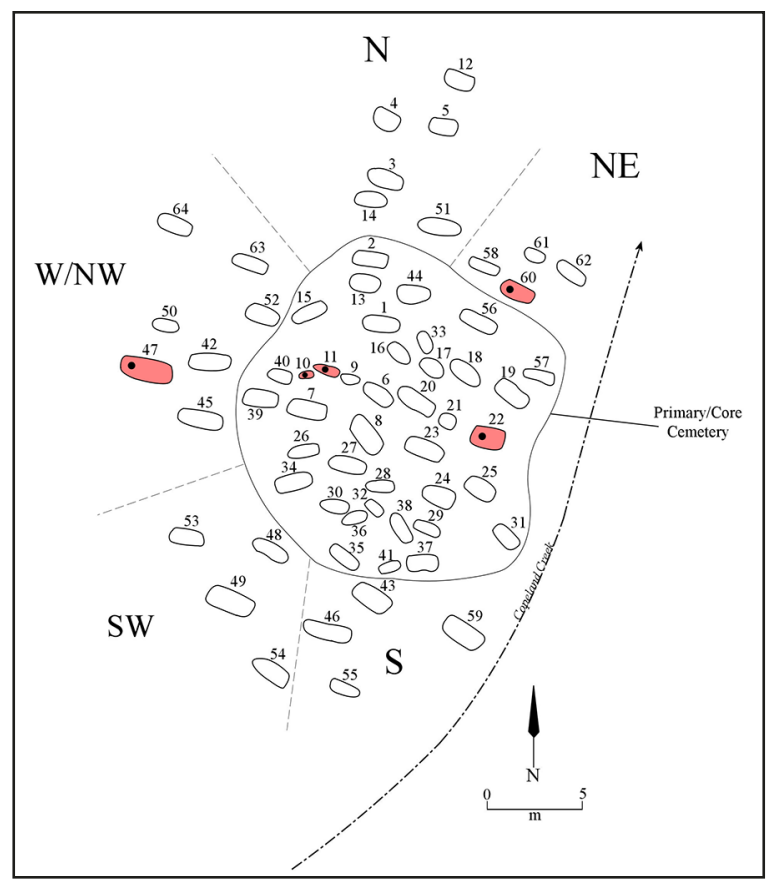

Figure 31. Burials with shell-tempered vessels at the H. R. Taylor cemetery. 


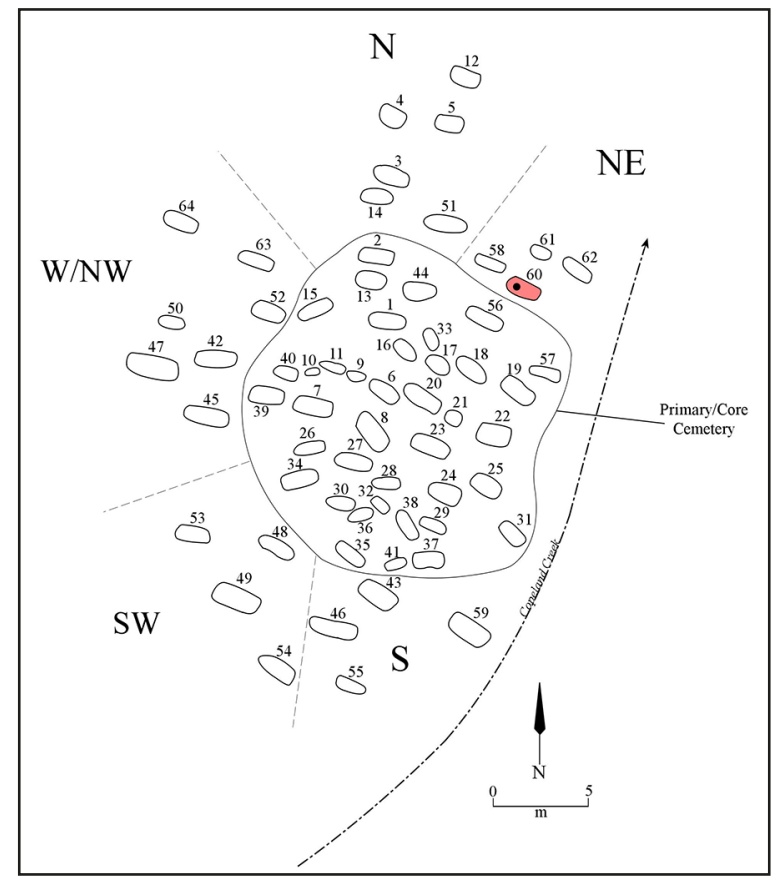

Figure 32. Burial with Bowie Engraved vessel at the H. R. Taylor cemetery.

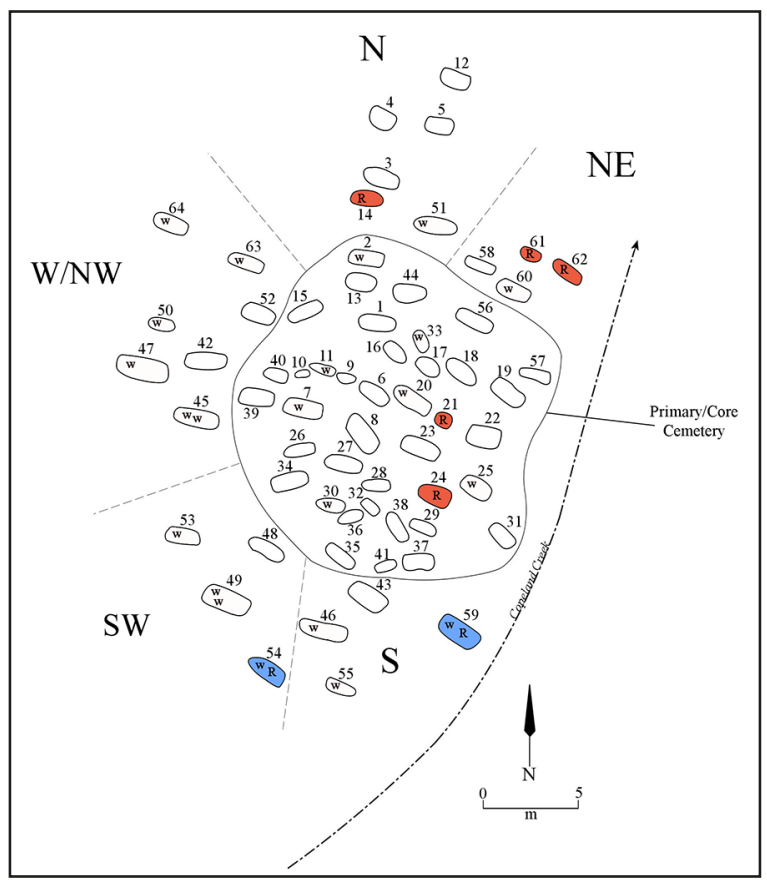

Figure 34. Burials with vessels with either red or white pigment rubbed in the engraved lines at the H. R. Taylor site.

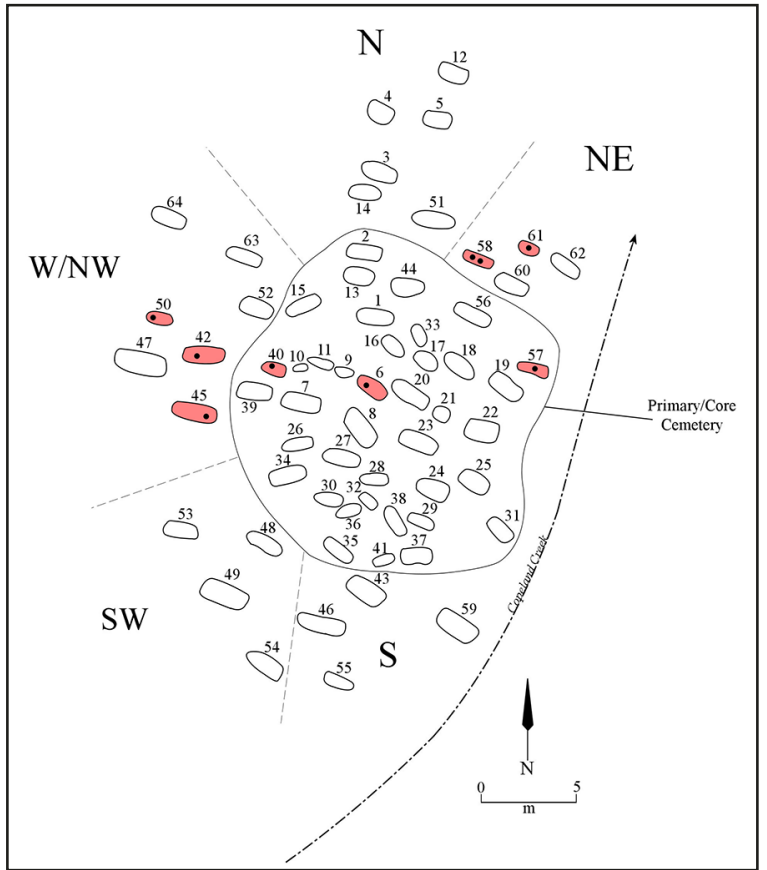

Figure 33. Burials with engraved or trailed jars at the H. R. Taylor site.

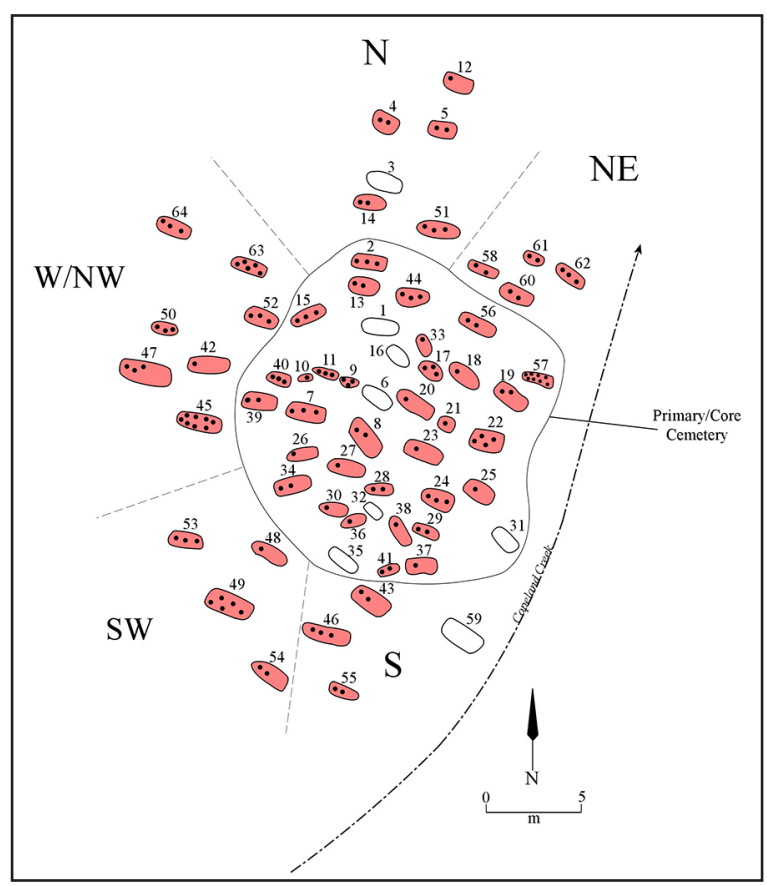

Figure 35. Burials with Ripley Engraved carinated bowls at the H. R. Taylor site. 


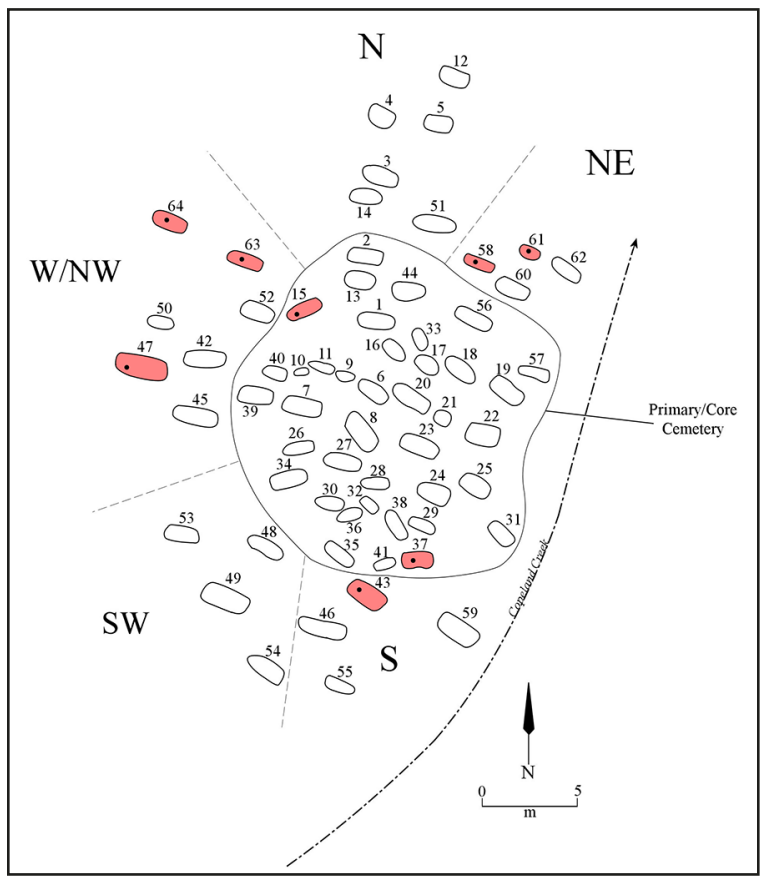

Figure 36. Burials with Bailey Engraved bottles in the H. R. Taylor cemetery.

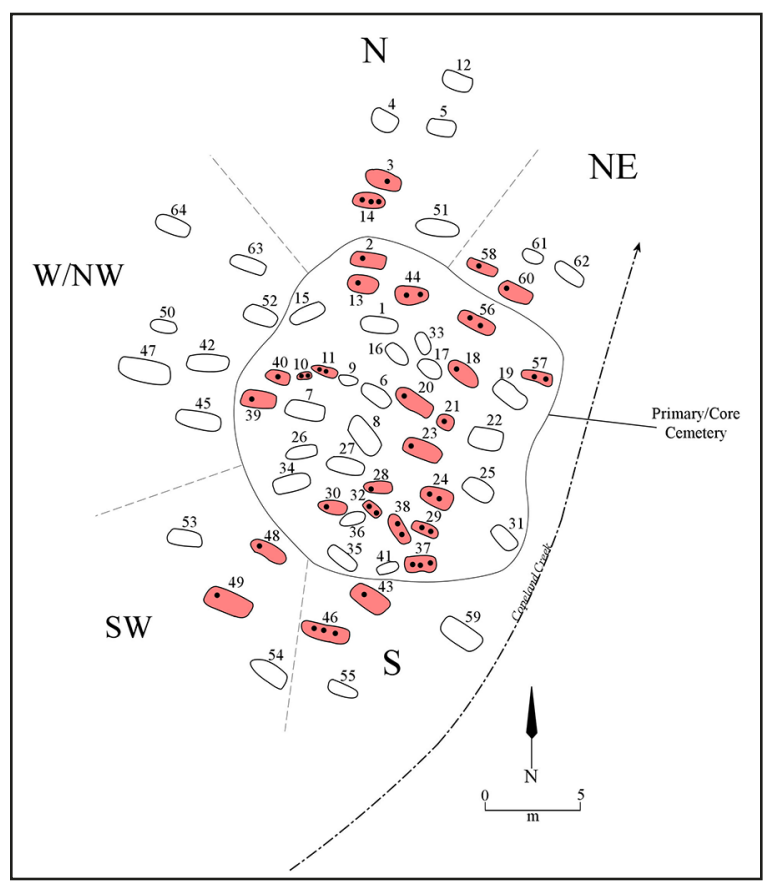

Figure 37. Burials with Karnack Brushed-Incised vessels in the H. R. Taylor cemetery.
In the southern section of the cemetery, funerary offerings proportionally most common there include burials with more than 10 arrow points (see Perttula 2018:Figure 13), points placed by the mid-body, and Karnack Brushed-Incised and Maydelle Incised jars (Figures 37 and 38). Ripley Engraved, var. Carpenter vessels occur most frequently in the south, southwest, and west/ northwest sections (Figure 39), as does the use of white pigment rubbed in the engraved lines of fine ware vessels.

Keno Trailed vessels likely made after ca. A.D. 1680 (see Schambach and Miller 1984:123) occur only in the south and west/northwest sections (Figure 40) of the cemetery. These are likely the areas with the latest and youngest burials at the $\mathrm{H}$. $\mathrm{R}$. Taylor site. These same areas have burials with the highest frequency of ceramic vessel funerary offerings (see Figure 12).

Taylor Engraved carinated bowls and Talco arrow points are found as funerary offerings in burials in all areas of the cemetery. However, they are proportionally most common in the southern cemetery section (Figure 41; see also Figure 27).

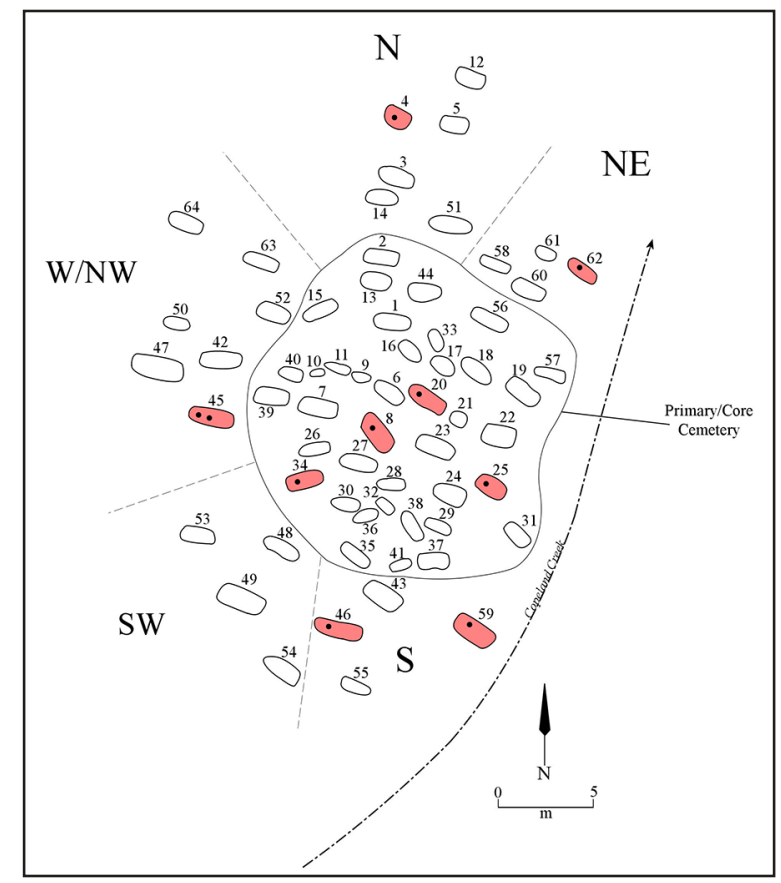

Figure 38. Burials with Maydelle Incised vessels in the H. R. Taylor cemetery. 


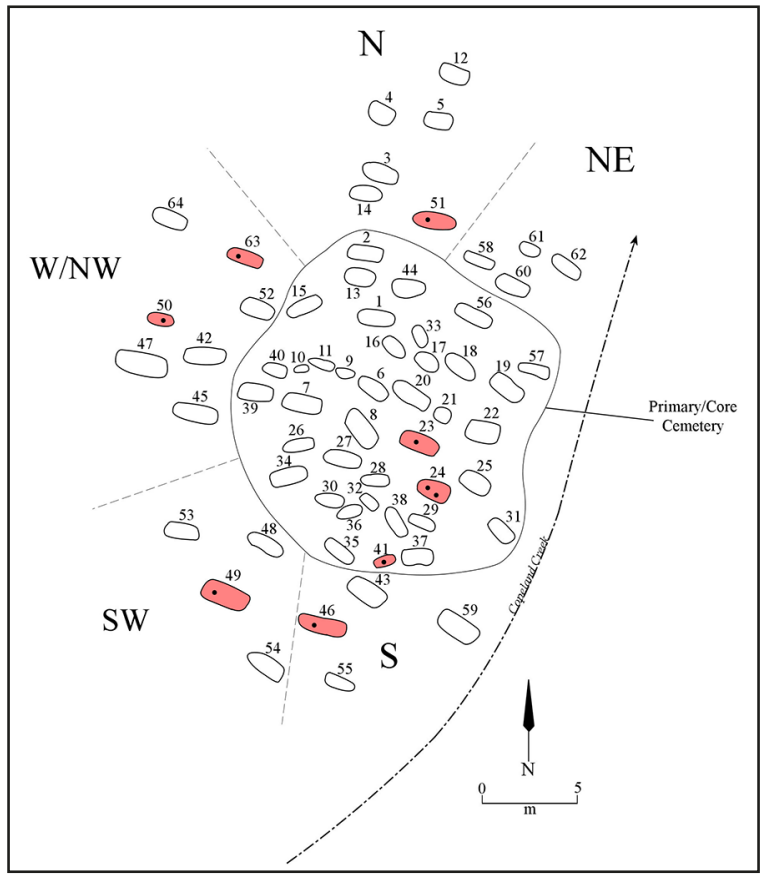

Figure 39. Burials with Ripley Engraved, var. Carpenter vessels in the H. R. Taylor cemetery.

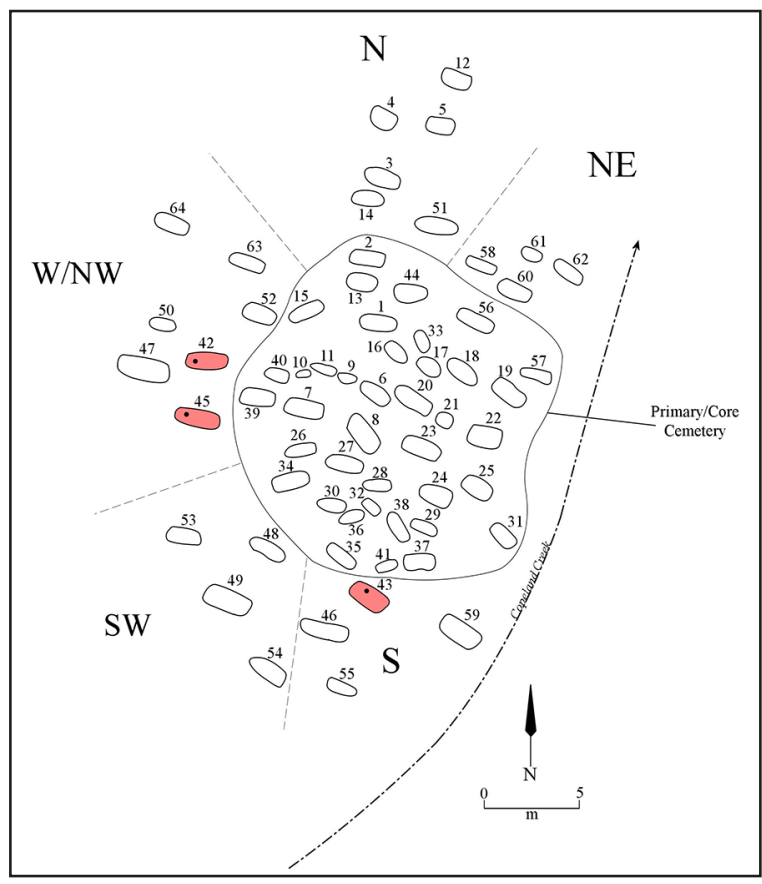

Figure 40. Burials with Keno Trailed vessels in the H. R. Taylor cemetery.

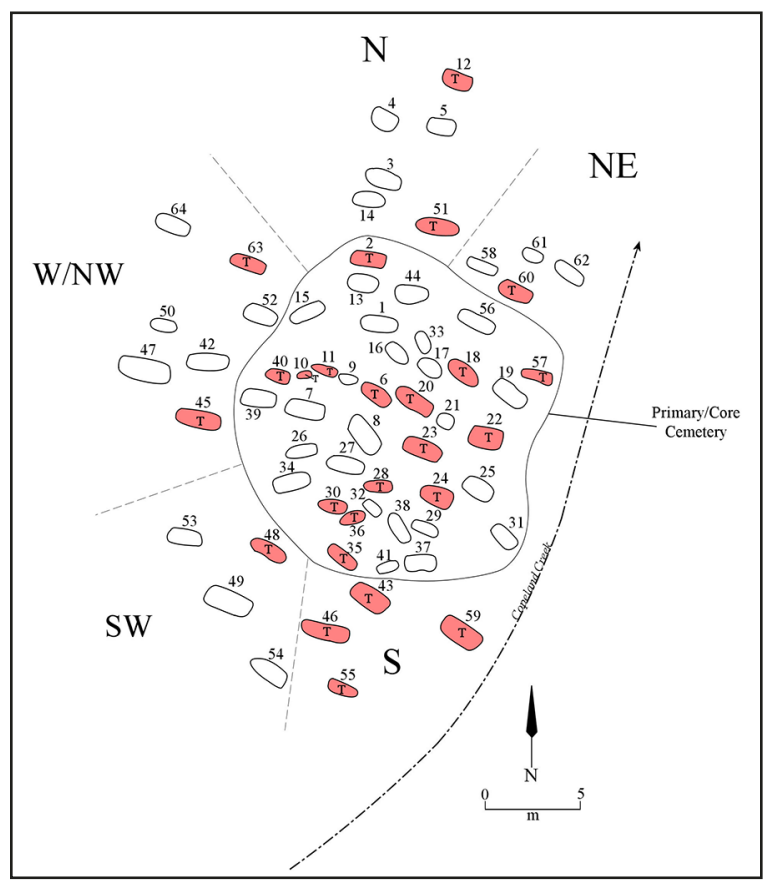

Figure 41. Burials with Talco arrow points in the H. R. Taylor cemetery. 
Celts, a Galt biface, and ceramic ear spools are most common as funerary offerings in the southwest section of the cemetery (see Perttula 2018:Figures 15-17). So too are Belcher Engraved vessels (Figure 42), extra-large compound bowls (Figure 43), Ripley Engraved, var. Caldwell vessels (Figure 44), and Taylor Engraved bowls (see Figure 27). Vessels with rounded bases occur in burial features in all parts of the cemetery, but are most common proportionally in the southwest section (Figure 45).

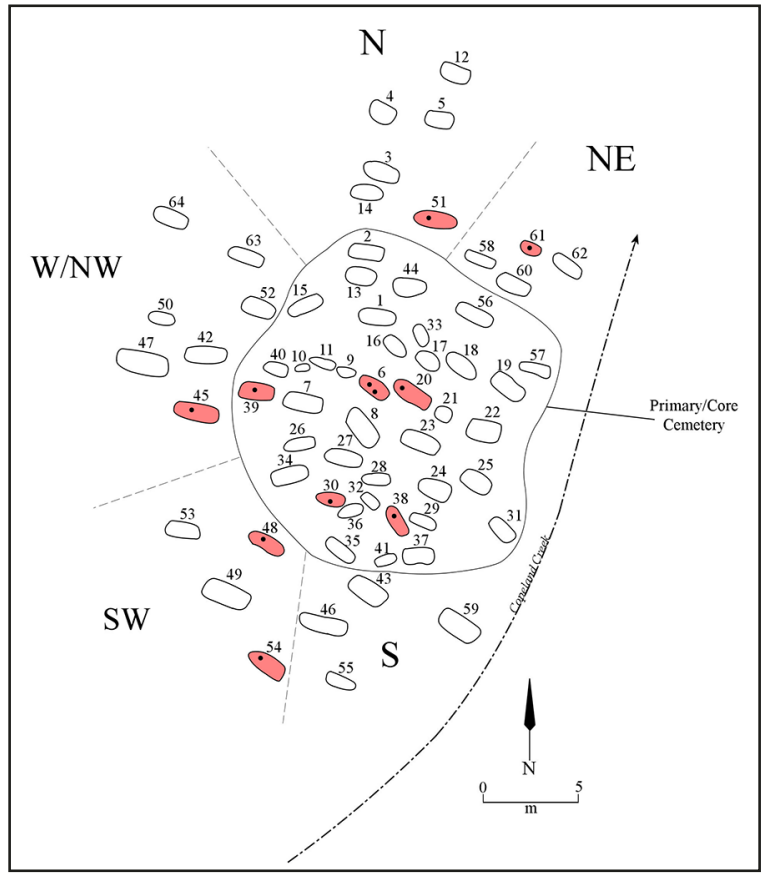

Figure 42. Burials with Belcher Engraved vessels in the H. R. Taylor cemetery.

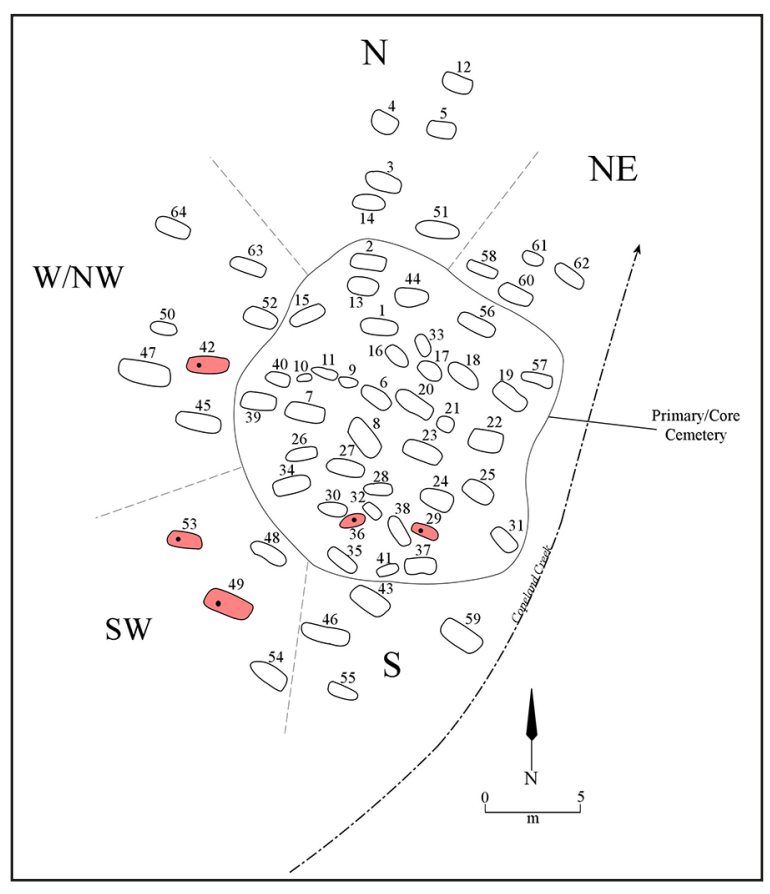

Figure 44. Burials with Ripley Engraved, var. Caldwell vessels in the H. R. Taylor cemetery.

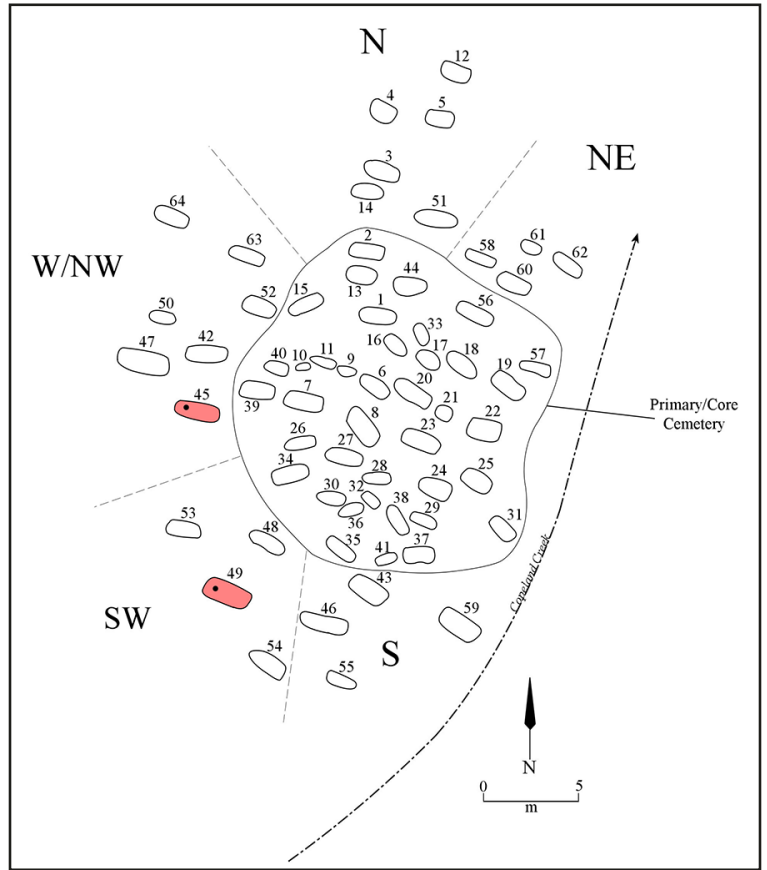

Figure 43. Burials with extra-large compound bowls in the H. R. Taylor cemetery.

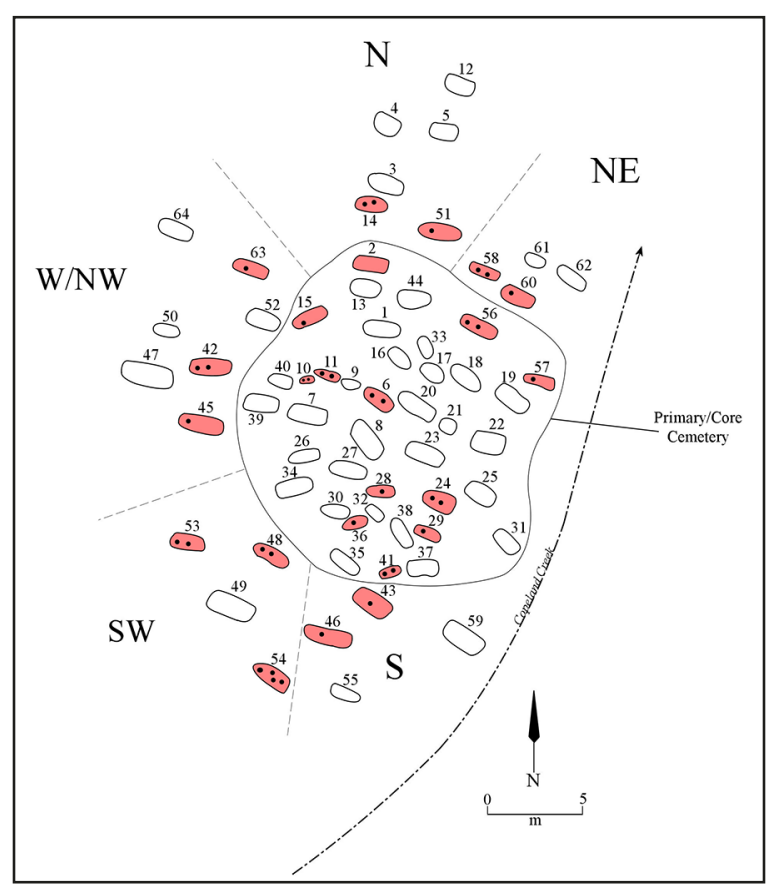

Figure 45. Burials with vessels with rounded bases in the H. R. Taylor cemetery. 
Hodges Engraved vessels are best represented in burial features in the southwest and west/ northwest sections (Figure 46). It is not a common funerary offering in any cemetery area, however.

Burial features in the west/northwest section of the H. R. Taylor cemetery have more evidence of fire in the burial pits than do other sections (see Perttula 2018:Figure 11). The only quartz crystal placed in a burial was found in a west/northwest burial feature (see Perttula 2018:Figure 16). Ceramic pipes were most common in Burial 45 (see Perttula 2018:Figure 18).

Ceramic vessels that are proportionally more abundant funerary offerings in the west/northwest section include extra-large carinated bowls (Figure 47), ollas (Figure 48), effigy bowls (Figure 49), miniature vessels (Figure 50), and vessels made with bone temper (Figure 51). Utility ware vessels most common in the west/northwest cemetery section are Belcher Ridged (Figure 52), Harleton Appliqued (Figure 53), La Rue Neck Banded (Figure 54), and unidentified utility ware (Figure 55).

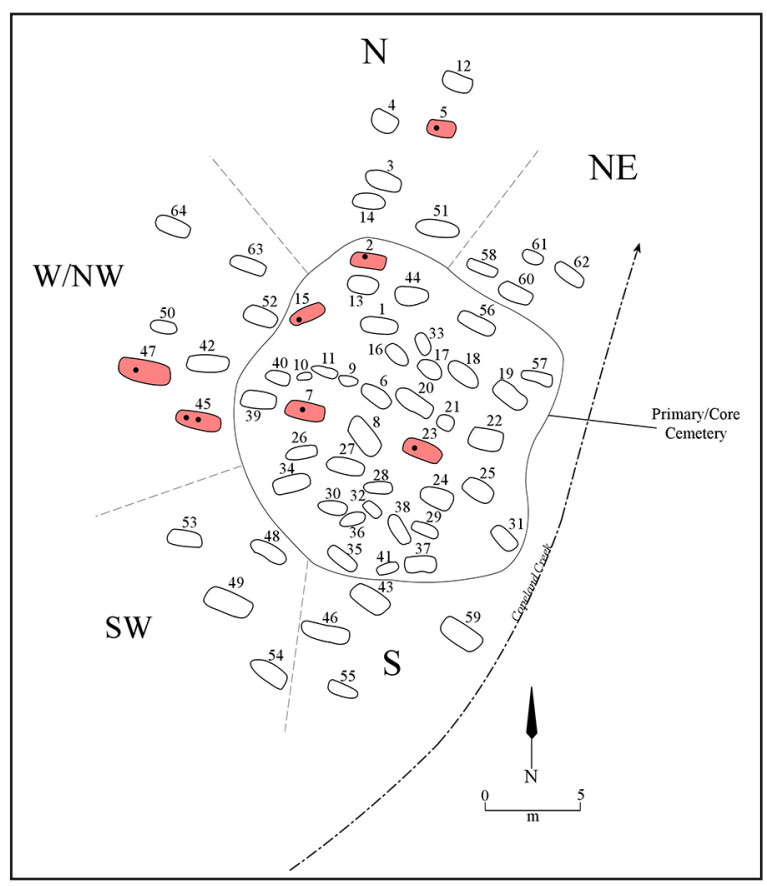

Figure 47. Burials with extra-large carinated bowls in the H. R. Taylor cemetery.

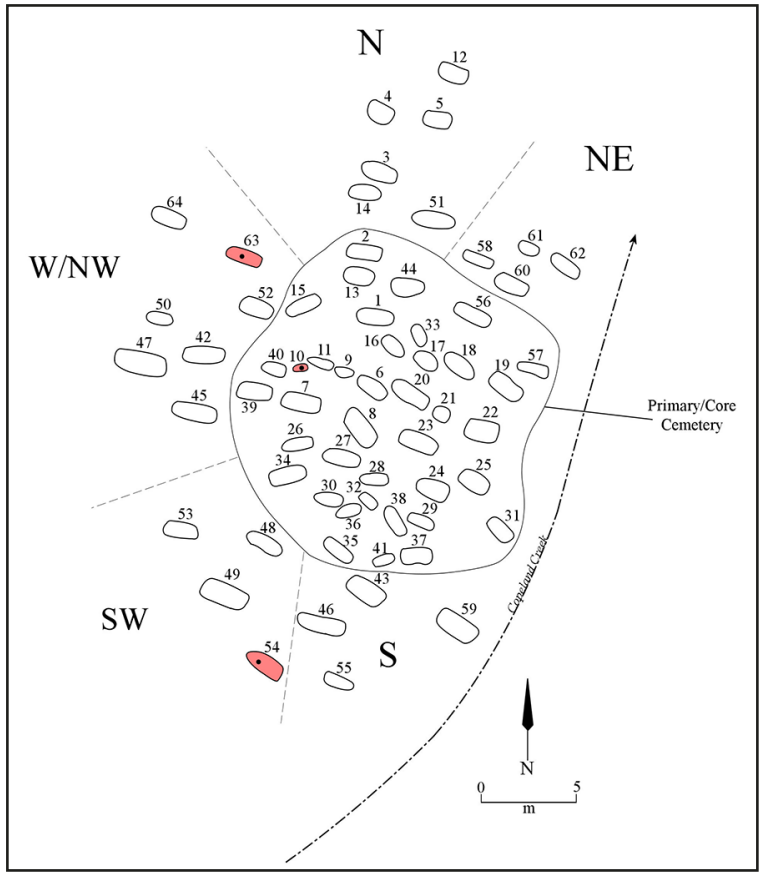

Figure 46. Burials with Hodges Engraved vessels in the H. R. Taylor cemetery.

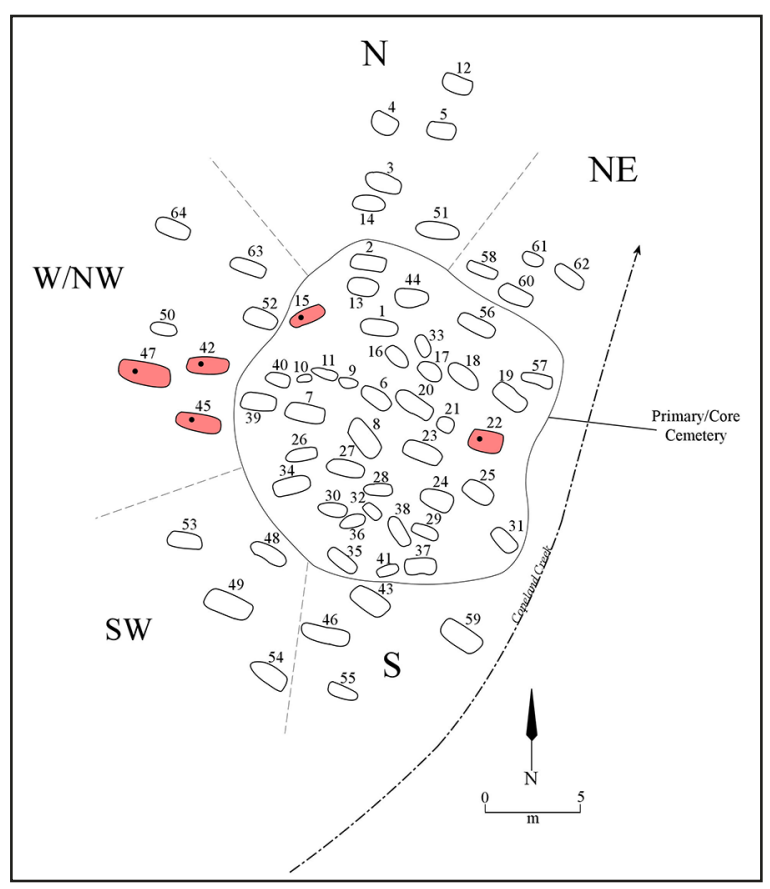

Figure 48. Burials with ollas in the H. R. Taylor cemetery. 


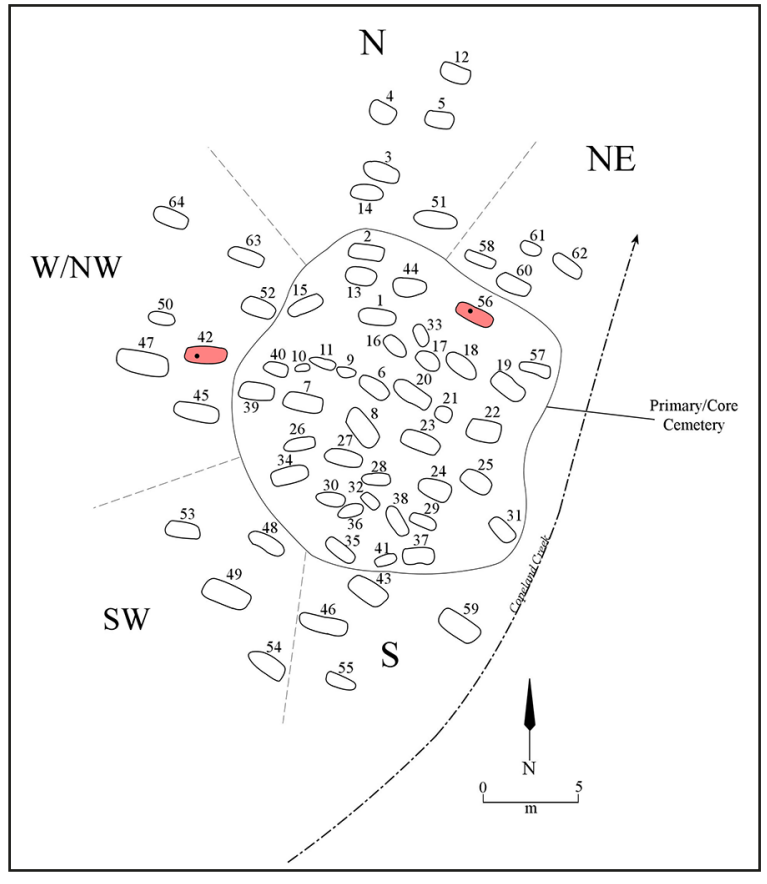

Figure 49. Burials with effigy bowls in the H. R. Taylor cemetery.

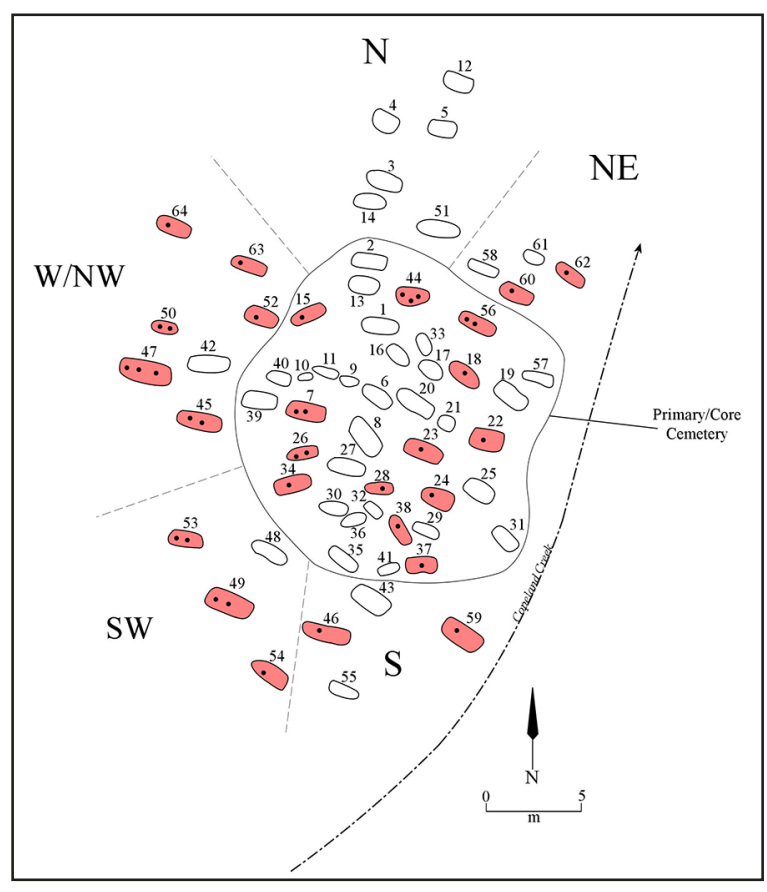

Figure 51. Burials with bone-tempered vessels in the H. R. Taylor cemetery.

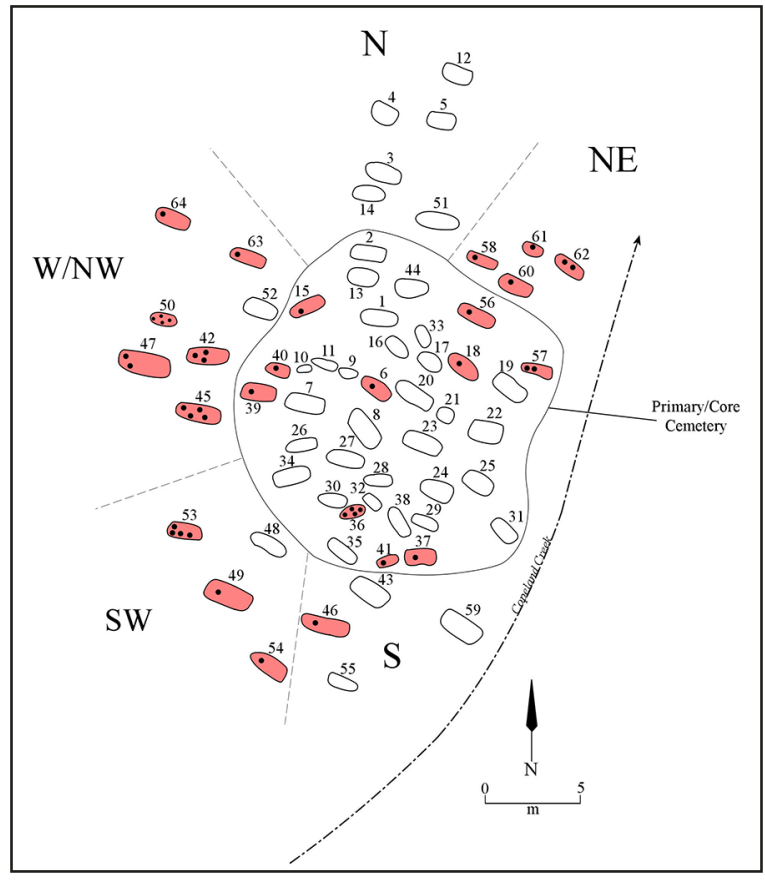

Figure 50. Burials with miniature vessels in the $\mathrm{H}$. R. Taylor cemetery.

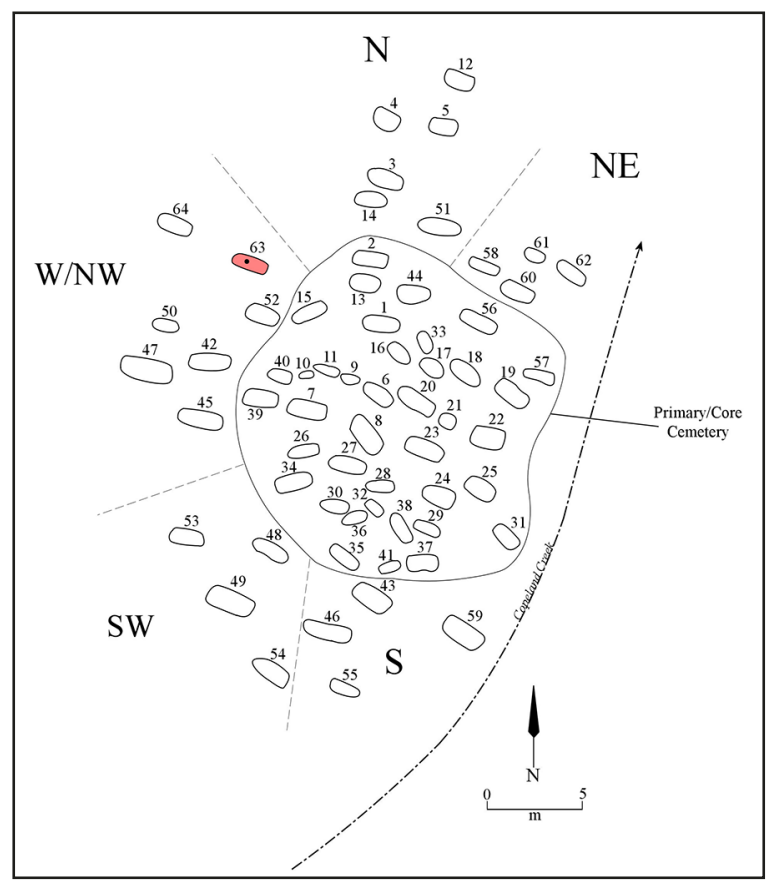

Figure 52. Burial with Belcher Ridged vessel in the H. R. Taylor cemetery. 


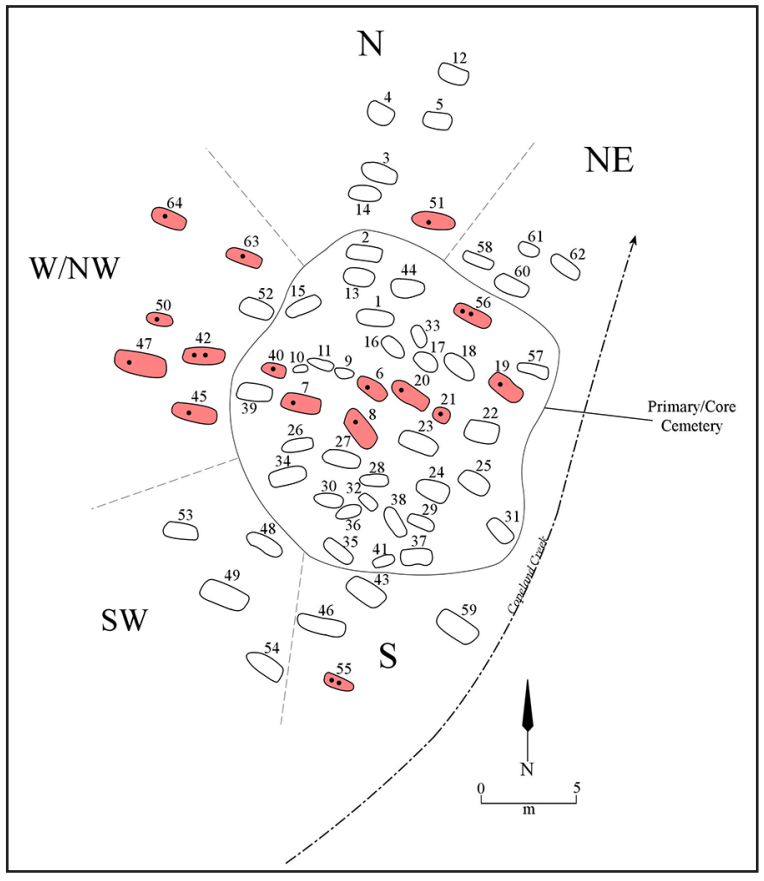

Figure 53. Burials with Harleton Appliqued vessels in the H. R. Taylor cemetery.

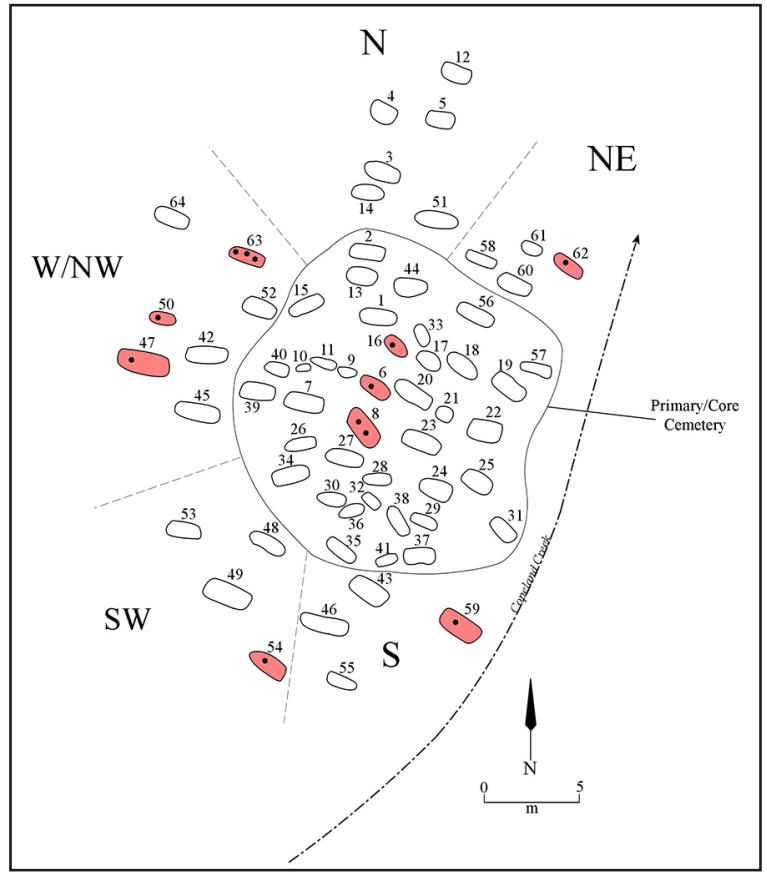

Figure 54. Burials with La Rue Neck Banded vessels in the H. R. Taylor cemetery.

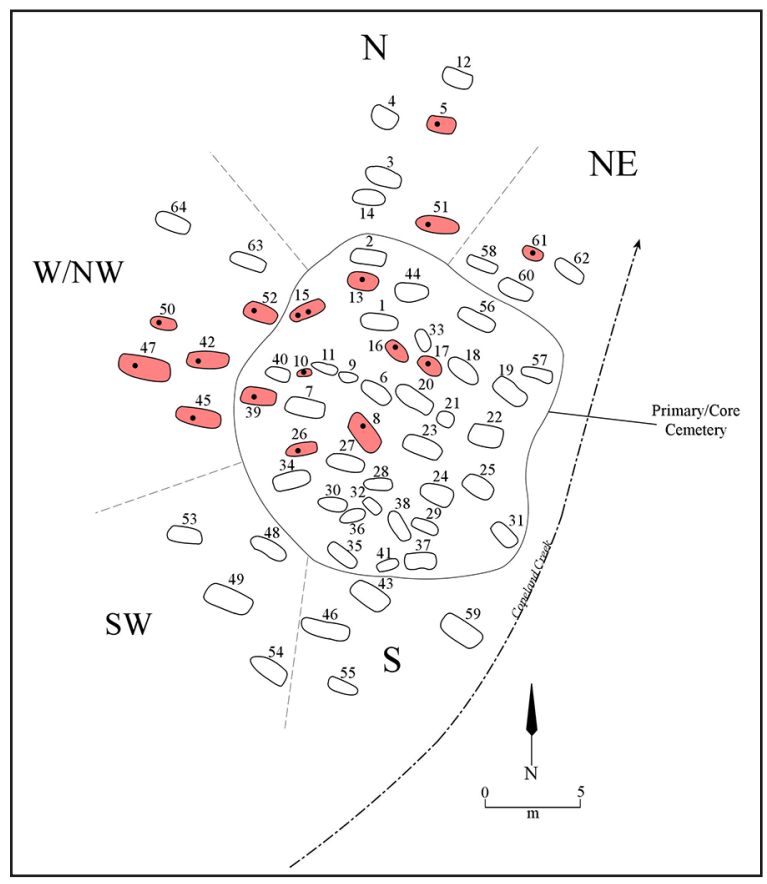

Figure 55. Burials with unidentified utility ware vessels in the H. R. Taylor cemetery. 
A number of fine ware vessel types and forms are notably common in the west/northwest section of the H. R. Taylor cemetery (see Table 13). Among them are Ripley Engraved, var. unspecified (Figure 56), Patton Engraved (Figure 57), red-slipped vessels (Figure 58), Taylor Engraved ollas and jars (see Figure 27), fine ware vessels with multiple and different engraved motifs on rim-body or upper-lower rim panels on carinated bowls and compound bowls (Figure 59), and unidentified fine ware (Figure 60).

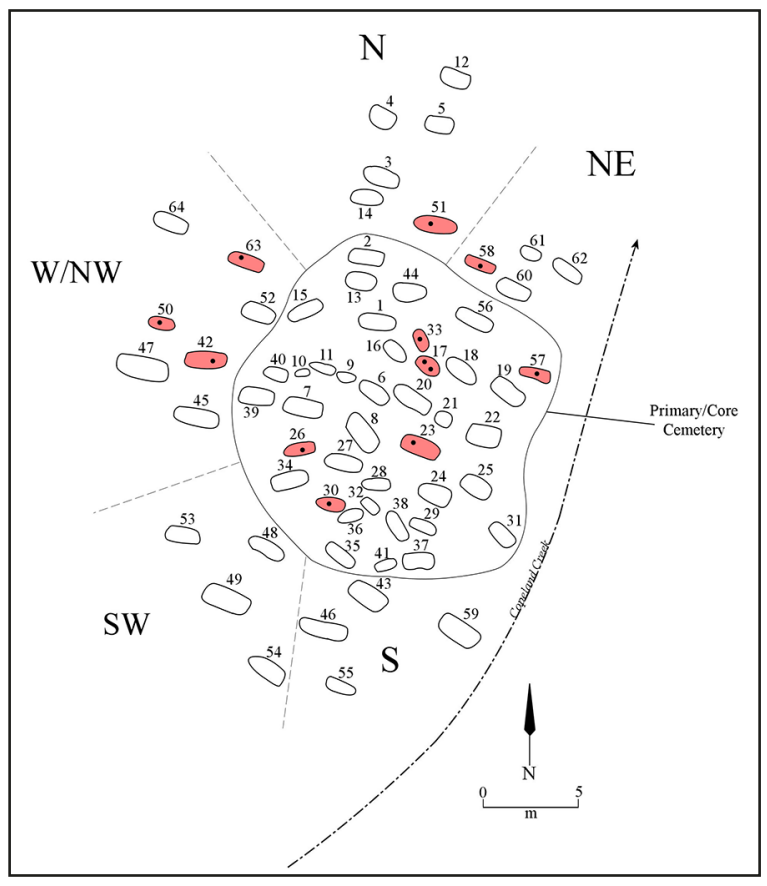

Figure 56. Burials with Ripley Engraved, var. unspecified vessels in the H. R. Taylor cemetery.

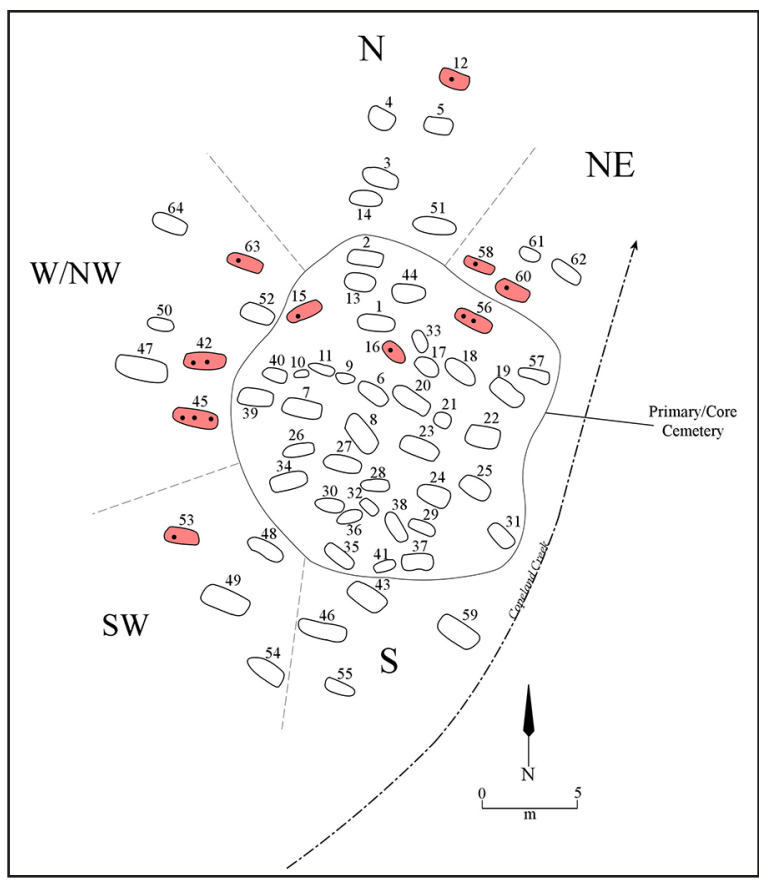

Figure 58. Burials with red-slipped vessels in the H. R. Taylor cemetery.

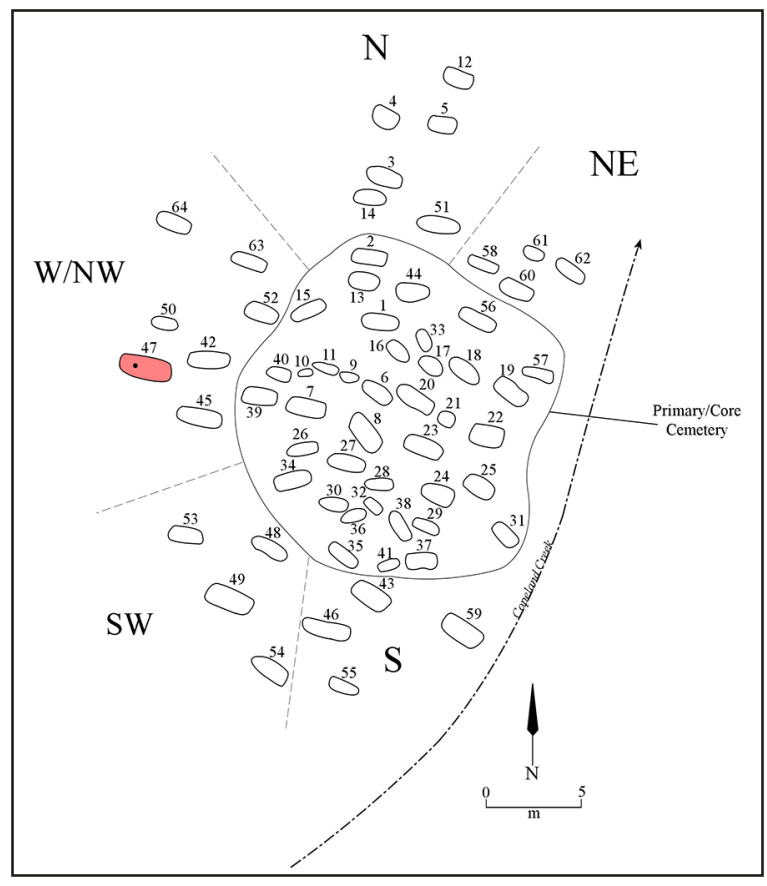

Figure 57. Burial with Patton Engraved vessel in the H. R. Taylor cemetery.

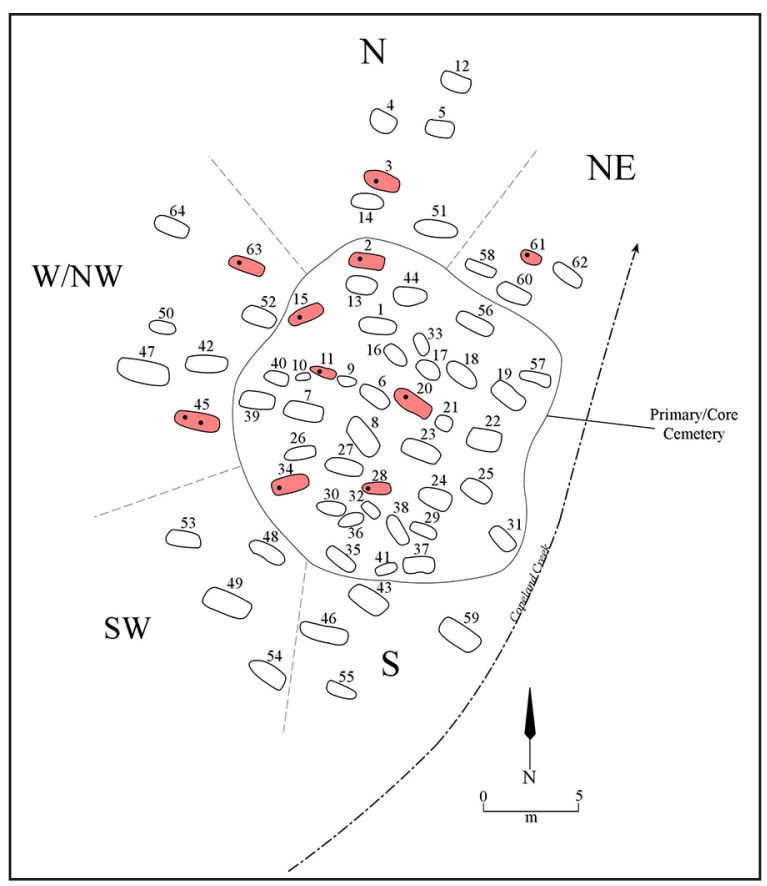

Figure 59. Burials with vessels that have multiple and different engraved panels on the same vessel. 


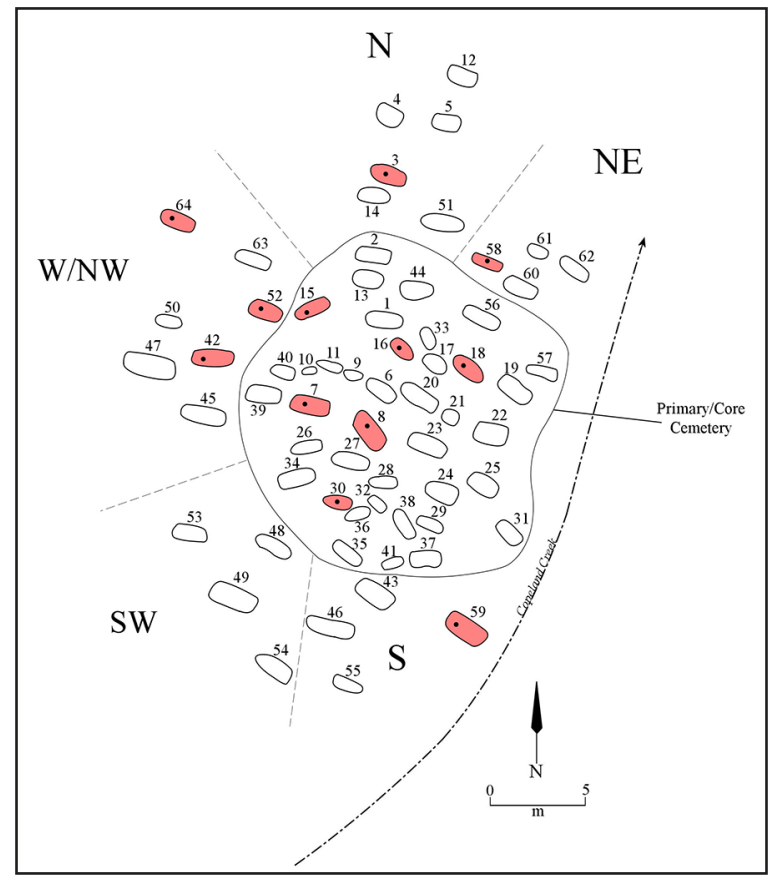

Figure 60. Burials with unidentified fine ware vessels in the H. R. Taylor cemetery.

Four other vessel forms and types are present in all of the cemetery areas, but are particularly common in the west/northwest section. These include vessels with inverted rims (Figure 61), extra-large jars (Figure 62), Ripley Engraved, var. Galt vessels (Figure 63), and Ripley Engraved, var. McKinney vessels (Figure 64). Ripley Engraved, var. McKinney carinated bowls are the most abundant ceramic type in the ceramic vessel funerary assemblage from the H. R. Taylor site.

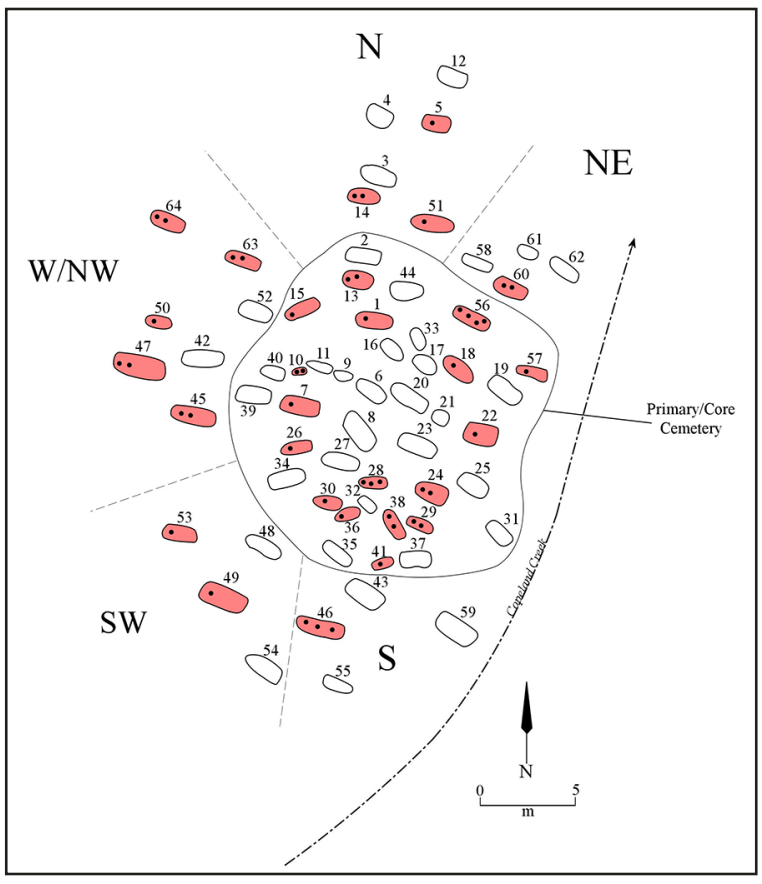

Figure 61. Burials with inverted rim vessels in the H. R. Taylor cemetery.

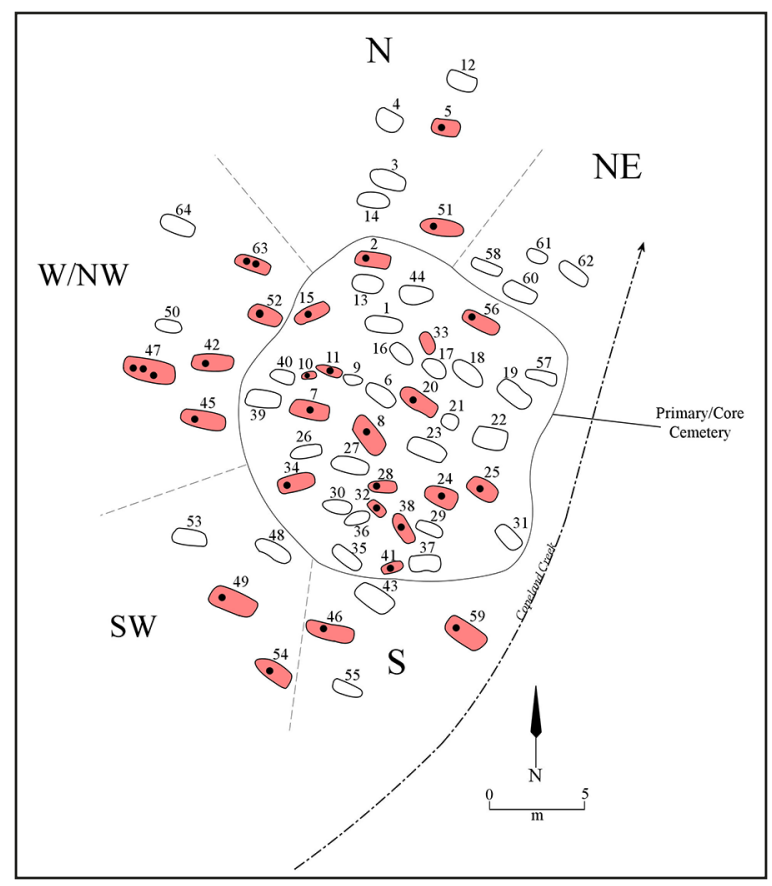

Figure 62. Burials with extra-large jars in the H. R. Taylor cemetery. 


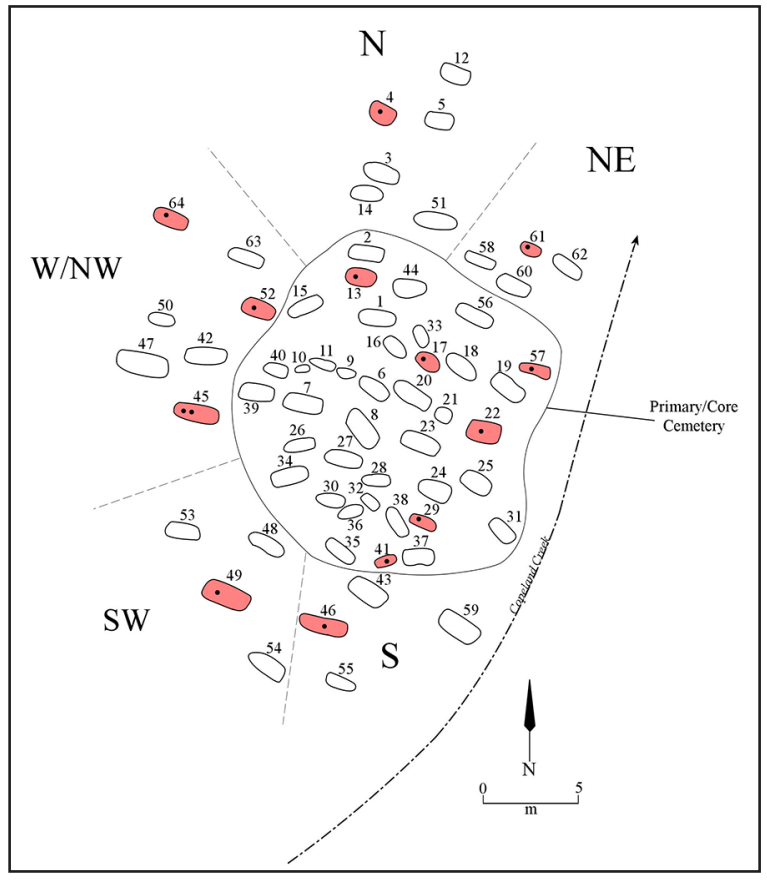

Figure 63. Burials with Ripley Engraved, var. Galt vessels in the H. R. Taylor cemetery.

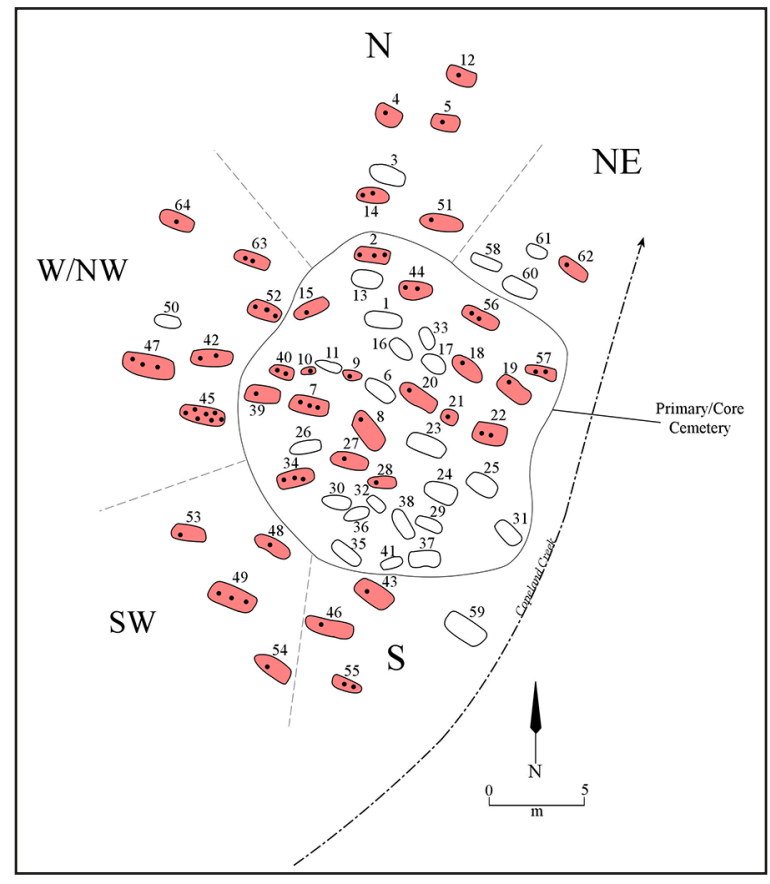

Figure 64. Burials with Ripley Engraved, var. McKinney vessels in the H. R. Taylor cemetery.

\section{Conclusions}

The distribution of a wide variety of funerary offerings in the burial features at the H. R. Taylor site, in combination with distinctive documented burial treatments (i.e., placement of a distinctive sand fill on the burial floor and evidence of fire in burial pits), are indicative of the continued use and expansion of the cemetery through ca. 80 years (ca. A.D. 1600-1680) for the burial of elite persons and commoners of a specific ancestral Caddo community in the Big Cypress Creek basin. While certain funerary offerings are present in all areas of the cemetery -including burials with more than nine vessels; extra-large utility ware jars; vessels with a rounded base; vessels (carinated bowls) with an inverted rim; Ripley Engraved carinated bowls; Ripley Engraved, var. Galt vessels; Ripley Engraved, var. McKinney vessels; Ripley Engraved, var. Pilgrims vessels; Taylor Engraved, var. Taylor carinated bowls; Taylor Engraved, var. Copeland bottles; Wilder Engraved bottles; the use of a white clay pigment on engraved vessels; and Talco arrow points - each part of the cemetery has a distinctive array of funerary offerings and/or burial treatments (see Table 13), emphasizing just how diverse were the choices for the number and range of funerary offerings in the community.

Finally, the distribution of the different identified varieties of Ripley Engraved also suggests that each variety continued to be made throughout the use of the cemetery, but that Ripley Engraved, var. McKinney variety remained the most popular style. Finally, the occurrence of Keno Trailed and Patton Engraved vessels, most commonly made and used after ca. A.D. 1680 in East Texas Caddo sites, only in the south and west/northwest sections, strongly suggest that the latest expansion of the H. R. Taylor cemetery was into these two sections. 


\section{Acknowledgments}

Thanks to the staff at the Texas Archeological Research Laboratory at The University of Texas at Austin (TARL) for their assistance in accessing and studying the vessel collection from the H. R. Taylor site, especially Marybeth Tomka and Lauren Bussiere. Jean Hughes of TARL also provided a number of scanned photographs, and other scanned photographs and negatives were provided by Julian A. Sitters and an intern of Lauren Bussiere's. Lance Trask and Sandra Hannum prepared the figures in this article. Thanks also to Julian A. Sitters for his assistance in compiling information on the Taylor vessels as part of the East Texas Caddo vessel database project, and for assisting one day in the documentation of vessels from the site.

\section{References Cited}

Eckert, S. L., K. L. Schleher, and W. D. James

2015 Communities of identity, communities of practice: Understanding Santa Fe black-on-white pottery in the Espanola Basin of New Mexico. Journal of Archaeological Science 63:1-12.

Fields, R. C. and E. F. Gadus

2012 Archeology of the Nadaco Caddo: The View from the Pine Tree Mound Site (41HS15), Harrison County, Texas. Reports of Investigations No. 164. 2 Vols. Prewitt and Associates, Inc., Austin.

Fields, R. C., V. L. Hatfield, D. Burden, E. F. Gadus, M. C. Wilder, and K. W. Kibler

2014 Testing and Data Recovery Excavations at 11 Native American Archeological Sites along the U.S. Highway 271 Mount Pleasant Relief Route, Titus County, Texas. 2 Vols. Reports of Investigations No. 168. Prewitt and Associates, Inc., Austin.

Gonzalez, B.

2005 Caddo tribal religious burial ceremonies beyond archeology. In A Rediscovering of Caddo Heritage: The W. T. Scott Collection at the American Museum of Natural History and Other Caddo Collections from Arkansas and Louisiana, by B. Gonzalez, R. L. Cast, T. K. Perttula, and B. Nelson, pp. 55-59. Historic Preservation Program, Caddo Nation of Oklahoma, Binger.

Hart, J. P. and T. K. Perttula

2010 The Washington Square Mound Site and a Southeastern Ceremonial Complex Style Zone among the Caddo of Northeastern Texas. Midcontinental Journal of Archaeology 35(2):199-228.

Lankford, G. E.

1992 Red and White: Some Reflections on Southern Symbolism. Southern Folklore 50(1):53-80.

Pearce, J. E. and A. T. Jackson

1931 Notes on Field Work, H. R. Taylor Farm, Harrison County, Texas, June 28, 1931 to July 22, 1931. MS on file, Texas Archeological Research Laboratory, The University of Texas at Austin.

Perttula, T. K.

1992 "The Caddo Nation": Archaeological \& Ethnohistoric Perspectives. University of Texas Press, Austin.

2007 Inverted Rim Engraved Vessels in Protohistoric and Early Historic Caddo Sites in Parts of Northeast Texas. Journal of Northeast Texas Archaeology 26:136-144.

2011 The Ceramic Artifacts from the Lang Pasture Site (41AN38) and the Place of the Site within an Upper Neches River Basin Caddo Ceramic Tradition. In Archeological Investigations at the Lang Pasture Site (41AN38) in the Upper Neches River Basin of East Texas, assembled and edited by T. K. Perttula, D. B. Kelley, and R. A. Ricklis, pp. 145-320. Archeological Studies Program Report No. 129, Texas Department of Transportation, Environmental Affairs Division, Austin.

2012 The Character of Fifteenth-to Seventeenth-Century Caddo Communities in the Big Cypress Creek Basin of Northeast Texas. In The Archaeology of the Caddo, edited by T. K. Perttula and C. P. Walker, pp. 363-410. University of Nebraska Press, Lincoln. 
2015 Caddo Ceramic Vessels from the Goode Hunt (41CS23) and Clements (41CS25) Sites in the East Texas Pineywoods. Special Publication No. 42. Friends of Northeast Texas Archaeology, Austin and Pittsburg.

2016 Documentation of Early Caddo Period Ceramic Vessels from the George C. Davis Site on the Neches River in Cherokee County, East Texas. Journal of Northeast Texas Archaeology 64:25-79.

2017 The Use of Clay Pigments on Ceramic Vessel Sherds from the Hatchel Site (41BW3) and Comparisons to Ancestral East Texas Caddo Ceramic Vessel Assemblages. Journal of Northeast Texas Archaeology 73:95-103.

2018 Ceramic Vessels and Other Funerary Objects in the H. R. Taylor (41HS3) Cemetery, Harrison County, Texas. Special Publication No. 46. Friends of Northeast Texas Archaeology, Austin and Pittsburg.

Perttula, T. K., P. S. Marceaux, and B. Nelson

2012a Study of the Margaret Hinton Collection of Pottery Vessels from Northeast Texas Caddo Cemeteries. Archeological \& Environmental Consultants, LLC, Austin and Pittsburg.

Perttula, T. K., B. Nelson, and M. Walters

2012b Caddo Archaeology at the Henry Spencer Site (41UR315) in the Little Cypress Creek Basin of East Texas. Special Publication No. 20. Friends of Northeast Texas Archaeology, Austin and Pittsburg.

Perttula, T. K., M. Tate, H. Neff, J. W. Cogswell, M. D. Glascock, E. Skokan, S. Mulholland, R. Rogers, and B. Nelson

1998 Analysis of the Titus Phase Mortuary Assemblage at the Mockingbird Site, "Kahbakayammaahin" (41TT550). Document No. 970849. Espey, Huston \& Associates, Inc., Austin.

Perttula, T. K., M. B. Trubitt, and J. S. Girard

2012 The Use of Shell-Tempered Pottery in the Caddo Area of the Southeastern United States. Southeastern Archaeology 30(2):242-267.

Perttula, T. K., M. Walters, and B. Nelson

2012c Little Cypress Creek Basin Archaeology: Six Late Caddo Period Cemeteries in Upshur County, Texas. Special Publication No. 22. Friends of Northeast Texas Archaeology, Austin and Pittsburg.

2016 Caddo Ceramic Vessels from the T. M. Sanders Site (41LR2) on the Red River in Lamar County, Texas. Special Publication No. 41. Friends of Northeast Texas Archaeology, Austin and Pittsburg.

Perttula, T. K., M. Walters, B. Nelson, B. Gonzalez, and R. Cast, with a contribution by R. G. Franciscus

2010 Documentation of Associated and Unassociated Funerary Objects in the Stephen F. Austin State University Collections, Nacogdoches, Texas. Stephen F. Austin State University Press, Nacogdoches.

Perttula, T. K., M. Walters, K. Stingley, and T. Middlebrook

2017 Ceramic Vessels and Other Funerary Objects in the Titus Phase Cemetery at the Tuck Carpenter Site, Camp County, Texas. Special Publication No. 48. Friends of Northeast Texas Archaeology, Austin and Pittsburg.

Schambach, F. F. and J. E. Miller

1984 A Description and Analysis of the Ceramics. In Cedar Grove: An Interdisciplinary Investigation of a Late Caddo Farmstead in the Red River Valley, edited by N. L. Trubowitz, pp. 109-170. Research Series No. 23. Arkansas Archeological Survey, Fayetteville.

Selden, R. Z., Jr., T. K. Perttula, and D. L. Carlson

2014 INAA and the Provenance of Shell-Tempered Sherds in the Ancestral Caddo Region. Journal of Archaeological Science 47:113-120.

Suhm, D. A. and E. B. Jelks (editors)

1962 Handbook of Texas Archeology: Type Descriptions. Special Publication No. 1, Texas Archeological Society, and Bulletin No. 4, Texas Memorial Museum, Austin. 
Thurmond, J. P.

1990 Archeology of the Cypress Creek Drainage Basin, Northeastern Texas and Northwestern Louisiana. Studies in Archeology 5. Texas Archeological Research Laboratory, The University of Texas at Austin.

Turner, R. L., Jr.

1978 The Tuck Carpenter Site and Its Relation to Other Sites Within the Titus Focus. Bulletin of the Texas Archeological Society 49:1-110.

Worth, J. E.

2017 What's in a Phase? Disentangling Communities of Practice from Communities of Identity in Southeastern North America. In Forging Southeastern Identities: Social Archaeology, Ethnohistory, and Folklore of the Mississippian to Early Historic South, edited by G. A. Waselkov and M. T. Smith, pp. 117-156. University of Alabama Press, Tuscaloosa. 